\title{
Modern Small and Microcogeneration Systems-A Review
}

\author{
Marcin Wołowicz $^{1, *(\mathbb{D})}$, Piotr Kolasiński ${ }^{2}$ (D) and Krzysztof Badyda ${ }^{1}$ \\ 1 Faculty of Power and Aeronautical Engineering, Institute of Heat Engineering, Warsaw University of \\ Technology, 00-661 Warsaw, Poland; krzysztof.badyda@pw.edu.pl \\ 2 Department of Thermodynamics and Renewable Energy Sources, Faculty of Mechanical and Power \\ Engineering, Wrocław University of Science and Technology, 50-370 Wrocław, Poland; \\ piotr.kolasinski@pwr.edu.pl \\ * Correspondence: marcin.wolowicz@pw.edu.pl
}

check for

updates

Citation: Wołowicz, M.; Kolasiński, P.; Badyda, K. Modern Small and Microcogeneration Systems-A Review. Energies 2021, 14, 785. https://doi.org/10.3390/en14030785

Received: 20 December 2020

Accepted: 20 January 2021

Published: 2 February 2021

Publisher's Note: MDPI stays neutral with regard to jurisdictional claims in published maps and institutional affiliations.

Copyright: (c) 2021 by the authors. Licensee MDPI, Basel, Switzerland. This article is an open access article distributed under the terms and conditions of the Creative Commons Attribution (CC BY) license (https:/ / creativecommons.org/licenses/by/ $4.0 /)$.

\begin{abstract}
Small and micro energy sources are becoming increasingly important in the current environmental conditions. Especially, the production of electricity and heat in so-called cogeneration systems allows for significant primary energy savings thanks to their high generation efficiency (up to $90 \%$ ). This article provides an overview of the currently used and developed technologies applied in small and micro cogeneration systems i.e., Stirling engines, gas and steam microturbines, various types of volumetric expanders (vane, lobe, screw, piston, Wankel, gerotor) and fuel cells. Their basic features, power ranges and examples of implemented installations based on these technologies are presented in this paper.
\end{abstract}

Keywords: microturbine; stirling engine; fuel cell; expander; vane; lobe; screw; piston; Wankel; gerotor; microcogeneration; $\mathrm{CHP}$

\section{Introduction}

For several decades the continuous energy consumption growth has been observed globally. This trend is mainly caused by the growing energy needs of an increasing world population, life quality improvement and technological development. The social access to different energy receivers (e.g., household appliances, cars, electronic devices, etc.) and their availability is nowadays easier than before, which directly translates into increasing consumption of fuels, heat, electricity and chill. Research on the energy consumption forecasting and modelling its variations is proceeding by different agencies and researchers around the world [1]. Reported data show [1] that the global primary energy consumption (i.e., the energy contained in fuels and renewable energy sources which is then converted into electricity, heating and sanitary heat and chill) in 2020 was ca. $1.58 \times 10^{8} \mathrm{GWh}$. The forecast for 2050 [1] indicates that the global primary energy consumption will probably increase nearly by $50 \%$ up to ca. $2.64 \times 10^{8} \mathrm{GWh}$. It is expected that ca. $28 \%$ of this energy demand will be covered by renewable energy sources, $27 \%$ by petroleum products and other liquid fuels (including biofuels), $22 \%$ by natural gas, $29 \%$ by coal and $4 \%$ by nuclear energy. Reliable and highly efficient energy conversion devices and systems (additionally characterized by low emission of harmful substances into the environment) have to be applied to meet this constantly growing energy demand and at the same time fulfil the strict regulations related to the natural environment protection. Therefore, the research, design and optimization activities related to modern energy conversion systems should be focused on limiting the fossil fuels consumption and increasing the use of alternative energy sources or clean fuels (e.g., natural gas). Energy conversion systems can be classified by different criteria (e.g., by the operating principle, design, cost, etc.). One of the commonly applied classification criteria is the system power output. By this criterion, systems can be classified into large-power (1.5 MW and more), medium-power (500 kW-1.5 MW), smallpower (15 kW-500 kW) and micro power (up to $15 \mathrm{~kW}$ ). Large- and medium-power energy conversion systems (such as e.g., large steam power plants) are usually highly efficient 
and used for industrial energy generation (they are supplying cities, regions or countries). Small- and micro-power systems are mainly used in distributed energy systems or by individual prosumers. Currently, different research works are carried out on the development of modern energy conversion technologies. In the field of large-power energy conversion technologies new solutions (such as the International Thermonuclear Experimental Reactor, i.e., ITER [2]) are investigated. In addition to these emerging technologies, research is still proceeding on the design optimization and improving the conversion efficiency of traditionally used units (e.g., steam power plants [3] and combined cycle gas turbine, i.e., CCGT units [4]). In addition to activities aimed at large-power systems, important research works are proceeded on small- and micro-power units dedicated for application in distributed energy systems. For many years, one of the visible development trends in modern power sector has been pursuing the diversification of the energy systems [5-7] by supporting activities related to the implementation of energy clusters [8] and small energy conversion units. Therefore, much attention is now paid to research and development works on small and micro-power systems which can be used by individual energy recipients (e.g., apartments, houses, shops or small industrial plants) for covering their own energy needs. Nowadays special focus is paid on cogeneration systems. Cogeneration, i.e., Combined Heat and Power (CHP), is an important tool for achieving significant fuel savings and reduction of $\mathrm{CO}_{2}$ emissions. Compared to separate fossil fuel-based electricity and heat generation, fuel savings and corresponding $\mathrm{CO}_{2}$ reductions will often be in the order of $30 \%$. The $\mathrm{CO}_{2}$ reductions can sometimes be higher as a fuel conversion, e.g., from coal or oil to natural gas or biomass, can be taken into account. These benefits have been recognized by the European Commission and several initiatives have been taken to increase the use of cogeneration in the generation of heat and electricity.

Cogeneration is commonly used in large generating units-combined heat and power plants. However, there is a noticeable trend towards the use of cogeneration in smaller systems, especially those designed for local and distributed applications. Currently, there are several technologies used in micro-cogeneration such as small gas turbines, small steam turbines, Stirling engines, organic Rankine cycle systems (ORC systems) and fuel cells. Technological progress [9-12], as well as the general trend towards smaller generating units, resulted in an increased interest in small cogeneration units, hoping that they would be able to efficiently supply electricity and heat to individual facilities $[13,14]$. Small heat and power plants are usually based on internal combustion gas engines and are fully adapted to the needs of customers. They are characterized by high efficiency, thus providing cheaper energy, and they also allow for long-term cost planning. It should also be noted that such systems meet the strictest European environmental standards. The EU Cogeneration Directive defines micro-cogeneration as a unit featuring a maximum power of less than $50 \mathrm{kWe}$, while in Germany micro-cogeneration systems are treated as those that feature a power below $15 \mathrm{kWe}$. This is due to the following reasons: these systems are clearly intended for use in single family homes, apartment buildings, small businesses or hotels $[15,16]$. In the following part of this paper modern small and microcogeneration systems are reviewed, with special focus on the technologies utilizing energy sources of high-quality. The features and operating parameters of these systems are discussed together with their possible applications.

\section{Stirling Engines}

There has recently been an interest in using Stirling engines as electricity generators in domestic CHP systems. Many households, especially in Europe, use natural gas for heating. The natural gas burner is easily customizable to provide a heat source for a small 1 to $10 \mathrm{~kW}$ Stirling engine, sized to meet the electricity needs of a typical household or a small business unit. The engine then forms a part of a system in which the waste heat that first heats the Stirling cylinder head is then directed to domestic hot water distribution system and/or central heating system. Several commercial systems based on this type of engine are already commercially available. 


\subsection{Historical Background}

The Stirling engine was invented in 1816 by Robert Stirling in Scotland, some 80 years before the invention of the diesel engine, and enjoyed considerable commercial success until the early 20th century.

Before the Stirling engine was created, however, attempts were made to develop a hot air engine. The first hot air engine was the atmospheric fire-mill. It was an air engine in which heat was transformed in mechanical power. Its inventor was Guillaume Amontons [17-19], a Frenchman, who invented it in 1669. The engine proposed by Guillaume was a pistonless engine, and the air was heated and cooled in a closed circuit. Heat was supplied from external source (i.e., fossil fuel combustion chamber). The drawing of Guillaume engine is presented in Figure 1.

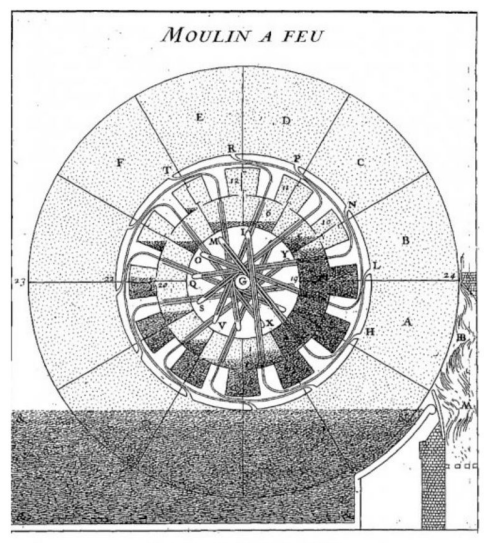

Amontons Fire Wheel - 1699

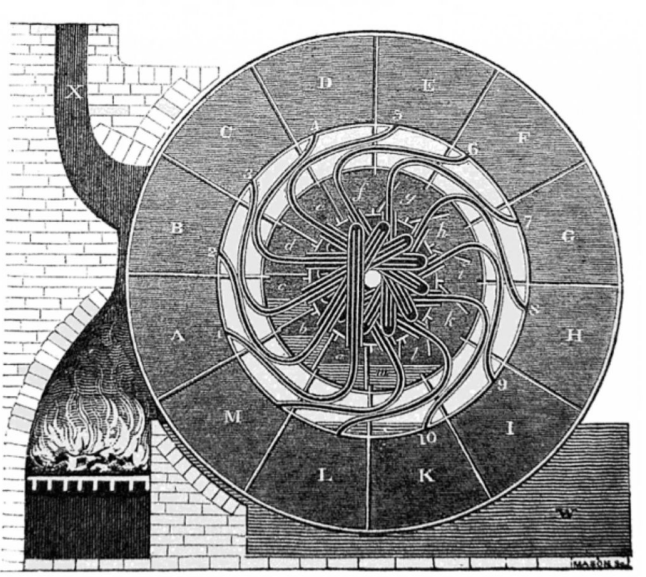

Figure 1. View on the Guillaume Amontons hot air engine [20].

Another example of a hot air engine is the engine proposed by Sir George Cayley [21,22]. It is considered to be the first hot air engine that worked successfully. Cayley has shown great ingenuity in overcoming the practical difficulties of high operating temperatures. This type of engine was one in which the fire is shielded and fed with air forced under the grate in an amount sufficient to maintain combustion, while by far the largest part of the air goes above the fire to be heated and expanded; the air with the combustion products then acts on the piston and passes through the operating cylinder, no metal heating surface is required, the heated air is brought into direct contact with the fire. One of these engines worked for many months for testing. It was better than any design of steam engine known at the time in terms of fuel economy compared to the power output. However, the joints were very troublesome, and the cylinder and piston seal were quickly destroyed by dust and gravel particles from the fuel, which acted as abrasive and prevented lubrication. An attempt was made to filter the air before entering the cylinder with sheets of wire mesh, 
but these either subsided or were soon choked and rendered useless [20]. The drawing of the Cayley engine is presented in Figure 2.

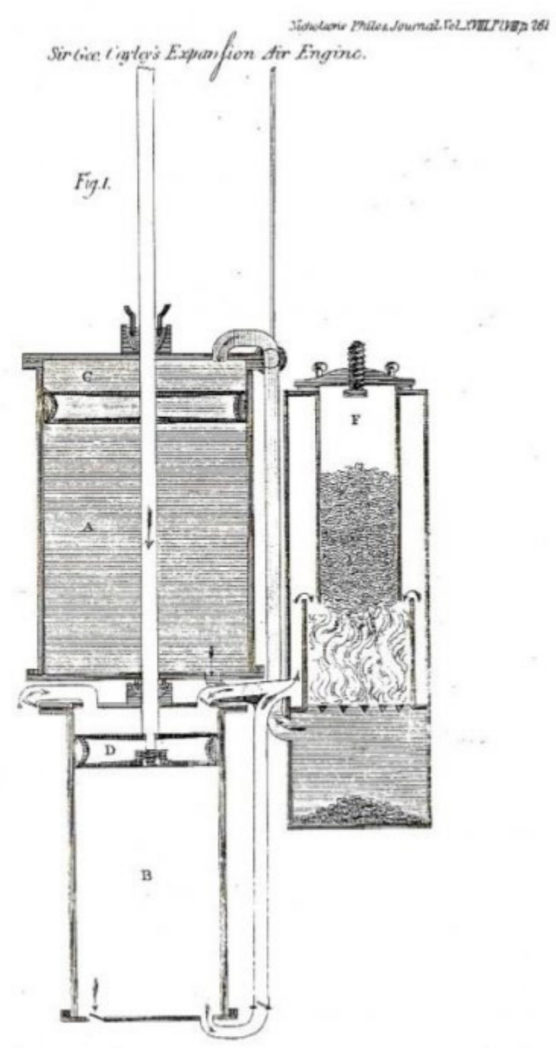

Figure 2. View on the Cayley hot air engine [20,23].

The Stirling engine was invented and patented in 1816 by Robert Stirling. It was originally used in Scotland, Ayrshire, in 1818 to drive a water pump. Unfortunately, due to the shortcomings of the materials at that time, the engine only worked for two years and was then replaced by a steam engine. In later years, Robert Stirling and his brother James improved the design by, among other changes, adding a second piston. The end result of these works was that the engine obtained a higher efficiency than steam engine, but unfortunately there were still problems with the materials, which caused users to return to steam engines. A view of Stirling's engine patent is presented in Figure 3.

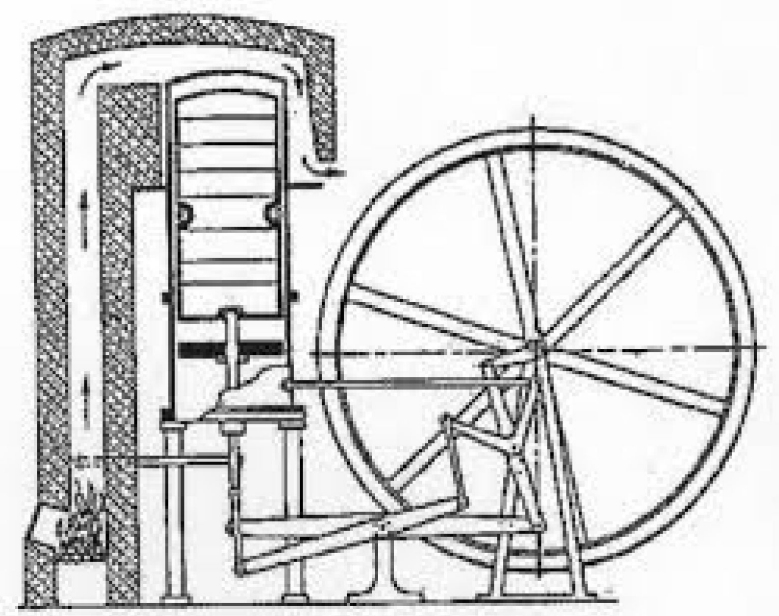

Figure 3. View of Stirling's engine patent drawing, 1816 [24]. 
Until the First World War, many other interesting concepts of using a hot air engine, e.g., for powering aircrafts, were created, but they were not widely used. These engines were mainly used in small workshops and for driving water pumps because, unlike a steam engine, they did not require a qualified engineer to operate them. Unfortunately, their power and efficiency remained low compared to their size [25-27].

The renaissance of interest in the Stirling engine took place in the interwar period thanks to the concern of the Dutch Philips, who was looking for a simple, light engine for powering a radio. Thanks to the invention of steel resistant to high temperatures after the First World War and its application in the Stirling engine, it was possible to reduce the failure rate. At that time, Stirling engines sometimes had an efficiency of less than $1 \%$ (while theoretically they could achieve an efficiency of $60 \%$ ). Professor Holst believed in this possibility when he started his research on the Stirling engine. Unfortunately, the German occupation during the Second World War significantly inhibited this research. However, in 1947, after ten years of development, a small 30-horsepower engine was presented, featuring a rotational speed of $3000 \mathrm{rpm}$ and efficiency similar to internal combustion engine. Another result of this work was a small engine that ran for over $2000 \mathrm{~h}$ without any visible damage. The important direction of research on Stirling machine design was also the Stirling cooler based on reversed engine cycle, which application gave the opportunity of obtaining of very low temperatures. Initially, the obtained temperature was around $-190{ }^{\circ} \mathrm{C}$, but in later years even the temperature of $-260{ }^{\circ} \mathrm{C}$ was achieved. However, the main goal of Philips, who was creating a small power source, has not been achieved despite the use of solutions such as the diamond-shaped mechanism [28].

In late 1950s, Philips engines achieved an efficiency of about 38\%, which was higher than the efficiency achieved by the gasoline and diesel engines. In 1958, the automotive concern General Motors was interested in these works, looking for a new type of propulsion in the automotive industry, as well as for powering generators and submarines. The result was a developed prototype of $150 \mathrm{hp}$ Rinia engine [29]. However General Motors senior management decided to abandon the program before the engine was put into production. The Stirling engine concept was revisited at the turn of the 1960s and 1970s, mainly due to the rising oil prices. The first prototypes of buses powered by Stirling engines were then created, but putting this type of bus into production after the end of the oil crisis was found unprofitable. As a curiosity, it is worthy to mention that Stirling engines have had a significant impact on the design of today's conventional submarines. Thanks to application of the Stirling engine, it was possible to extend the time they can be submerged. The first class of submarines in which the Stirling engine is applied for propulsion is the Swedish project A-19 Gotland, equipped with two Stirling engines. Thanks to their application, the ship can stay fully submerged for 2 weeks and travel at a speed of 5 knots. The efficiency of these engines is ca. $40 \%$. Nowadays, in addition to the above-mentioned applications, the possibility of using Stirling engines in thermal energy and renewable energy for electricity production is also considered [30].

Some engine companies, such as MAN-MWM, United Stirling of Sweden, and Ford Motor Company of Detroit, have started research programs to develop Stirling engines for automotive applications. To date, few multi-cylinder Stirling engines featuring different power ranges have been prototyped by these companies. The thermal efficiency of Stirling engines designed for automotive applications is higher than $40 \%$. The main design and application problem that needs to be solved in the future is the high weight and large size of such an engine [31-33].

\subsection{Functional Description}

A Stirling engine $[27,34,35]$ is an external combustion reciprocating engine that uses one or more pistons to achieve useful operation by supplying heat from an external source. They differ significantly from the internal combustion engines found in most vehicles. Stirling engines use the same gas during operation, as opposed to internal combustion engines which constantly take in and discharge gas (they take the air-fuel mixture and 
discharge the exhaust gases). In addition, Stirling engines do not use the combustion effect inside the chamber as is the case of conventional internal combustion engines, which makes their operation very quiet.

A key unique feature of Stirling engines is that there is a constant amount of gas inside the cylinders. The gas pressure can be regulated by supplying or receiving heat, i.e., thanks to the changes in gas volume. Thanks to the supplied heat pressure and increasing temperature of the gas contained in the cylinders, on the contrary, removing heat form cylinders reduces pressure and temperature. By changing the way these two processes are performed engine deliver useful work. The engine operates according to the "Stirling cycle" described below [28,35]. The operation cycle is organized as follows:

- heating and expansion-heat is supplied from an external source, raising the gas temperature and thus the pressure. This causes the piston to slide and provides useful work;

- $\quad$ flow and cooling-the piston moves to force gas into another cylinder where it is cooled. Cooling the gas allows for easier compression, meaning less work is required to proceed this process than in step 1;

- compression-the gas is compressed and the excess heat resulting from compression is removed via the cooling source;

- reverse flow and heating-the pressurized gas returns to the starting cylinder and the cycle repeats.

The principle of the Stirling engine operation and its basic components are shown in Figure 4.

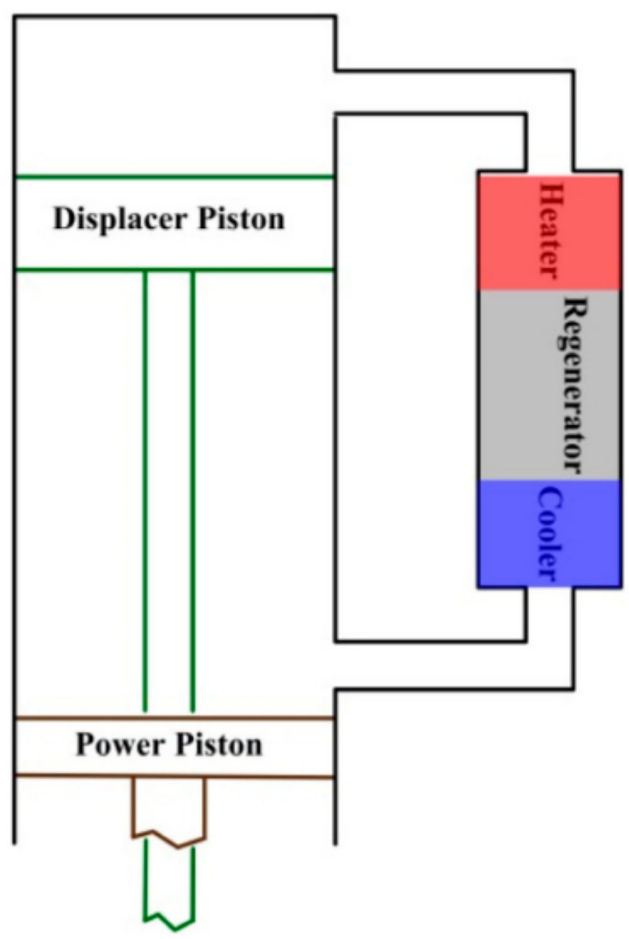

Figure 4. Example schematic diagram of a free-piston Stirling cycle engine with a linear alternator for energy extraction [36].

Heat transport in the Stirling engine is realized by a displacer piston. There is more gas in the working chamber on the hot side of the engine when the displacer piston is closer to the bottom dead center. When the heat is supplied to cylinder from the heat source the gas pressure inside the engine also increases. When the displacer is closer to the top dead center, the gas pressure drops and most of the gas is cooled. An additional effect is the movement of the power piston which interacts directly with the displacement element. By 
balancing the area and masses of the pistons, the dynamics of the pistons movement, and the restriction of mass flow from one side of piston to the other, a self-sustained cycle can be achieved to convert the heat absorbed by the engine into useful work [36].

To increase efficiency, most Stirling engines use a regenerative heat exchanger, simply referred as to "regenerator". A regenerator works like a thermal condenser in which heat is absorbed and released from the gas as it passes from one cylinder to another. This heat transfer takes place cyclically. This cyclicality corresponds to the operating frequency of the engine. The regenerator is clearly visible in Figure 5, which shows a block diagram of the operation of a Stirling engine [36-38].

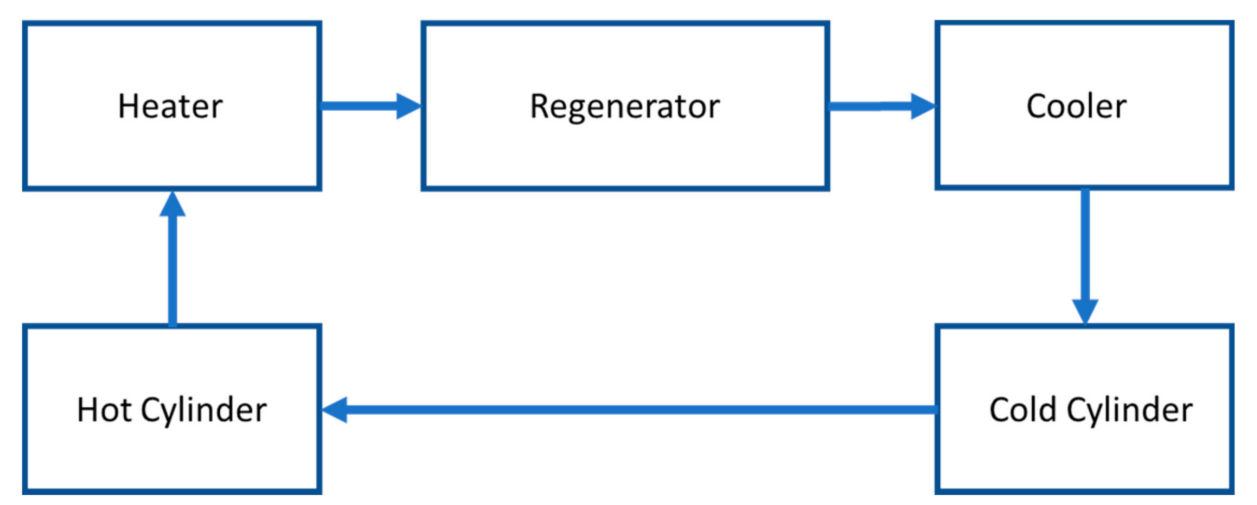

Figure 5. Block diagram showing working fluid flow in the Stirling engine and its main components.

\subsection{Stirling Engine Designs}

Stirling engines can have many different designs. Three classic designs are described in the following. An alpha-type engine has two cylinders in which two pistons move. Pistons are loaded on the one hand with a variable pressure of the working gas, and on the other hand with a constant gas pressure prevailing in the so-called buffer space. The phase shift (between $85^{\circ}$ and $120^{\circ}$ ) of the pistons is required. It is important that when assembling this type of engine, the structural and kinematic elements of the working mechanism and engine block are so arranged that the piston working in the hot cylinder is shifted in phase ahead to the piston moving in the cold cylinder. More details about the alpha-type Stirling engine can be found in [37,39-46].

The beta-type design [47-54] has one cylinder in which two pistons move coaxially with the required phase shift. The upper piston moves in the cylinder, forcing the gas twice in circulation between the compression and expansion chamber through a set of heat exchangers. As a result, the engine is only loaded by the pressure difference resulting from the gas flow through the heat exchangers and through the resistances. The group of heat exchangers is connected to the compression and expansion chamber, and the buffer space is located under the piston. The movement of the lower piston, which is phase-lagged, compresses and decompresses the gas.

The gamma-type design is the simplest and easiest to manufacture of the Stirling engines. Similar to the beta design, the gamma design has two cylinders (sometimes the diameter of one cylinder is larger and diameter of the other is smaller). Cylinders are connected by channels to the built-in set of heat exchangers. A more detailed description of the gamma-type Stirling engine's application, as well as results of its operation modeling is presented in [55-64]. Starting this type of engine can be proceeded with smaller heat input, compared to the alpha and beta designs. Schemes of alfa, beta and gamma Stirling engines are presented in Figure 6. 


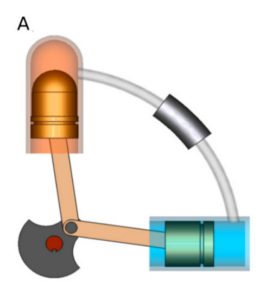

D

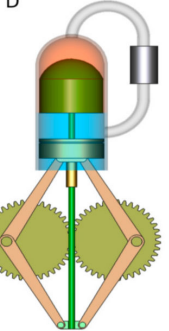

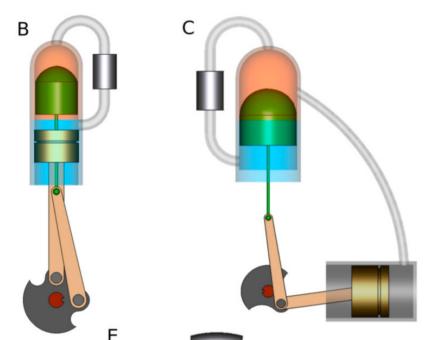

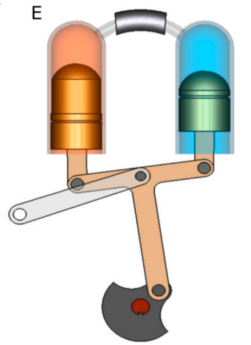

Figure 6. Alpha, beta and gamma configuration of a Stirling engine. (A) alpha configuration with crank drive; (B) beta configuration with crank drive; (C) gamma configuration with crank drive; (D) beta configuration with a rhombic drive replacing the crank drive; (E) alpha configuration with Ross yoke instead of a crank drive [65].

\subsection{Stirling Engine Applications}

At the beginning of the 19th century, as a result of the rapid development of internal combustion engines and electrical machines, the further development of Stirling engines was severely impeded. However, due to the high thermal efficiency, quiet operation and the ability of Stirling engines to use multiple fuels, it meets today's requirements related to energy efficiency and environmental protection. Cogeneration units based on a Stirling engine are considered to be one of the best among the low power range electricity generation units.

Stirling engines are built in a fairly large power range. These units can have a power of a few watts to over $1 \mathrm{MW}$, but the most popular are those for single $\mathrm{kW}$. Stirling engines are a viable alternative to currently used heat engines. The main barrier to the development of this technology is the presence on the market of competitive solutions in the form of well-developed classic technologies.

Microgen is a leader in the production of small Stirling engines. It offers engines with a capacity of several kilowatts. An example of a Stirling engine manufactured by Microgen is shown in Figure 7.

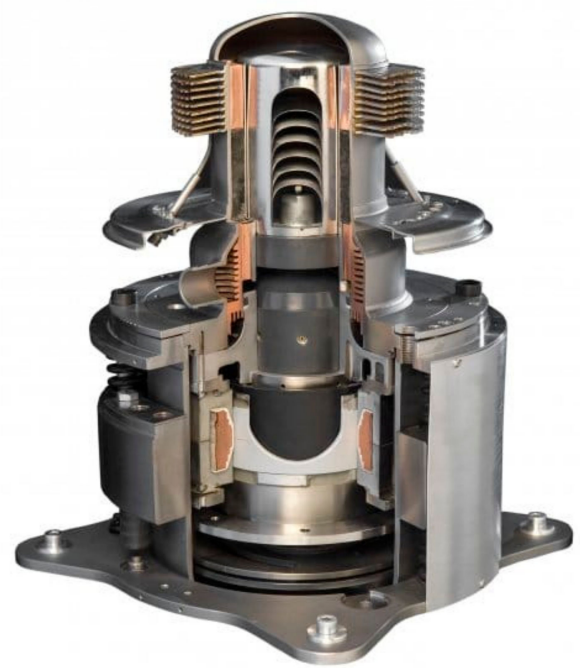

Figure 7. View on the Stirling engine made by Microgen [66,67]. 
Stirling engines are used in micro-cogeneration mainly due to the nature of their construction, i.e., their operation requires an upper and lower heat source [67-75]. However, the source from which this heat comes is not significant. This means that these engines can operate with virtually any fuel. The most popular microcogeneration systems found today are those based on gas fuel.

An example of such systems based on gas fuel are the systems of the German company Viessmann. These systems are known under trade names Vitotwin 350-F and Vitotwin 300-W. Their view is shown in Figure 8.
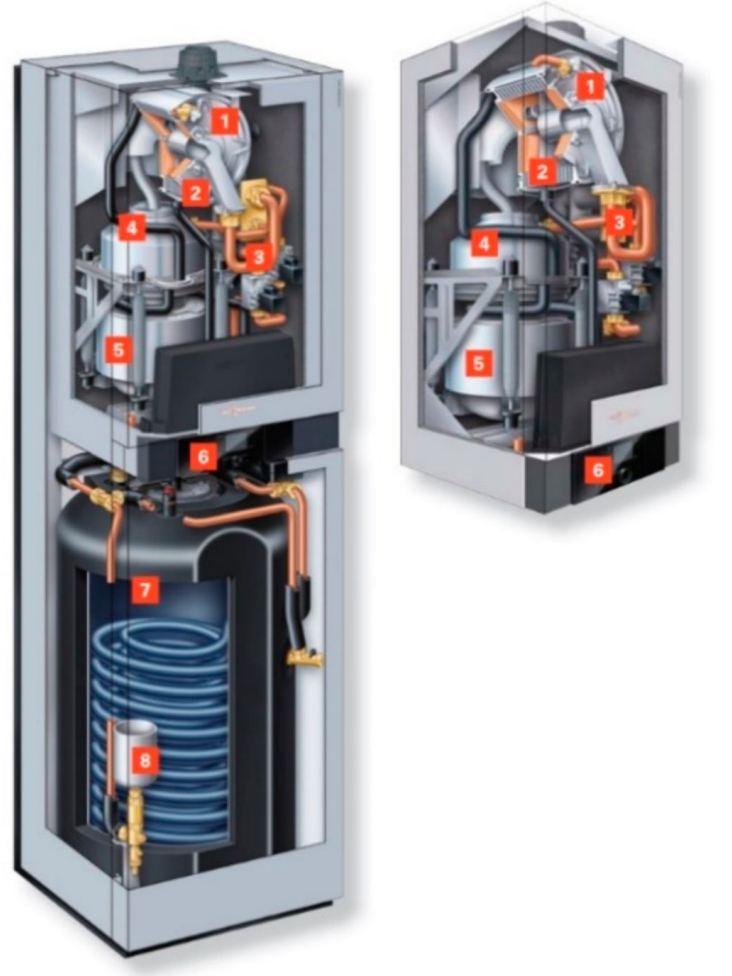

Figure 8. Combined Heat and Power (CHP) system based on a Stirling engine made by Viessmann [76,77]. 1-peak gas burner, 2-stainless steel heat exchanger, 3-valve dosing air supplied to the burner, 4 - ring gas burner to feed the Stirling engine, 5-Stirling engine, 6-control panel, 7-hot water buffer tank, 8-vessel for pressure equalization.

Viessmann cogeneration modules can be used in almost any facility, e.g., in residential houses, office buildings, industrial plants and local district heating networks.

The Vitotwin 300-W micro cogeneration system with an electrical output of $1 \mathrm{~kW}$ and a thermal output of $26 \mathrm{~kW}$ is a real alternative to conventional heating systems in singleand two-family houses. It works particularly efficiently with an annual gas consumption of at least 20,000 kWh and an electricity consumption of over $3000 \mathrm{kWh}$. As heat is constantly generated during operation, a combination with a heating water buffer cylinder is required. The storage tank can be installed in devices that only need $0.36 \mathrm{~m}^{2}$ of floor space to be installed, such as the Vitotwin 350-F.

Compact micro-cogeneration systems with an integrated condensing boiler can be a self-sufficient source of heat and electricity for a household. The Stirling engine in the Vitotwin can work with power modulation in the range of 0.3 to $1 \mathrm{~kW}$ of electrical power and requires virtually no maintenance. The electricity generated this way covers the basic demand of the building, correspondingly reducing the consumption of electricity from the power grid and contributing to savings.

Increased demand for electricity at home can be signaled to the micro-cogeneration system using the function of producing electricity on demand. This function is activated by 
the timer or by a button on the maintenance-free remote control or by means of a wireless socket. This way, electricity can be generated during greater demand for it, e.g., during washing and cooking. Lower the consumption of electricity from the grid will be, the more electricity will be produced by the micro-cogeneration device. An exemplary installation diagram is shown in Figure 9.

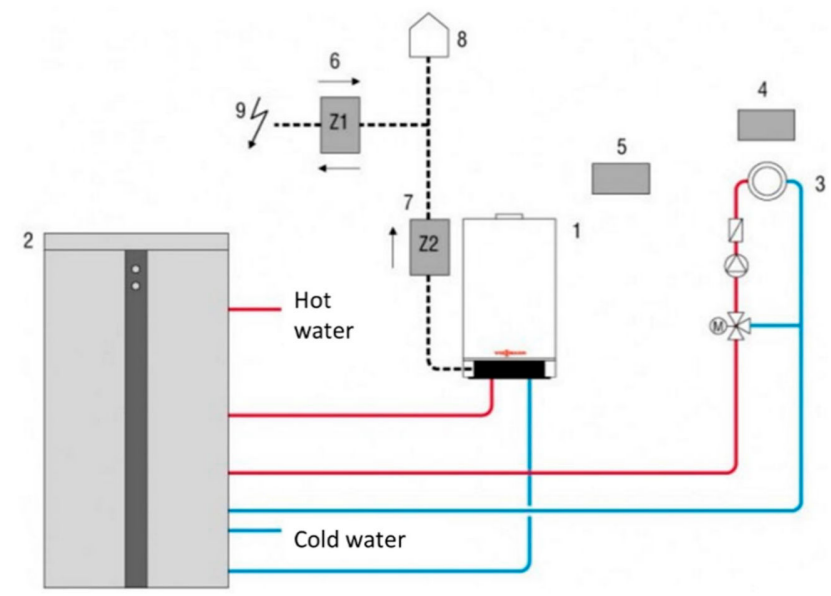

Figure 9. An exemplary installation diagram with CHP system Vitotwin [77]. 1-Vitotwnin 300-W microcogeneration unit, 2-heating water buffer cylinder with built-in domestic hot water heaterVitocall 340-M with a capacity of 400 L, 3-heating installation, 4-wireless remote control module, 5-monitoring device-remote control, 6-bidirectional meter, 7-meter of produced electricity (installed in the Vitotwin system), 8-home electrical network, 9-external power grid.

Thanks to the aforementioned advantage of the Stirling engine, i.e., the possibility of cooperation with any heat source, microcogeneration systems powered by solid fuel were created. Such a system was implemented by Okofen, which offered a Pellematic biomass boiler with an integrated Stirling engine on the market. The view of such a set is shown in Figure 10. The Stirling engine is located partially outside, while the engine head is located inside the biomass boiler.

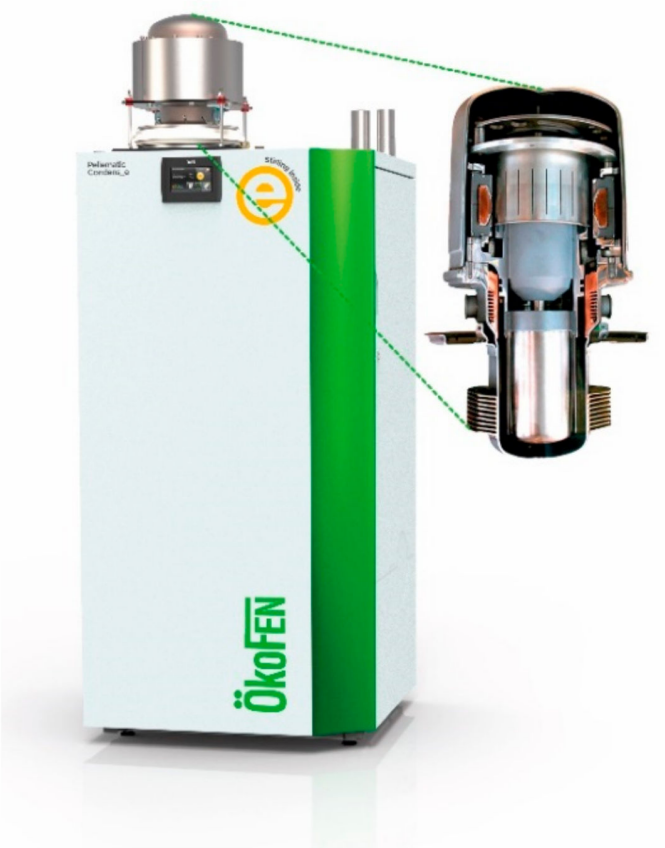

Figure 10. View of the Okofen biomass boiler coupled with a Microgen Stirling engine $[77,78]$. 
A major problem in microcogeneration systems with a Stirling engine is the transfer of heat generated in the combustion process to the engine head. Manufacturers of engines as well as boilers and burners are still carrying out optimization work in order to better receive heat by the Stirling engine head. Various methods are used, such as ribbing. This problem does not arise in the case of gaseous fuel systems, since the configuration of the burner can be adapted to the shape of the head of the engine. Stirling engine heads adapted to receive heat from solid fuel systems are intensively developed by means of advanced numerical analyses. The example of the concept Stirling engine with an additional heat exchanger located at an angle of $45^{\circ}$, designed specifically for the system analyzed by the authors $[79,80]$ is shown in Figure 11. The manufactured engine based on this design is shown in Figure 12.

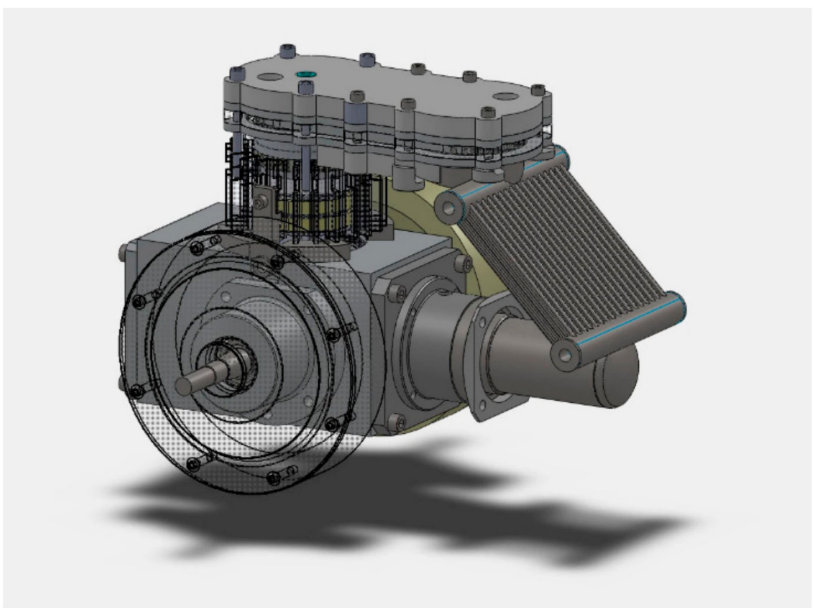

Figure 11. Visualization of a Stirling engine with an additional heat exchanger attached to work with a solid fuel boiler $[79,80]$.

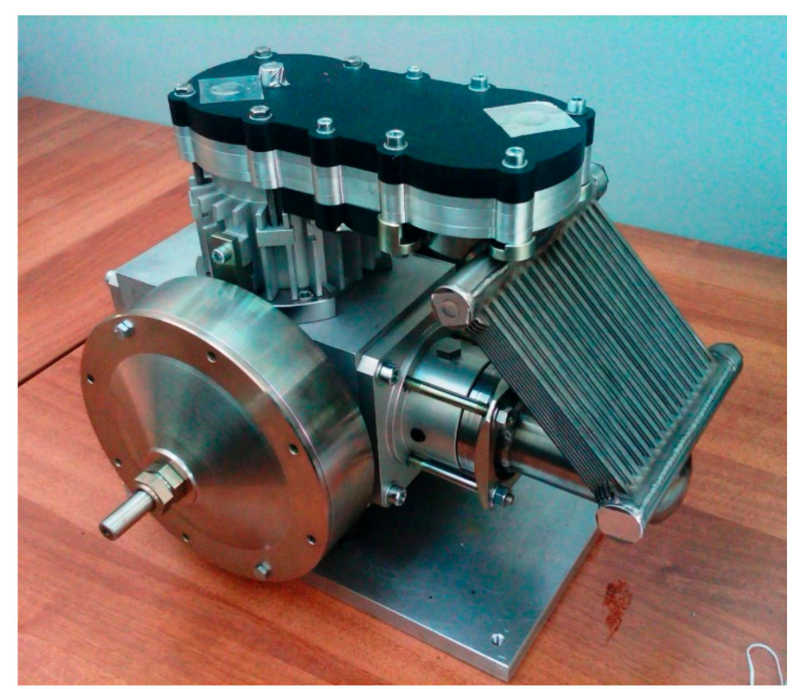

Figure 12. Manufactured Stirling engine with an additional heat exchanger attached for operation with a solid fuel boiler $[79,80]$.

The views on the heat exchanger which was designed specifically for this system, are presented in Figures 13 and 14. 


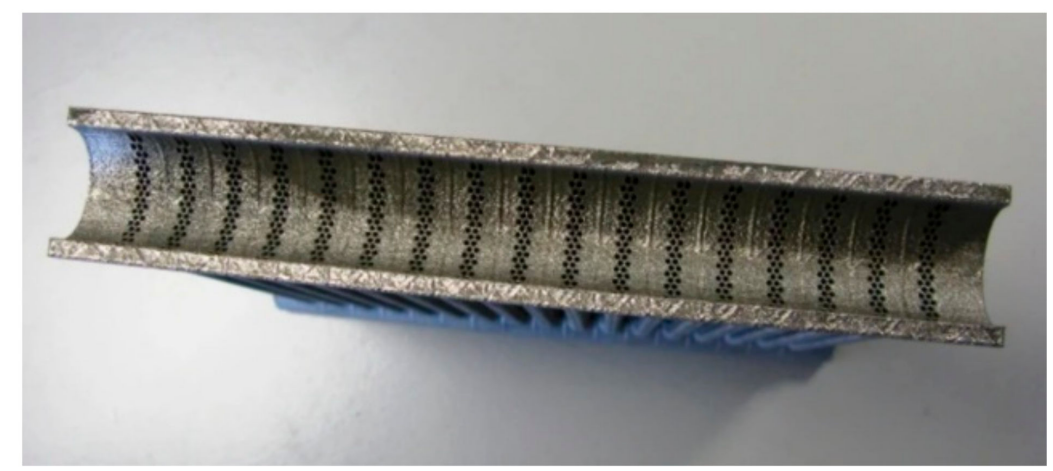

Figure 13. Side view of a heat exchanger adapted to operate with a Stirling engine and a solid fuel system [80].
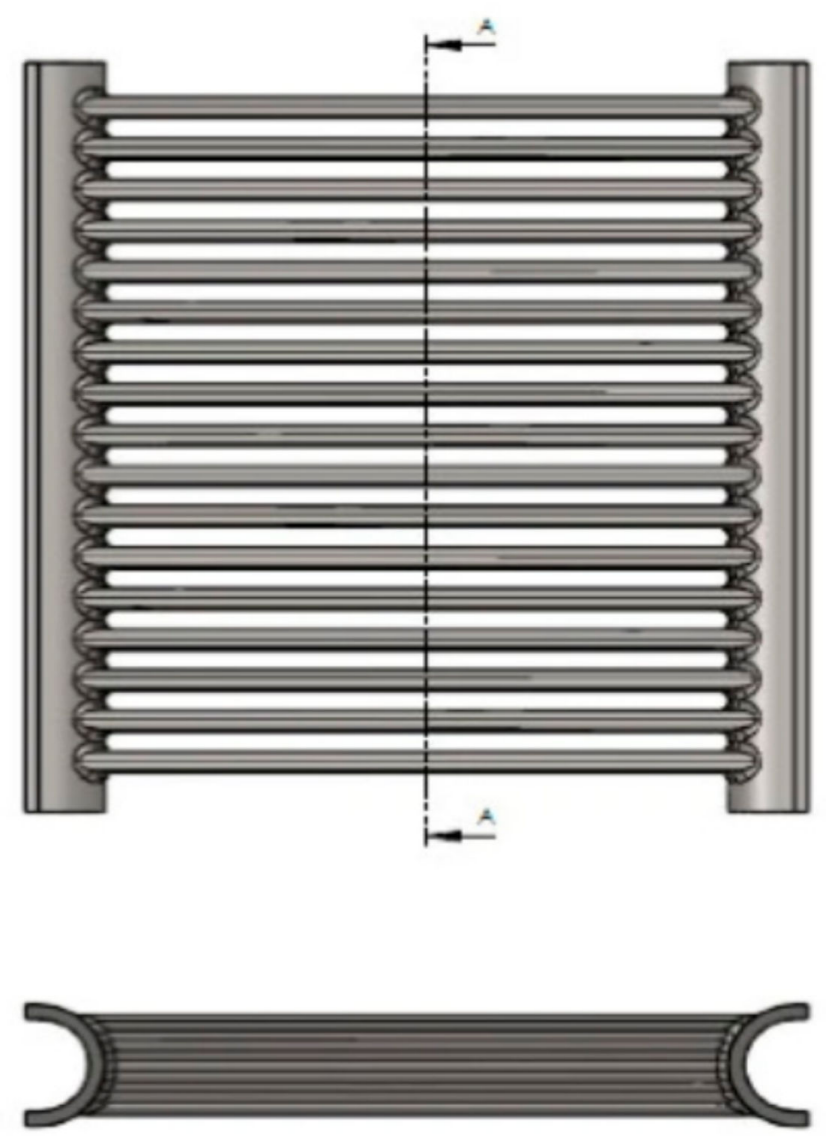

Figure 14. A view of a specially designed exchanger for the operation of a Stirling engine with a solid fuel system [80].

A scheme of the micro-cogeneration system with the previously presented heat exchanger collecting heat from the exhaust gases and transmitting it to the Stirling engine head is shown in Figure 15. Sample temperatures at characteristic points of the system are plotted. The heat exchanger of the Stirling engine located at an angle of $45^{\circ}$ in the combustion chamber of the boiler can be also noticed. 


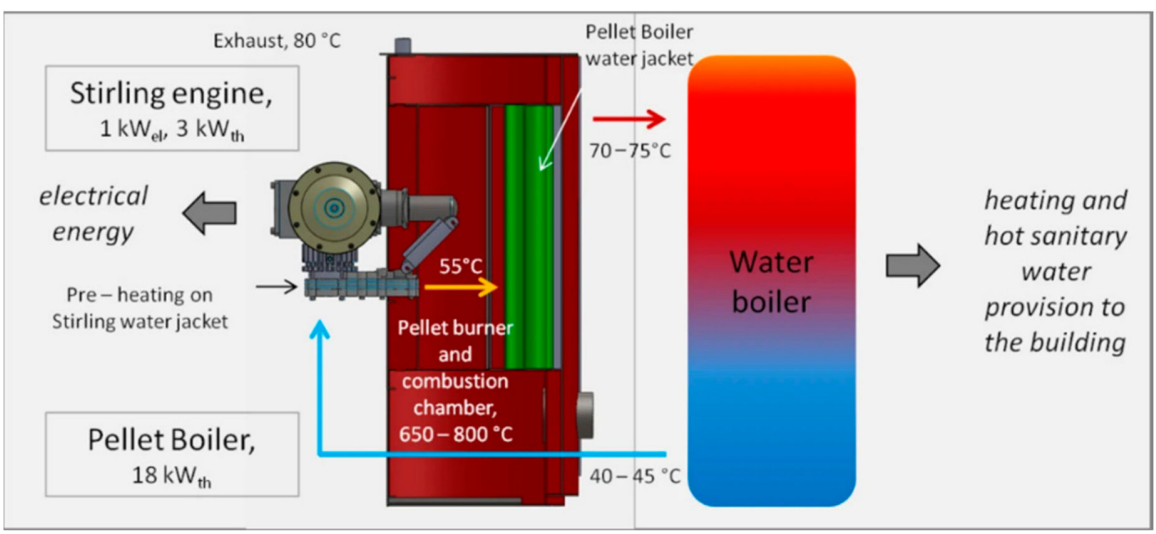

Figure 15. View of the cogeneration system with a Stirling engine with a visible heat exchanger [80].

Another example of a heat exchanger cooperating with a Stirling engine head is presented in Figure 16. This heat exchanger was designed at West Virginia University, Morgantown, USA [81,82]. The concept of this exchanger differs from the previous one mainly in shape. It features toroidal design, which is the most common design of Stirling engine heads.
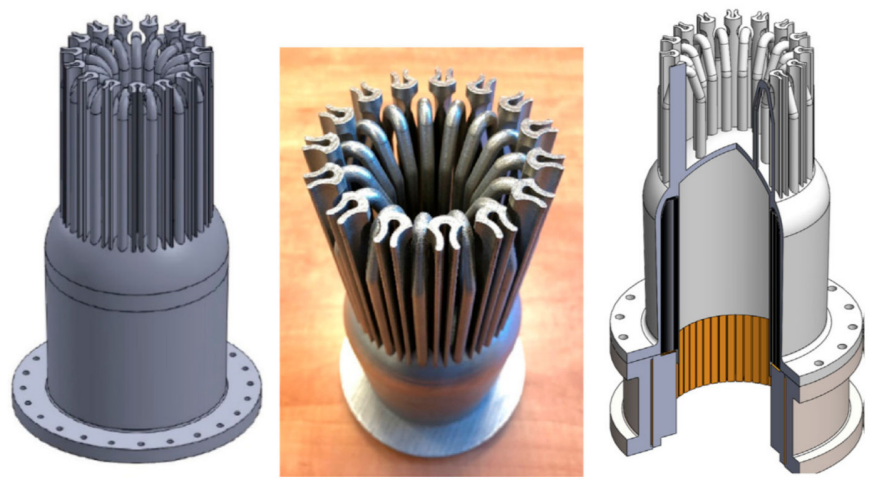

Figure 16. View of the Stirling engine head designed for operation with a solid fuel boiler $[77,81]$.

The aforementioned Microgen company, as a leading manufacturer of small Stirling engines in the world, has developed different types of heads dedicated to Stirling engines. However, their design is kept confidential and not widely published. The example of $1 \mathrm{~kW}$ engine head implemented by Microgen company is presented in Figure 17.

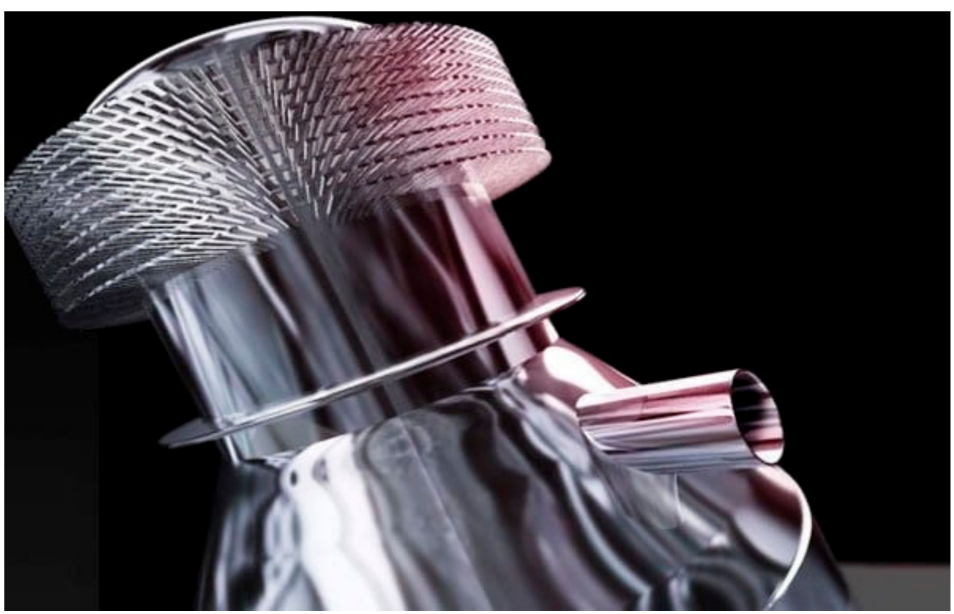

Figure 17. View of the Stirling engine head designed by Microgen $[66,77]$. 
Stirling engines can be used in many industries and domestic applications. First of all, they can be used as small cogeneration systems for the needs of domestic [83-85] customers and for industrial purposes [86-91]. Due to the development of renewable energy, especially wind and solar, Stirling engines have found application in solar power plants [92-99]. Another sector where they are used is the refrigeration sector [100-108]. They are an alternative to the commonly used compressor systems. The helium used as a working medium is safe in terms of toxicity and flammability.

\subsection{Summary}

The Stirling engine has the unquestionable advantage of being able to work with any heat source. It can be powered by heat obtained, for example, from the combustion of biomass or other solid fuel source. However, as mentioned in this article, there are technological problems, primarily in the process of efficient heat transfer from its source to the engine head. For this reason, among microcogeneration systems utilizing Stirling engines those fed by natural gas are much more popular. The challenge of better designing of solid fuel-based systems may be perspective. There are many areas of world (such as the countries of far Asia) where there is a shortage of gaseous fuel, while solid fuels are widely and cheaply available. Today's Stirling engines are refined and virtually maintenance-free units. They do not generate vibrations or noise.

The application of a Stirling engine as part of a small CHP system also has some disadvantages. The production of electricity is closely related to the production of heat, while the demand for electricity and the demand for heat often do not coincide. Therefore, there may be an overproduction of electricity or an insufficient amount of it. It is therefore necessary to verify contracts with electricity suppliers in terms of contracted power as well as to enable the opportunity for sale of excess, not consumed, electricity generated by the Stirling engine. This can be done through two-way electricity meters and appropriate contracts with the operator of the distribution grid. For example, Polish regulations allow electricity to be fed into the grid and treated as an energy storage. Unfortunately, for such a service there is a fee in the form of $20 \%$ of the delivered energy. This means that the excess of produced electricity can be "pumped" to the grid at any time and $80 \%$ of it can be taken back at any time. It should be noted that this regulation applies to installations featuring a maximum power of $10 \mathrm{~kW}$ (for larger installations the percentage increases up to $40 \%$ ) and utilizing renewable energy sources. Thus, in order to take advantage of this possibility, the Stirling engine would have to be powered by heat obtained from biomass combustion.

Other disadvantages include, for example, long start-up times in the case of solid fuel systems and low flexibility in the case of load changes.

\section{Microturbines}

Research and implementation activities on microturbines are currently proceeding in different scientific units and companies. Microturbines are investigated to be applied as expansion machines in many technical applications, such as power generating systems and CHPs [109], unmanned airplanes [110] and hybrid cars [111]. The microturbine implementation was possible thanks to recent progress in different fields of science (especially materials science, thermodynamics, fluid mechanics and computer aided design). Advanced computer aided design (CAD) techniques and numerical flow modeling are widely used to design microturbines, and computer numerical control (CNC) machines are used for manufacturing microturbine parts. By the direction of the working fluid flow through the microturbine, they can be classified into radial and axial machines and by the type of the applied working fluid into gas microturbines and steam microturbines [112]. A characteristic feature of microturbines is their high rotational speed, ranging from several dozen to several hundred thousand revolutions per minute [113]. Therefore, very precise tools must be applied to manufacture microturbines. The microturbine shaft is coupled with the shaft of the generator in a different way than in the case of standard large-power turbines (i.e., small-scale, specially designed high-speed generators are applied and elec- 
tronic systems are used to convert the generated current into a current of frequency and voltage that can be transferred directly to the grid). What is more, due to high rotational speeds of the microturbine shaft and large heat load, magnetic or foil bearings are often applied instead of classically used slide bearings [113]. Compared to volumetric expanders, microturbines are featuring smaller dimensions, a smaller number of moving parts, lower friction losses and higher efficiency [114]. They are also lighter. However, working fluid flow through microturbine and machine cost are much higher.

\subsection{Gas Microturbines}

In recent years, gas microturbines have gained a reputation as a refined technology and are boldly entering a variety of municipal and industrial facilities where reliable, independent electricity and/or heat generation at competitive prices is required. The leaders of this technology are mainly British [115,116], Italian [117] and American [118-120] companies. Currently, their offer includes devices with a power of 50-several hundred $\mathrm{kW}$, and in the future, it is planned to gradually expand this range. Recently, microturbines have had a number of original applications. One of the largest sports and recreation centers in London used a micro-turbine to generate $80 \mathrm{~kW}$ of electricity and $150 \mathrm{~kW}$ of heat for its own facilities and equipment, including a swimming pool, sports hall and other rooms using the Bowman Power TG80CG gas microturbine [115]. This original 80\% efficient power plant has been supplemented with a conventional boiler to cover peak heat loads. The microturbine itself is only a slightly more complex design than a typical low power turbo generator. What distinguishes this device from classic machines of this type is a high-speed, four-pole self-excited generator and dedicated software controlling the operation of the unit. The alternator was made of rare earth metals of extremely high density, which allowed for such a significant reduction of elements that the turbine and generator rotors were placed on one shaft, thus eliminating the troublesome mechanical transmission. This single shaft assembly rotates at over 100,000 rpm producing an output voltage with a frequency in the range of 1000 to $3000 \mathrm{~Hz}$. A special power electronic converter converts them into voltage with a mains frequency of 50 or $60 \mathrm{~Hz}$ and an ideal sinusoidal shape and value. Thus, the unit becomes a reliable power source with a quality that meets the most stringent requirements [121]. Manufacturers produce microturbines in two main types: with and without exhaust gas heat recovery. In microturbines without heat recovery, a compressed mixture of natural gas and air is burnt at constant pressure, and the resulting hot exhaust gas stream expands in the gas turbine, driving the generator. These systems follow a simple thermodynamic cycle and are cheaper and more reliable than microturbines with heat recovery. The latter devices have an exchanger in which part of the heat contained in the turbine exhaust gas stream is transferred to the inlet air. As a result, microturbines with heat recovery are characterized by higher efficiency (fuel savings up to 30-40\%), comparable to diesel-based combined heat and power plants. In some implementations the exhaust/air heat exchanger has been replaced with a hot water boiler. In other applications, the microturbine exhaust stream without heat recovery is routed to the furnace, eliminating traditional gas burners. Currently, microturbines with a capacity of 25-250 kW and an electricity generation efficiency of 30\% are offered in the world. With combined production of electricity and heat, this ratio can reach $80 \%$. Gas microturbines have many advantages and offer a number of advantages, especially when used in small- and micro-power distributed energy. A small number of rotating and moving parts, compact design, small dimensions and weight-facilitate assembly and maintenance. At the same time, very low emission of pollutants and noise level allow their use in virtually every facility. Microturbines can be supplied by different types of fuel, e.g., dairy cattle biogas [122], syngas [123] and biofuels [124].

In [125] authors presented very small model of gas microturbine, featuring only $500 \mathrm{~W}$ of power. The turbine is called the Ultra Micro Gas Turbine (UMGT). The test bench of this turbine is presented in Figure 18. 


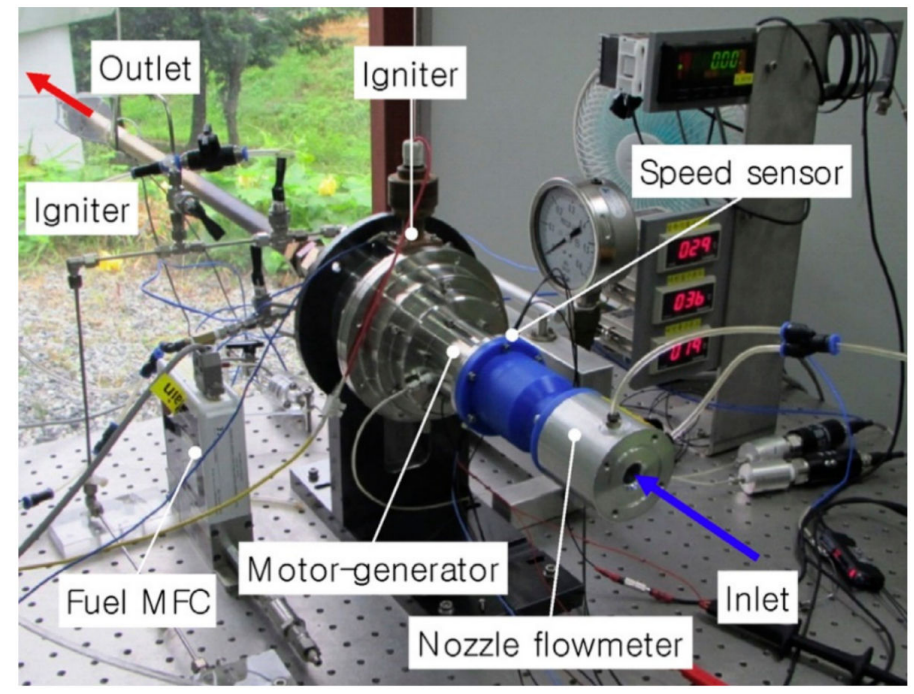

Figure 18. The test bench of the Ultra Micro Gas Turbine (UMGT) power generator [125].

The elements of the tested gas turbine are shown in the Figure 19.

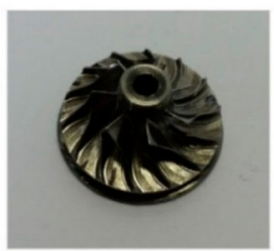

(a)

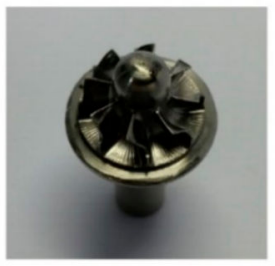

(b)

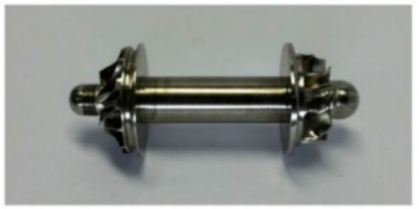

(c)

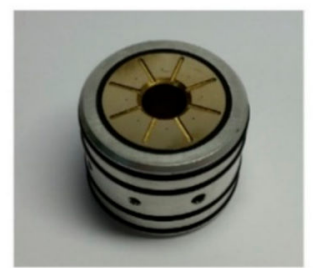

(d)

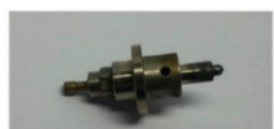

(e)

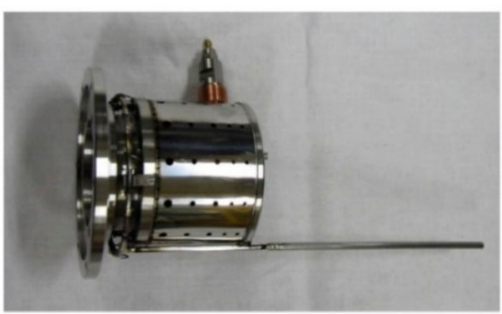

(f)

Figure 19. Elements of the first integrated test rig: (a) compressor, (b) turbine, (c) rotor shaft with compressor and turbine, (d) radial-thrust integral static air bearing, (e) graphite hot-bulb igniter and (f) annular-type combustor with 12 nozzles [125].

Furthermore, the technology of ultra-small gas turbines is presented in [126-130]. Ansaldo Energia [131-133] and Capstone [134] are one of the world's leading manufacturers of micro gas turbines. A view of the Capstone $30 \mathrm{~kW}$ gas turbine is shown in Figure 20. 


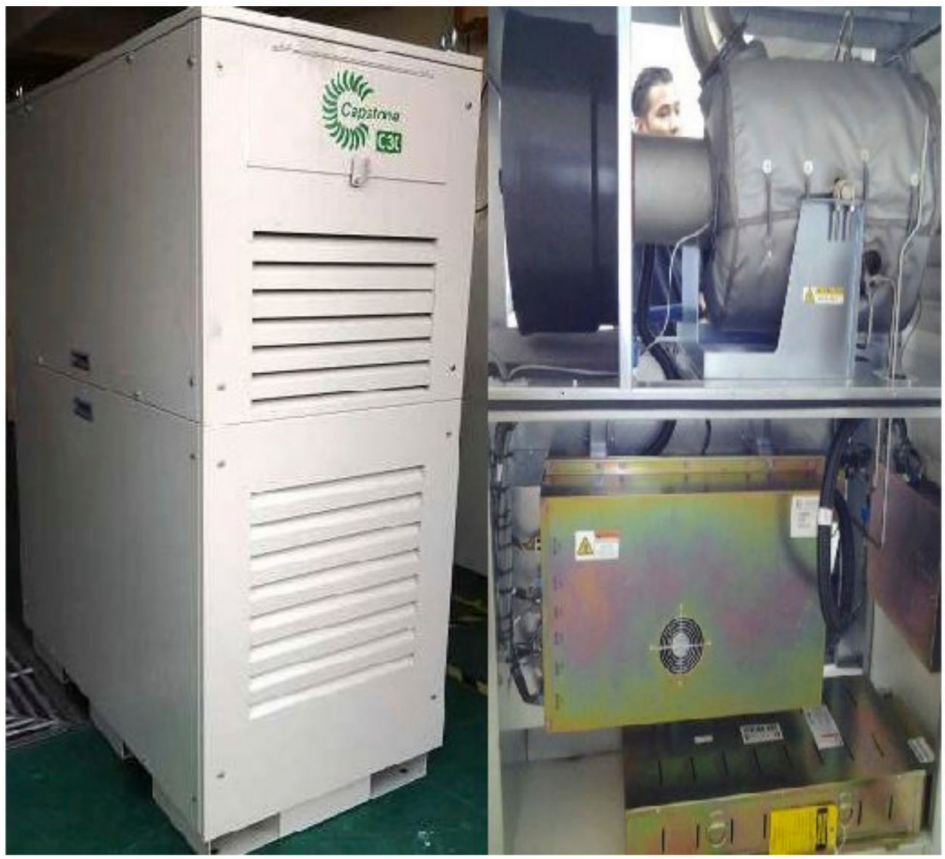

Figure 20. View of the Capstone $30 \mathrm{~kW}$ gas turbine [134].

Ansaldo Energia is a global manufacturer in a distributed generation market with its AE-T100 Gas Microturbine, available in three different versions: natural gas-fired AET100NG, biogas-fired AE-T100B, and fed by heat from external combustion: An example ofEFGT technology is shown in Figure 21. The AE-T100 is producing $100 \mathrm{~kW}_{\mathrm{e}}$ of electrical power and about $200 \mathrm{~kW}_{\text {th }}$ of thermal power. The efficiency of this system is up to $90 \%$. A broad power range is achieved by good modularity of this systems and can spread by adding additional units.

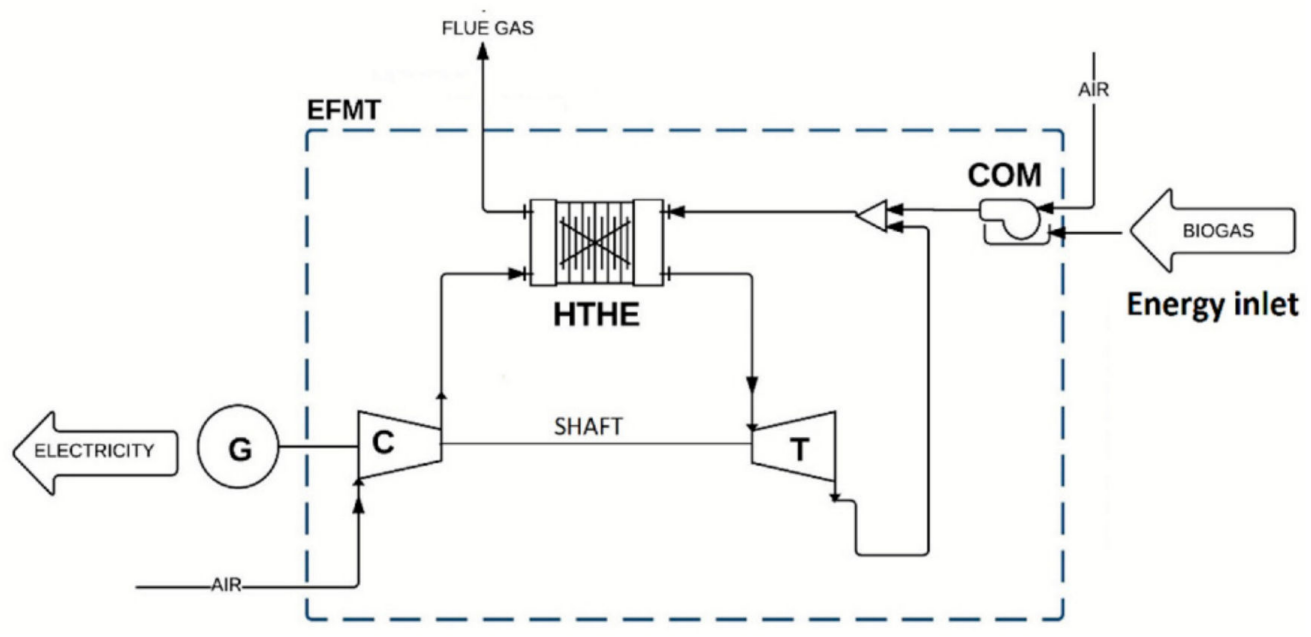

Figure 21. View of the external combustion gas turbine schematic layout [135].

\subsection{Steam Microturbines}

A characteristic feature of microturbines is their high durability and reliability, which results from their relatively simple design, as they have only one rotating element in the form of a shaft assembly with rotors and a generator [136-139]. High rotational speeds are also typical of this type of turbine machine, thanks to which, with small overall dimensions, the microturbines enable a high power output. However, high rotational speeds lead to complications in the design of the clutch connecting the turbine to the generator and bearings [140-144]. 
Many research centers around the world conduct research and development work on the continuous improvement of steam microturbine technology. Works on small steam turbines are carried out by, among others, The Institute of Fluid Flow Machinery of the Polish Academy of Sciences in Gdańsk and the Institute of Turbomachinery of the Łódź University of Technology.

As part of the research tasks proceeded at Institute of Fluid Flow Machinery of the Polish Academy of Sciences, several alternative solutions for devices enabling the conversion of thermal energy into electricity were developed and tested. With the assumed power level and limitations resulting from the target place of operation of domestic conditions, steam microturbines turned out to be the optimal solution. Among the examined expansion devices, the most promising results were obtained for the variant of the four-stage radial microturbine and the single-stage radial microturbine. It was decided to couple the steam microturbine with the ORC system [145-147]. The working fluid in the ORC system is a low-boiling fluid. To drive the microturbine, it is firstly heated in a heat exchanger to the temperature at which the state changes from liquid to gas (evaporation takes place).

The gaseous medium at the appropriate pressure is fed to the microturbine blade system, causing its acceleration and then maintaining a constant rotational speed. The mechanical energy of the shaft rotation is then converted into electricity (by means of a generator) which, after appropriate preparation, can be used e.g., in a household. The lowboiling fluid used to drive the microturbine circulates in a closed system; after condensation, it flows through the pump and then it is reheated [148].

The four-stage microturbine developed at Institute of Fluid Flow Machinery of the Polish Academy of Sciences has two centripetal and two centrifugal stages. The shaft is supported by two radial-thrust gas bearings in which a low-boiling fluid is used as the lubricant. At the nominal rotational speed of approx. 24,000 rpm, the microturbine allows to obtain ca. $2 \mathrm{~kW}$ of electric power [148]. A cross-section through the turbine and the rotor disk is shown in Figure 22.
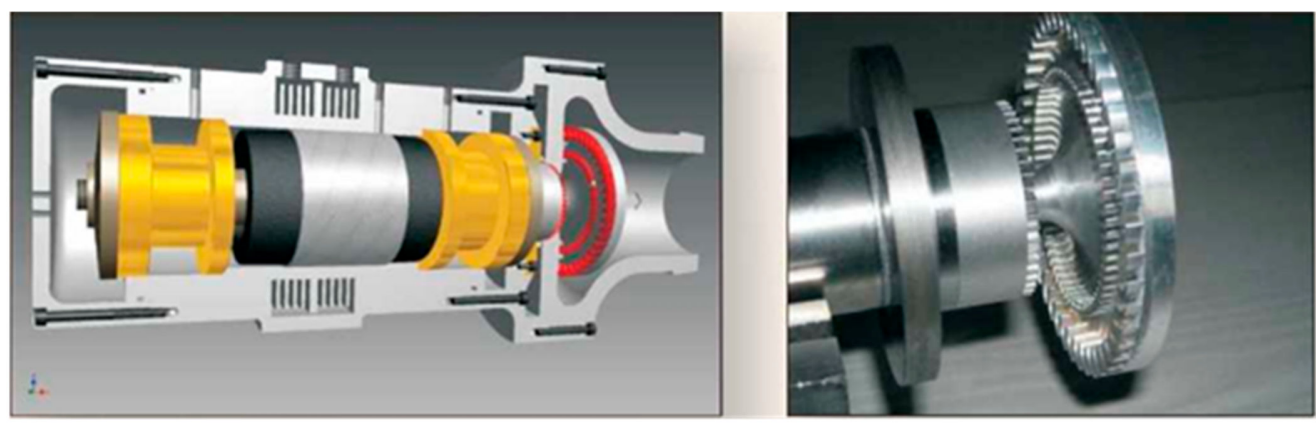

Figure 22. Cross-section and manufactured rotor disc of the four-stage radial microturbine made by Institute of Fluid Flow Machinery [148].

A single-stage microturbine has also been developed at the Institute of Fluid Flow Machinery (see, Figure 23). It is characterized by a centrifugal stage where the flow velocity is more than twice larger than the velocity of sound. It was built on the basis of the experience gained in the implementation of a four-stage microturbine. It uses the previously proven radial-thrust gas bearings, lubricated with a low-boiling fluid. The nominal rotational speed of this micro-turbine is ca. 30,000 rpm, which allows it to generate ca. $2.5 \mathrm{~kW}$ of electricity. 


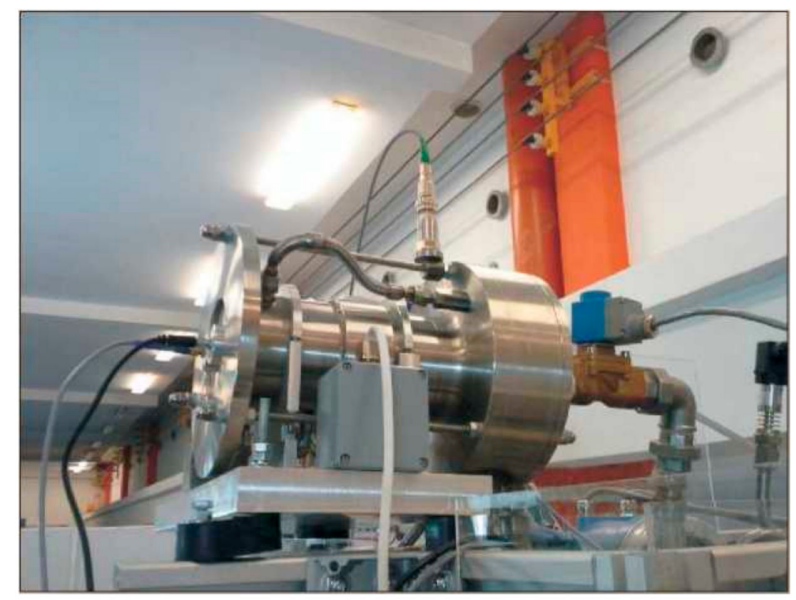

Figure 23. Radial, single-stage steam microturbine installed on the Institute of Fluid Flow Machinery test stand [148].

The developed steam microturbines were tested in the laboratory of Fluid Flow Machinery in conditions corresponding to their operation in the ORC system, using their own control system. Research has shown that prototype microturbine solutions have many advantages. Thanks to the use of high rotational speeds, machines with a compact structure and small dimensions were developed. Unlike other devices that enable the conversion of heat into electricity, steam microturbines are characterized by high durability and reliability because they do not have wear parts and parts that require periodic replacement or repair. Since the same low-boiling fluid is used in the flow system and the bearings, the risk of mixing the working medium, e.g., with oil, has been eliminated. The test results also confirmed the very low vibration level and quiet operation of the developed turbines. The mentioned advantages of microturbines mean that they can be successfully used in domestic ORC micro-cogeneration installations, as well as in other installations requiring a small and reliable device that enables electricity generation [148].

As mentioned earlier, work on small steam turbines is also carried out at the Institute of Turbomachinery of the Łódź University of Technology [136].

The experimental steam turbine with a nominal power of $50 \mathrm{~kW}$ was built on the basis of the Institute of Turbomachinery project. The turbine is powered by a steam generator that uses waste heat from a biogas combustion engine. Firstly, the following live steam parameters were considered: temperature equal to $613 \mathrm{~K}$, pressure equal to $12 \mathrm{bar}$, while the mass flow rate was $0.075 \mathrm{~kg} / \mathrm{s}$. The turbine works in condensing mode. For these parameters, the isentropic drop in enthalpy is as high as $732 \mathrm{~kJ} / \mathrm{kg}$, which excludes a single-stage design, except for the Curtis two-ring (or three-ring) stage, operating in the range of very high Mach numbers. Therefore, after discussion, the live steam temperature was limited. Ultimately, the following turbine design parameters were established [136]:

- live steam: pressure 12 bar, temperature $573 \mathrm{~K}$;

- $\quad$ steam mass flow $0.075 \mathrm{~kg} / \mathrm{s}$;

- $\quad$ pressure in the condenser 0.25 bar;

- rotational speed $6276 \mathrm{rpm}$.

The rotational speed was imposed due to the unavailability of a suitable gear.

A small backpressure turbine was also designed at Institute of Turbomachinery of the Łódź University of Technology. It generates $165 \mathrm{~kW}$ of power. The turbine was designed to cooperate with the existing technological installation; therefore, its operating parameters were strictly defined and were not subject to any discussion. These parameters were established as follows:

- $\quad$ live steam: pressure $5.8 \mathrm{bar}$, temperature $553 \mathrm{~K}\left(280^{\circ} \mathrm{C}\right)$;

- steam mass flow $2 \mathrm{~kg} / \mathrm{s}$;

- 3.5 bar back pressure. 
In this case, the isentropic enthalpy drop is only $119.7 \mathrm{~kJ} / \mathrm{kg}$, which greatly facilitates the adoption of the advantageous design solution. After preliminary calculations, it was assumed that the turbine would be implemented as a single action stage, powered on the entire circuit.

Experimental research on the application of a microturbine (featuring a maximum power of $1.9 \mathrm{~kW}$ ) in domestic ORC CHP systems using ethanol as a working fluid was also proceeded at the Gdańsk University of Technology. The results of these experiments were reported in [149-152]. The experimental tests were proceeded for varied thermodynamic parameters of the working fluid at the inlet and at the outlet of the microturbine. The pressure at the inlet to the machine was varied between 0.36 and $0.6 \mathrm{MPa}$, while the working fluid flow was varied between 15 and $20 \mathrm{~g} / \mathrm{s}$. The maximum temperature of the working medium at the inlet to the machine was equal to $143{ }^{\circ} \mathrm{C}$. For these experimental conditions, the obtained electric power of the ORC system was ranging between 0.66 and $0.76 \mathrm{~kW}$, electrical efficiency was ranging between 6.40 and $6.65 \%$ and the total efficiency of the ORC CHP system was ranging between 22.53 and $23.54 \%$ [150].

There are also suppliers on the world market that offer microturbine technology. One of them is Spirax Sarco. This technology is described in more detail in [153]. An example of a Spirax Sarco steam microturbine in a container version is presented in Figure 24.

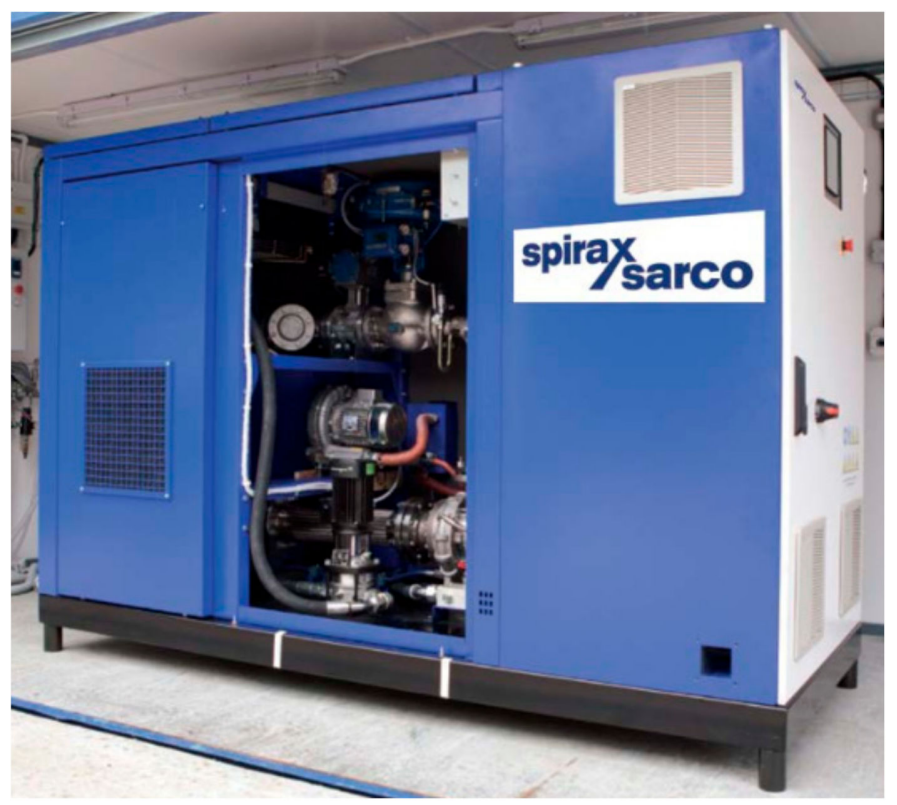

Figure 24. View of the Spirax Sarco steam microturbine [153].

Other companies that have in their portfolio steam microturbines are e.g., Siemens Dressel-Rand and General Electric.

\section{Volumetric Expanders (Vane, Lobe, Screw, Piston, Wankel, Gerotor)}

Volumetric expanders can be applied in small CHP steam and ORC systems as an alternative to the earlier described microturbines. The principle of operation of volumetric expander differs from that of turbine. In the case of volumetric machine, the working fluid expansion proceeds in a working chamber which volume is limited by the cylinder and the displacer. The operation of volumetric expander is cyclical and working chamber volume changes during machine operation. For this reason, gas expansion processes are proceeding periodically. Compared to microturbines, volumetric expanders are featuring simpler design and lower investment costs. What is more, they are also featuring lower rotational speeds, higher pressure drops that can be obtained in one stage, lower mass flows of the working fluid and the possibility of wet-gas expansion. In selected cases, it is possible to design and implement oil-free volumetric expanders. 


\subsection{Vane Expanders}

The design of the vane expanders is very simple, which translates into low production costs. This machine has a favorable ratio of the output power to its external dimensions. The use of special construction materials makes it possible to eliminate the need for lubrication. Compared to other types of volumetric machines and microturbines, vane expanders are characterized by a lower fluid flow rate and a lower pressure ratio. Moreover, the vane expanders can be hermetically sealed, which is one of the key issues in the cooperation of this type of expander with the ORC system [154]. This type of machine is insensitive to the negative impact of the expansion of the gas-liquid mixture, which is a great advantage when ORC systems are supplied by heat sources with variable thermal parameters.

Vane compressors and expanders are used in many industries, including mining, refrigeration and pneumatic systems [155]. Vane expanders have an output power from several dozen watts to about a dozen kilowatts. The maximum gas pressure at the inlet to the vane expander is approximately $30 \mathrm{bar}$. These machines are characterized by rotational speeds from several hundred to 10,000 rpm. Research on vane expanders is carried out, among others at the Wrocław University of Science and Technology. The implemented experimental CHP ORC test stand uses multi-vane expander featuring the maximum power output of $300 \mathrm{~W}$ and gas central heating boiler featuring a thermal power of $24 \mathrm{~kW}$ serves as a heat source. The view of the test stand and expander is shown in Figure 25.
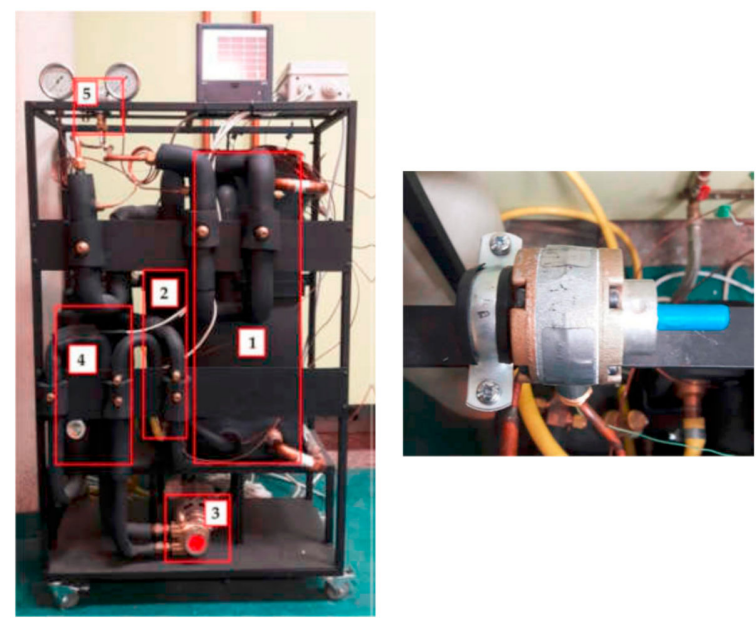

Figure 25. General view of the test stand and expander. Left: 1 -plate evaporator, 2 -plate condenser, 3-pump, 4-tank 5-multi-vane expander; on the right-general view of the expander [154].

As already mentioned, the design of the vane expanders is simple. Figure 26 shows the components of a vane expander.

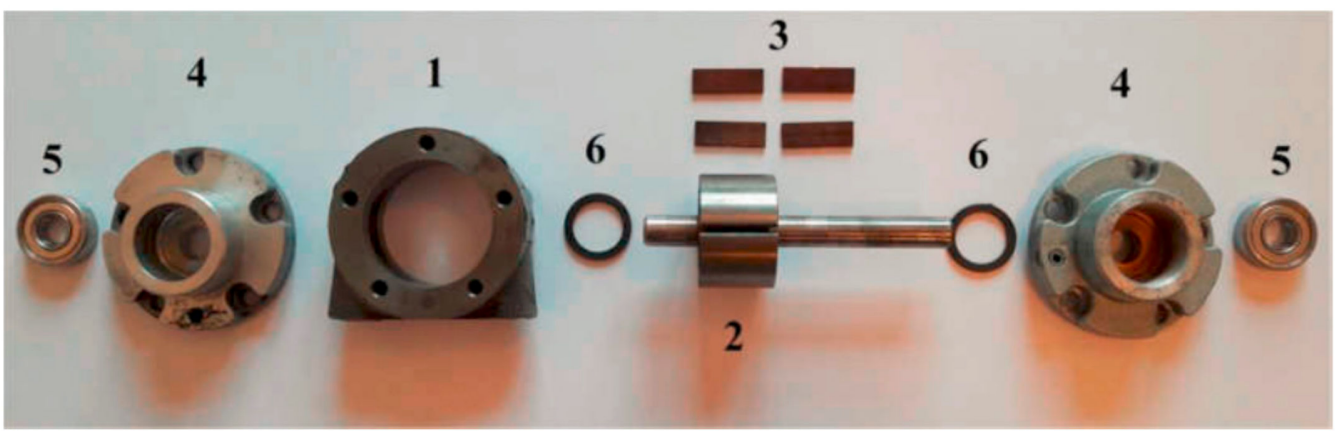

Figure 26. The individual elements of a vane expander: 1-body, 2-rotor, 3-blades, 4-housing, 5-bearings, 6-rings [154]. 
Based on the available literature [156-159], it can be stated that vane expanders are devices on a rather smaller scale. The maximum currently available units, when coupled with the ORC system, reach the power of $7.5 \mathrm{~kW}$.

\subsection{Lobe Expanders}

Rotary lobe expanders are devices that are not currently in mass production. Work on them is still ongoing. Their design is derived from pneumatic motors [160]. The design of such an engine is shown in Figure 27.

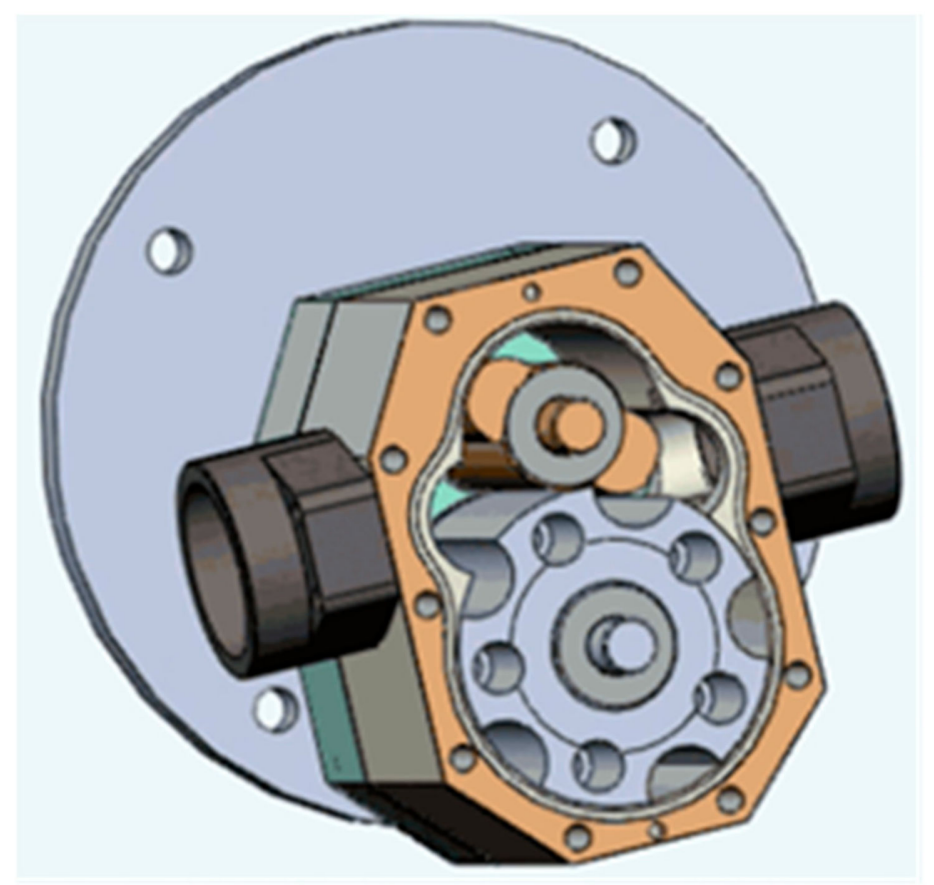

Figure 27. View on the Armak pneumatic motor [160].

Rotary lobe expanders can be used as heat engines in energy systems powered by different heat sources (e.g., biomass boilers, waste heat recovery boilers, parabolic solar collectors, etc.). The experimental units work in small steam plants. The company that is currently conducting research on this type of expanders is the Polish company Termo2Power. The works are carried out under the research project "PBSE Power Sector Research Program" carried out under the contract with the National Center for Research and Development. Part of the substantive work is carried out by a team from the Faculty of Power and Aeronautical Engineering of the Warsaw University of Technology. The company also conducts tests of its own designs, including multi-stage expanders. These expanders can work with medium pressure from 8 to 40 bar. The inlet medium temperature should not exceed $350{ }^{\circ} \mathrm{C}$ due to sealing problems. In this type of devices, no labyrinth seals are used, but classic seals that must withstand high temperatures. The capacities of these devices range from single kilowatts up to ca. $150 \mathrm{~kW}$ for a single stage expander. It is also practiced to combine expanders into multi-stage systems. Then a system with a power of several hundred kilowatts can be configured. Figure 28 shows the Termo2Power rotary lobe expander and Figure 29 shows this expander connected to the generator and with flexible connectors for supplying and discharging steam. 

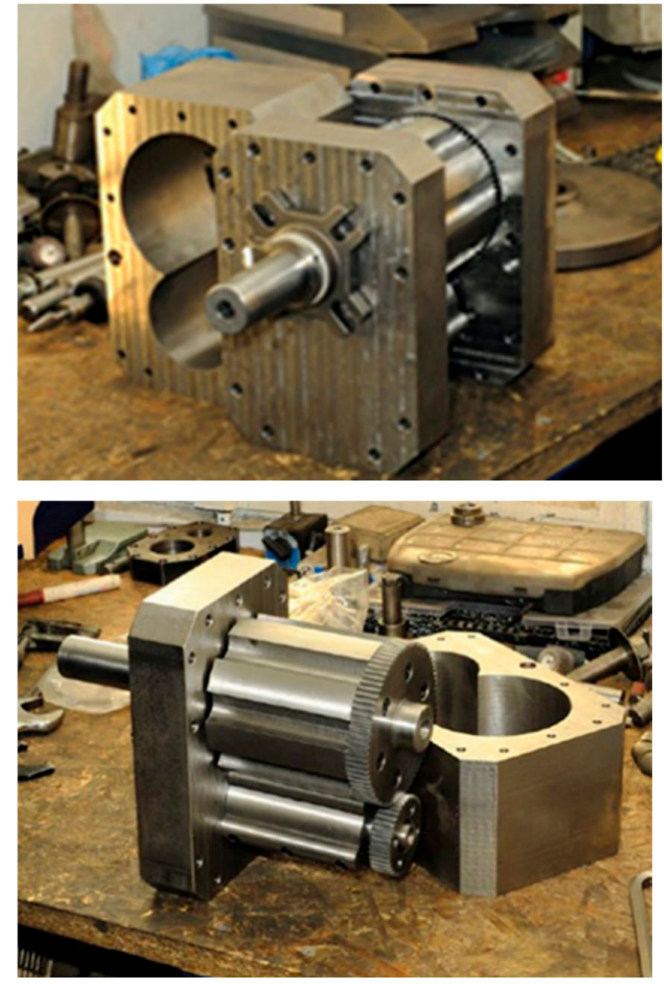

Figure 28. View of the Termo2Power rotary lobe expander [161].

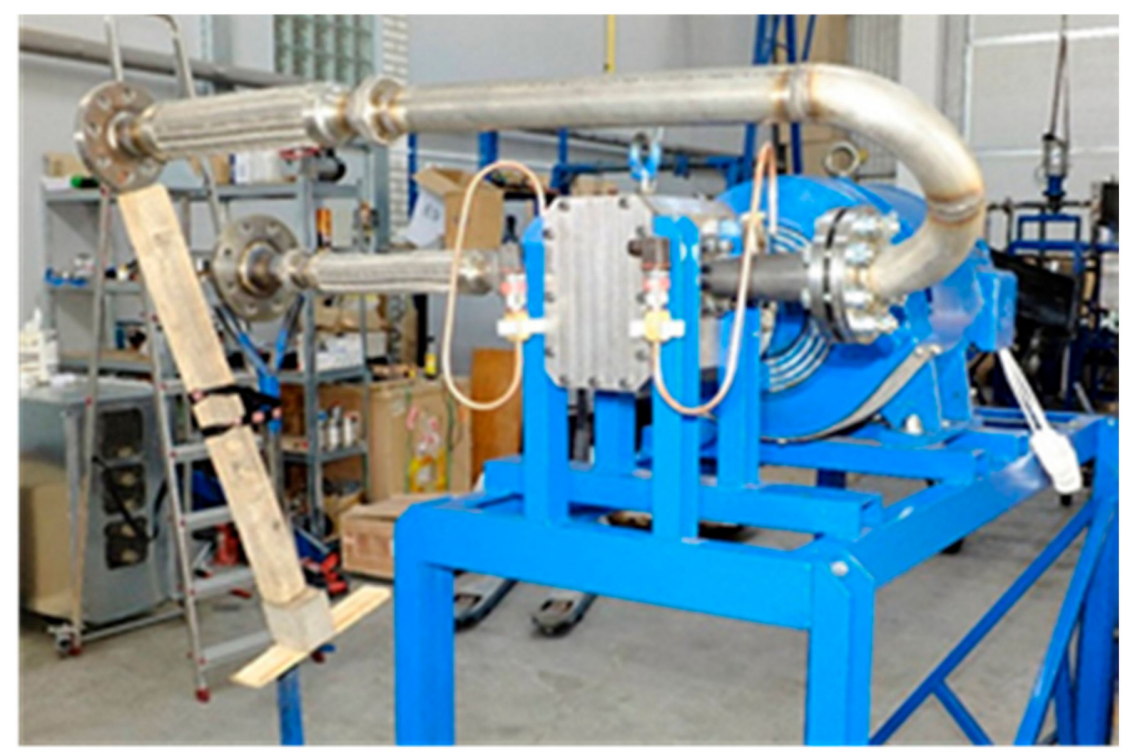

Figure 29. View of Termo2Power rotary lobe expander connected to the generator and pipings [161].

The figure below (Figure 30) shows a system with two rotary lobe expanders and interstage superheating. The boiler is visible on the left side. The expanders are coupled to the generators (blue). The power take-off (electric heaters) is visible under the expanders system. 


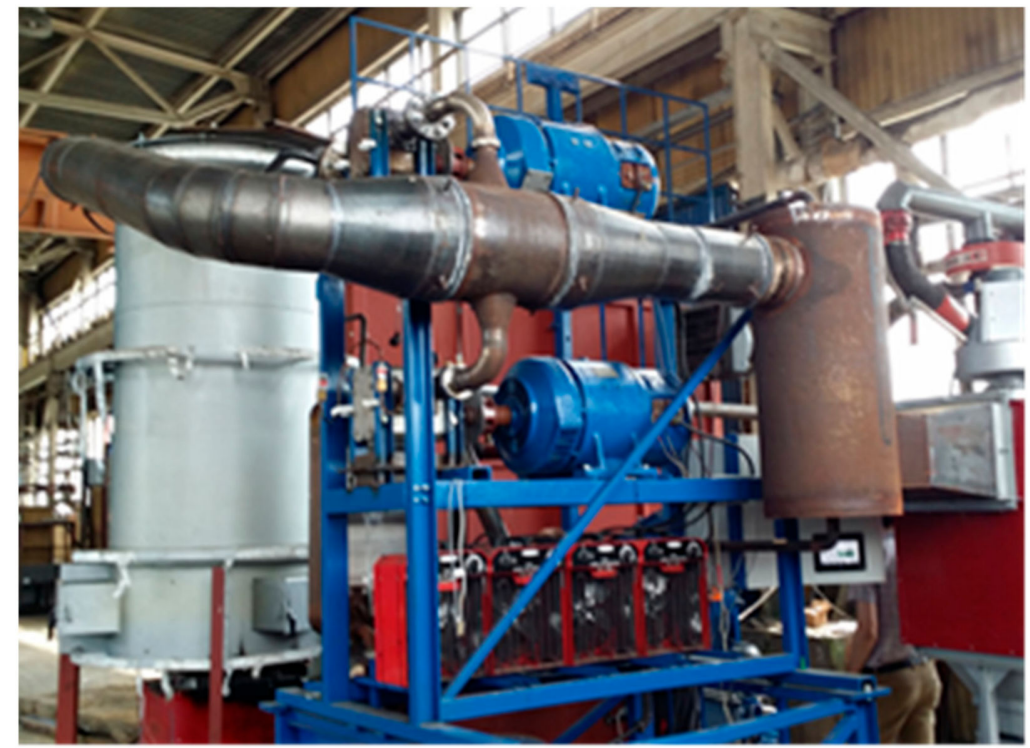

Figure 30. View of a two-stage steam rotary lobe expander with inter-stage superheating [161].

In addition to the aforementioned Termo2Power company, Katrix from Australia is another manufacturer that produces lobe expanders. The expander of this company is of a slightly different design from the Termo2Power expander. A description of this expander and analysis of its operation can be found in [162,163]. Its view and principle of operation are shown in the Figure 31.

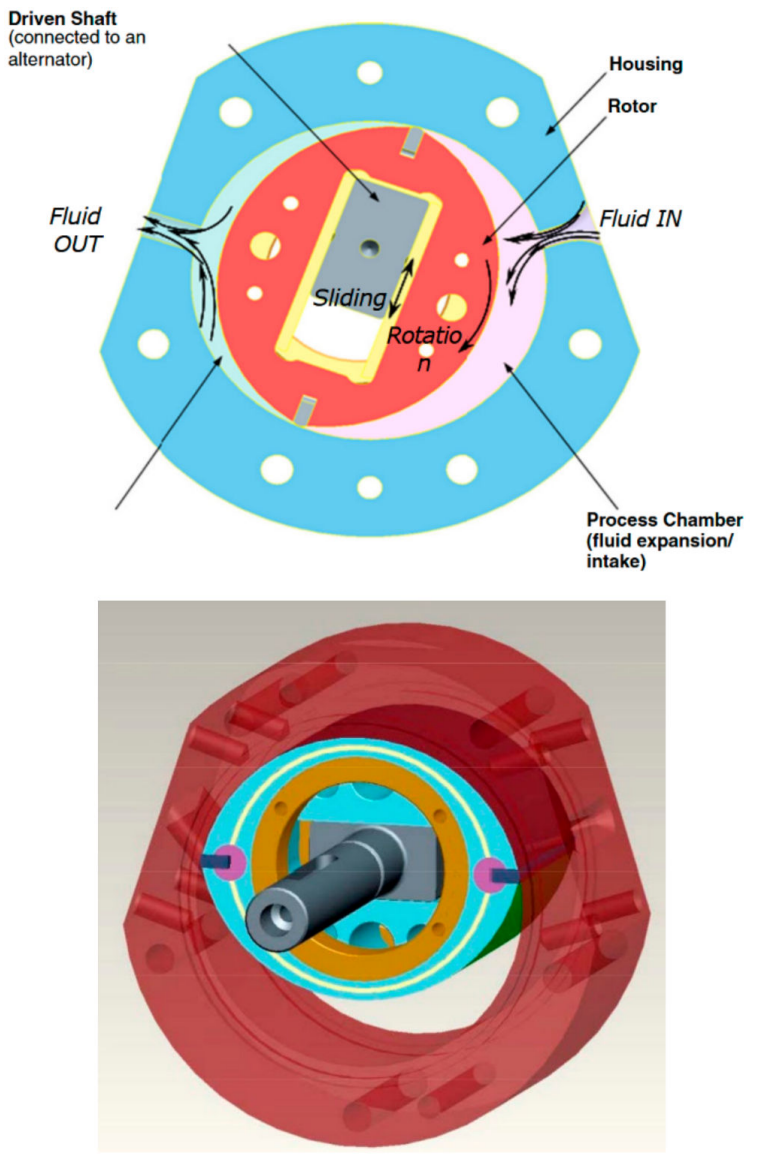

Figure 31. View of a Katrix expander construction [162,163]. 
Expander made by the Katrix company was under investigation as a part of the electricity generation system. The system based on solar collector to produce hot working fluid can be seen in the Figure 32. The expander connected to the pipings and generator is presented in Figure 33.

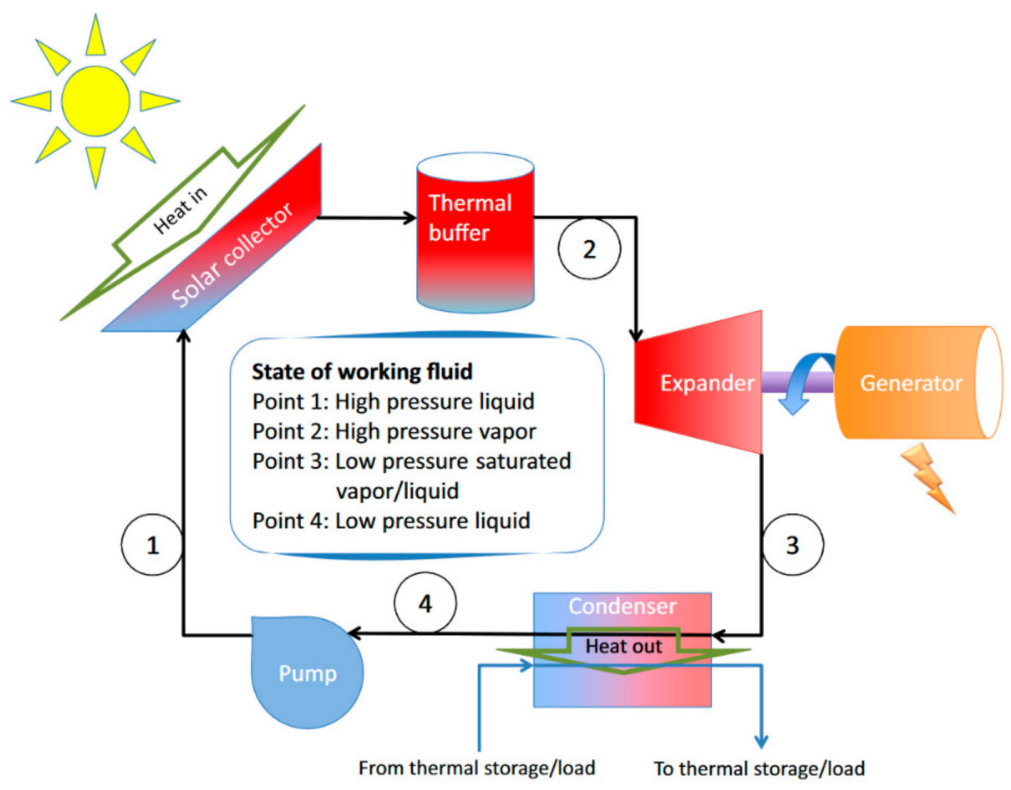

Figure 32. A solar Rankine microcogeneration system with Katrix expander [162,163].

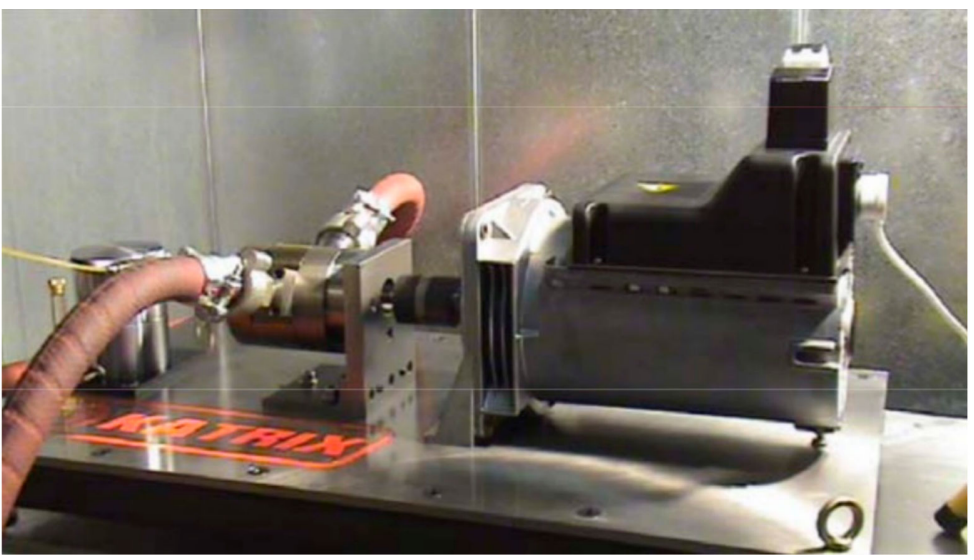

Figure 33. View of a Katrix expander connected to the source of working fluid and generator [162,163].

Roots expanders are the other lobe-type expanders that are currently investigated to be applied in ORCs. Roots expander is a two-shaft, rotary, positive displacement machine, featuring the transverse flow of the working fluid [164-167]. The results of experimental tests of a Roots expander operating in the ORC system are presented in [166]. The tests were carried out using a mixture of R245fa and oil to provide the expander lubrication. The working fluid pressure at the inlet to the machine was varied in the range between 3 and 10.8 bar. The working fluid pressure at the outlet of the machine was ranging between 1.35 and 2.25 bar. The rotational speed of the expander was varying between 1500 and $11,000 \mathrm{rpm}$. The highest isentropic efficiency of the expander (ca. 50\%) was achieved for the rotational speed of ca. $4500 \mathrm{rpm}$ and for small expansion ratio of ca. 1.5. However, for these operating parameters low power output was achieved (ca. $100 \mathrm{~W}$ ). In order to increase the power output to ca. $3 \mathrm{~kW}$ it was necessary to increase the expansion ratio to ca. 3.5. 


\subsection{Screw Expanders}

The screw expander is a displacement type device. It consists of an interlocking pair of spiral rotors placed in a housing, which together form the working chamber. In addition to the pair of screw rotor and cylinder, the structure consists of bearings, synchronous gears, a seal assembly, etc.

The expander has the opposite operating principle to the screw compressor, which has a similar basic structure. The production process and control system are much more complex for an expander than for a screw compressor.

A cross-sectional view of the screw expander is shown in Figure 34.

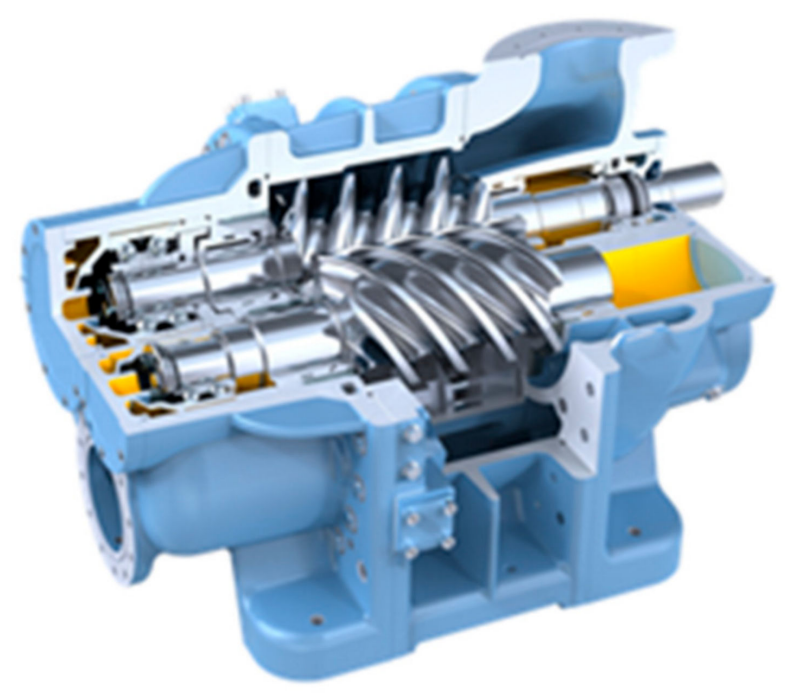

Figure 34. View of the screw expander made by Green Secure Power Systems [164].

Screw expanders can work with superheated steam and wet steam. Currently available units are powered by a working medium with a pressure of 3 to 25 bar. The power range of screw expanders ranges from a few kilowatts to $630 \mathrm{~kW}$.

The world leader in the production of systems with a screw expander is the British company Heliex Power. One of the Heliex devices was installed in Poland in KędzierzynKoźle at Grupa Azoty in 2016. The installation was performed together with the Polish partner of Heliex-the Zamkon company. The device installed in Poland is $160 \mathrm{~kW}$. Figure 35 shows a container system with a screw expander installed at Zakłady Azotowe Kędzierzyn.

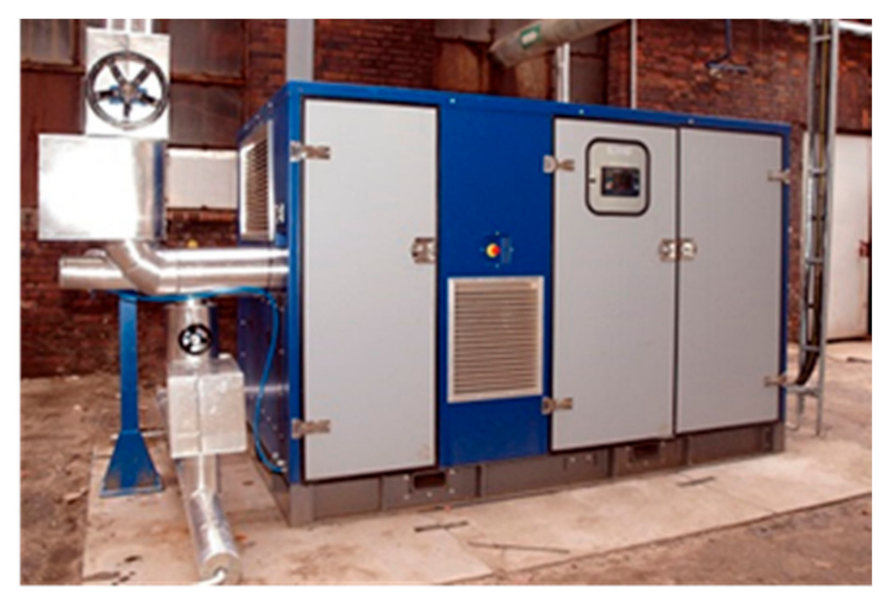

Figure 35. View of the screw expander made by Heliex Power installed at Zakłady Azotowe Kędzierzyn [164]. 
The layout of the example system based on screw is presented in Figure 36.

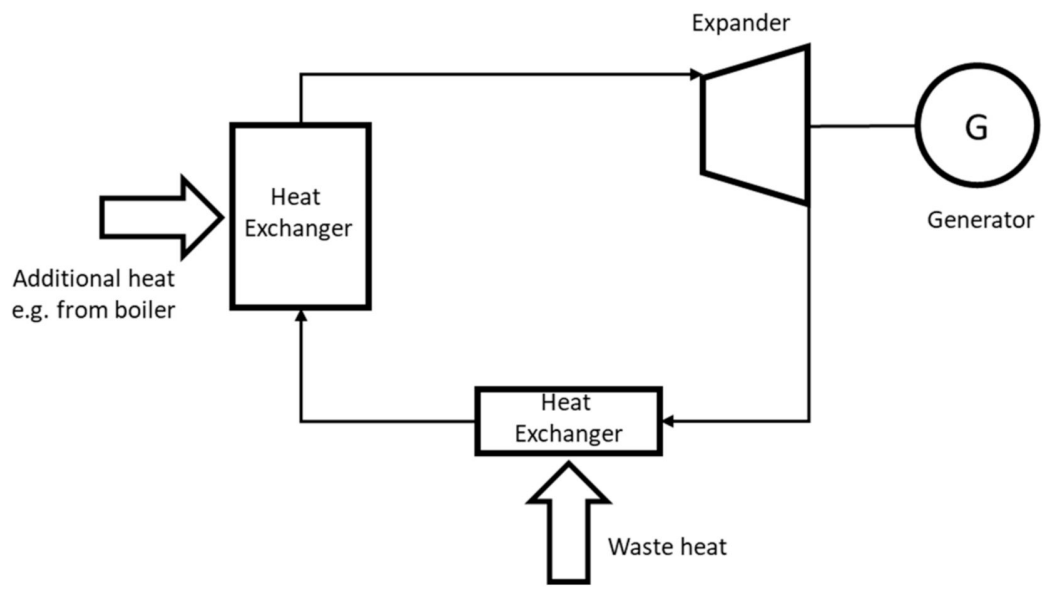

Figure 36. View of the system with screw expander.

The American company ELECTRA THERM [167] developed ORC system using screw expander that can be fed by different heat sources (i.e., geothermal water, biomass combustion products, waste steam or hot water from industrial processes. The minimum temperature of these sources should be $90^{\circ} \mathrm{C}$. The system can be also supplied with waste gases featuring different temperature $\left(205-540^{\circ} \mathrm{C}\right)$. The power output of this system ranges between 50 and $500 \mathrm{~kW}$, depending on the thermal power of the heat source.

Screw expander is also applied in the ORC system developed by the German company KÖHLER-ZIEGLER [167]. This system can utilize waste heat carriers featuring a minimum temperature of $90^{\circ} \mathrm{C}$. The power output of this system ranges from 50 to $200 \mathrm{~kW}$, depending on the heat source thermal parameters. The ORC systems with screw expanders are also manufactured by the Swedish company OPCON [167]. These ORC systems are featuring a modular design and a power output of 350,500 and $800 \mathrm{~kW}$. These systems can utilize waste heat sources featuring a temperature of $55-120^{\circ} \mathrm{C}$. Substances featuring a temperature of $0-30^{\circ} \mathrm{C}$ can be used as the condenser coolant. The efficiency of these systems is ranging between 5 and $10 \%$.

The other types of screw expanders that are applied in ORCs are single-screw expanders. The results of research on these expanders are presented in [168-177]. Single-screw expanders consist of three movable rotors, one of which is the main rotor, located centrally. The main rotor has helical teeth cut around the circumference. The other two rotors are having outer teeth of a rectangular cross-section. The teeth of the cooperating rotors mesh with the teeth of the main helical rotor. In this way, working chambers are formed on both sides of the central rotor.

Single-screw expanders can operate with different working fluids, including natural gas, superheated and saturated steam and liquid-gas mixtures. The power output of these expanders is in the range of 1-100 kW. Single-screw expanders feature a simple design, good performance at part load, high volumetric efficiency and low leakage rate. They are operating quietly and do not generate vibrations. Experimental research on application of single-screw expanders in ORC systems were proceeded in different research centers. In [173] studies on the ORC system utilizing a single-screw expander and using Solkatherm SES36 as a working fluid were described. The working fluid temperature at the inlet to the expander was varied in the range of $119.3-125^{\circ} \mathrm{C}$, the inlet pressure was varied in the range 4.5-10.2 bar, the expansion ratio in the range 3.12-10.97 and the expander rotational speed in the range 2000-3000 rpm. For these experimental conditions, the internal efficiency of the expander was ranging between $51 \%$ and $64.78 \%$ and expander rotational speed was ranging between $2000 \mathrm{rpm}$ and $3000 \mathrm{rpm}$. The maximum power output of the expander of $7.8 \mathrm{~kW}$ and the efficiency of the ORC system of $9.8 \%$ was achieved during experiments. 
Preliminary tests on single-screw expander prototype, which was designed for application in ORC systems, were also carried out with the use of air [171,176]. The total expander efficiency of $55 \%$, the maximum torque of $100 \mathrm{Nm}$ and the power output of $22 \mathrm{~kW}$ were achieved experimentally [176]. In [171] the results of research on a singlescrew expander, which was supplied with compressed air (pre-heated to temperature of $80^{\circ} \mathrm{C}$ ) were reported. The experimental results showed that depending on the expander rotational speed (which was varied between 500 and $3500 \mathrm{rpm}$ ) the expander power output varied in the range of 1-5 kW. Expansion ratio was kept in the range 5-6.75, gas temperature drop was observed in the range $32.5-62.5^{\circ} \mathrm{C}$ and the expander efficiency was varying in the range $10-60 \%$. Single-screw expanders were also tested using R123. The results of these experiments are reported in [175]. The expander power output of $8.35 \mathrm{~kW}$, internal efficiency of $56 \%$ and the maximum efficiency of the ORC system of $7.98 \%$ were achieved. In [168] the results of experiments on a single-screw expander using R245fa as a working fluid were presented. In [173] the results of experimental studies on a single-screw expander applied in an ORC system utilizing SES36 as a working fluid were presented. The experimental tests were proceeded for varied thermodynamic parameters of the gas at the inlet to the expander. The temperature of gas at the inlet to the expander was varied in the range of $100-125^{\circ} \mathrm{C}$, the inlet pressure was varied in the range of 3-7.5 bar and the outlet pressure was kept in the range of $0.6-0.8$ bar. The expander rotational speed was $3000 \mathrm{rpm}$. For these experimental conditions, the achieved expander output power was ranging between 1.5 and $6 \mathrm{~kW}$ and the achieved internal efficiency was ranging between 51 and $66 \%$. In [170] the results of experimental studies which were proceeded on six prototypes of single-screw expanders featuring a power output between 5 and $172 \mathrm{~kW}$ were reported. The applied working fluid was R123. For varied experimental conditions the expanders efficiency varied between $52 \%$ and $73 \%$ and the efficiency of the ORC system reached $9.3 \%$.

\subsection{Piston Expanders}

In a piston expander, the working chamber is formed by the inner surface of the cylinder and the surface of the moving piston. The piston reciprocates in the cylinder between top and bottom dead position and is driven by the crank mechanism. Studies on the possible application of piston expanders in micro steam and ORC systems have proceeded for many years.

The results of research on application of a small piston expander in the ORC system utilizing R134a as a working fluid are reported in [178-180]. The tested expander was manufactured by StarEngine company. The expander features a total displacement of $230 \mathrm{~cm}^{3}$ and is hermetically coupled in one casing with a generator. The general view of this expander is presented in Figure 37.
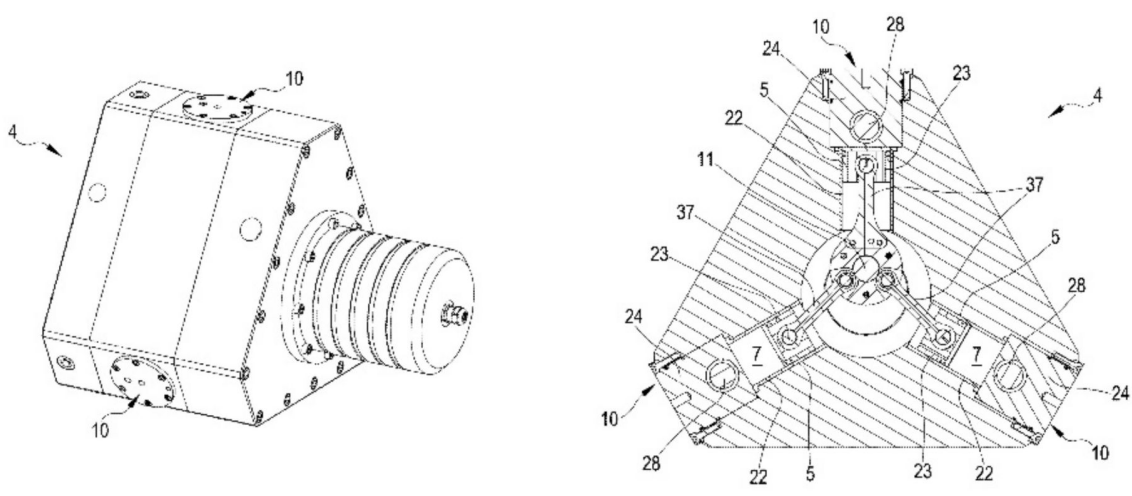

Figure 37. StarEngine piston expander [178-180].

The experimental research on this expander was carried out for varied heat source and heat sink temperature. Heat source temperature was varied in the range $65-85^{\circ} \mathrm{C}$ 
and the temperature of the heat sink was varied in the range $28-27^{\circ} \mathrm{C}$. The mass flow rate of the working fluid was varied between 0.05 and $0.14 \mathrm{~kg} / \mathrm{s}$, pressure in the evaporator was varied between 11 and 19 bar and pressure in the condenser was varied between 6 and 7 bar. For these experimental parameters, an electric power output of 250-1200 W was achieved while expander rotational speed was ranging between 320 and $1100 \mathrm{rpm}$. The total efficiency of the expander-generator unit was varying between 38 and $42 \%$. The achieved gross efficiency of ORC system was $4.5 \%$ while the achieved net efficiency was $2.2 \%$.

In [181] the results of experimental tests carried out on a prototype oil-free piston expander designed for application in steam distributed generation systems are reported. The electric power output of the tested expander ranges between 740 and $2400 \mathrm{~W}$ depending on the parameters of the working medium. During the experiments the thermal parameters of the working fluid at the inlet to the expander were varied in the range $260-340{ }^{\circ} \mathrm{C}$ and 20-34 bar. The experimentally achieved internal efficiency of the expander was varying between 19 and $40 \%$. This type of steam expander is also promising for application in ORC systems [181]. In [182,183] the results of research on a piston expander featuring a power of $3 \mathrm{~kW}$ and applied in the ORC system are presented. The expander is a modified reciprocating compressor with a specially designed control valve.

In [184] the authors presented the results of modeling of the operation of a piston expander designed for application in waste heat recovery system from the passenger car exhaust gases. Modeling results showed the possibility of obtaining an expander power output of $7 \mathrm{~kW}$ and an isentropic efficiency between 55 and $70 \%$.

In [185] the results of experimental research on a swash-plate piston expander featuring a displacement of $195 \mathrm{~cm}^{3}$, which was implemented in the ORC system using blowing agent R245fa as a working medium are presented. This type of expander uses a swash-plate to transmit torque from the pistons to the shaft. The cross-section of swash-plate expander is presented in Figure 38.

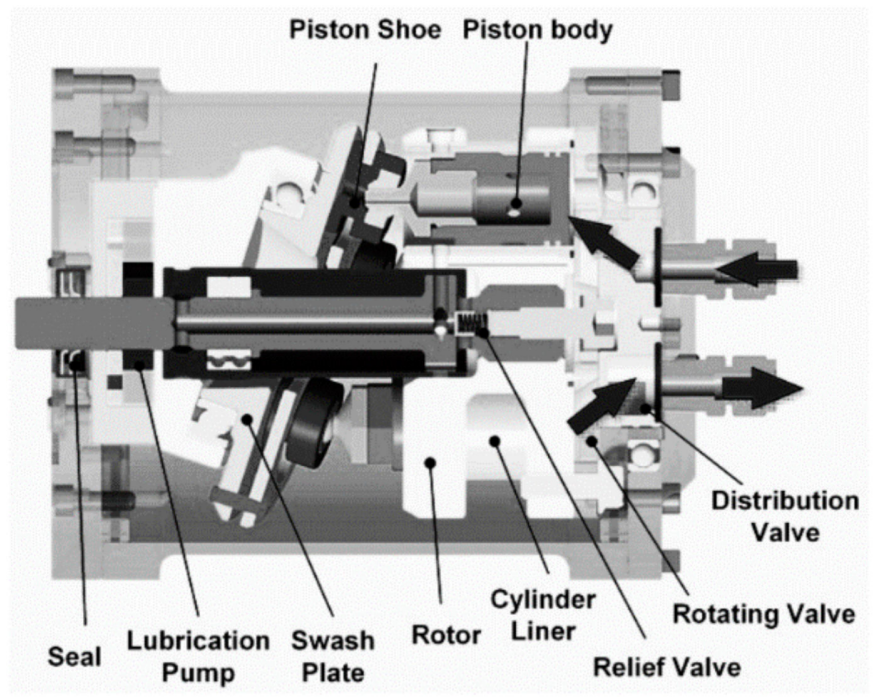

Figure 38. Cross-section of a swash-plate piston expander [185].

The tests of the expander were proceeded for gas inlet pressures ranging between 18 and 30 bar and the rotational speed of the expander ranging between 1000 and $4000 \mathrm{rpm}$. For these experimental conditions working fluid pressure at the outlet of the expander was ranging between 2.9 and 4.02 bar. The inlet pressure was regulated by changing the mass flow rate of the working fluid by means of a pump. Depending on the operational conditions working fluid was superheated in the range of 4-17 K and working fluid mass flow rate was varied between 29 and $105 \mathrm{~g} / \mathrm{s}$. The obtained mechanical power of the expander was ranging between 0.3 and $2 \mathrm{~kW}$ while the maximum achieved internal efficiency of the expander was $53 \%$. The mechanical efficiency of the expander was ranging 
between 50 and $85 \%$. The results of research on swash-plate expanders were also reported in $[186,187]$.

In addition to the piston expanders discussed above, linear piston expanders are also investigated to be applied in ORC systems. Research results on this type of expansion machines were reported in $[188,189]$. In a linear piston expander, the linear arrangement of the cylinders is applied. This design is similar to the boxer arrangement of cylinders, but does not use a crankshaft. A linear generator is placed between the cylinders. The piston rods of the opposing pistons are connected to each other by a piston rod of a linear generator. The kinetic energy of the reciprocating movement of the piston rod is converted into electricity in a linear generator. The cross-section of linear piston expander is presented in Figure 39. In [190] the test results and design guidelines for a linear piston expander that can be applied in a micro-power ORC systems used for waste heat recovery from automotive engines were presented.

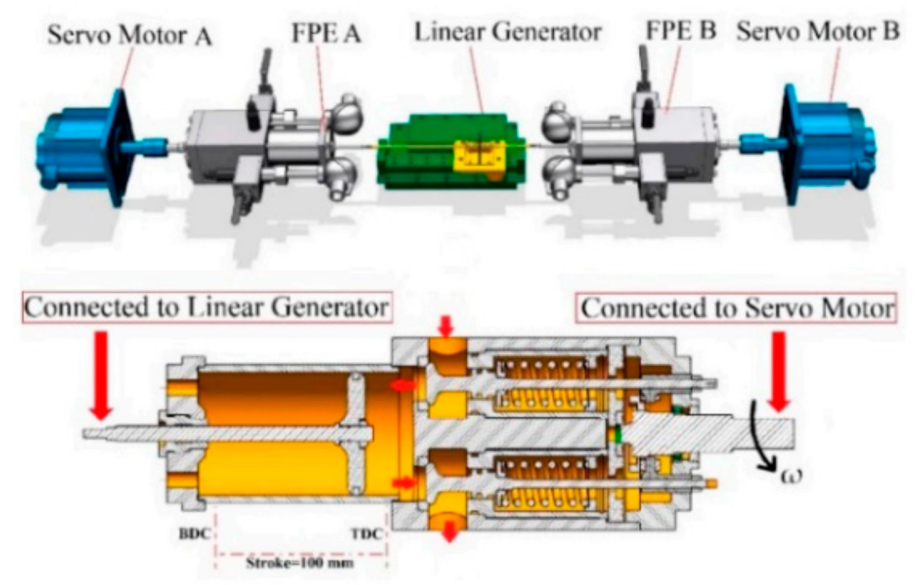

Figure 39. Cross-section of a linear piston expander [190].

It has been reported [190] that incomplete expansion (pressure of the working medium in the cylinder after expansion is higher than the pressure of the working medium in the outlet channel from the expander), heat transfer, flow losses during filling and evacuation of the working fluid from cylinder, friction and leakages are the main phenomena limiting the efficiency of linear piston expanders. It has also been shown that appropriate valve control has a significant impact on the linear piston expander operation and pressure losses occurring on the valves. The results of the tests carried out on the prototype of the linear piston expander showed that for gas inlet pressures ranging between 0.13 and $0.21 \mathrm{MPa}$, the internal efficiency of the expander varies in the range $66.2-93 \%$ and decreases with increasing inlet pressure. The highest power output of $22.7 \mathrm{~W}$ was achieved for the gas inlet pressure of $0.2 \mathrm{MPa}$ and internal efficiency of $66.2 \%$.

Compared to the other types of volumetric expanders (such as e.g., lobe, screw and Wankel expanders), piston expanders are characterized by a much simpler design; however, they require lubrication, valve timing, and generate vibrations during operation.

\subsection{Wankel Expanders}

Wankel expanders are positive displacement machines featuring rotational displacement movement. These machines are currently experimentally tested to be applied in small steam and ORC systems [191-196]. The principle of operation of the Wankel expander is similar to that of the Wankel engine, but unlike in the engine, the combustion of fueloxidant mixture is not proceeded in the expander. A Wankel expander use a triangular rotor which moves in an oval cross-section cylinder and the side edges of which are curveshaped. The cylinder is closed on both sides with covers in which inlet and outlet ports are placed. The crank shaft, which drives the rotor, is mounted on bearings embedded 
in the side covers. The shaft is coupled to the rotor by means of a gear that synchronizes their mutual movement. The gear consists of a fixed rack, which is embedded in the side cover of the machine, and a ring rack assembled inside the rotor. Vane seals are placed in the tips of the triangular rotor. Seals limit gas leakage between the working chambers and separate the working chambers from each other. Seals are also placed on the rotor faces to limit gas leakage between the piston and side covers. The cross-section through the Wankel expander, with a description of the most important components of this expander, is presented in Figure 40a. The machine has two inlet and two outlet ports, thanks to which the gas can be expanded in two working chambers at the same time. The working fluid is supplied to the machine through two inlet ports (see Figure 40a) and the working fluid pressure exerted on the rotor causes its motion. Dosing of the working fluid to the working chambers is proceeded via the inlet and outlet valves which opening is controlled by timing belt driven by the rotating crank shaft (see, Figure 40b).

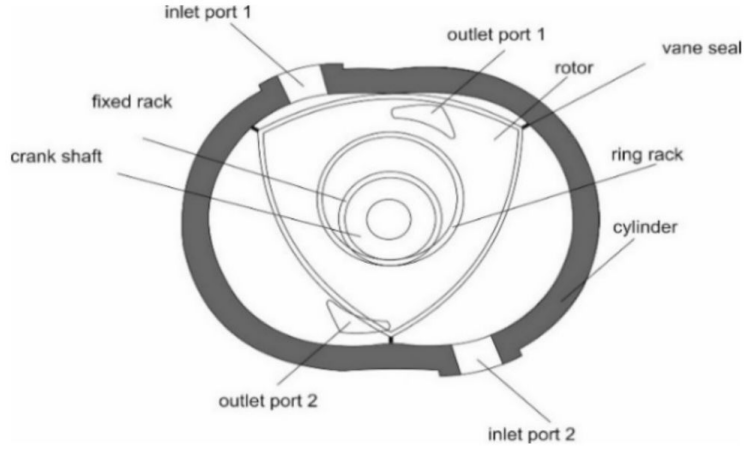

(a)

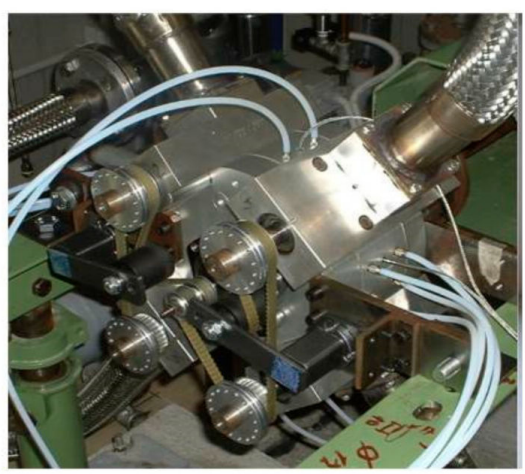

(b)

Figure 40. Design and assembly details of a Wankel expander: (a) cross section of Wankel expander; (b) a general view on Wankel expander [192].

Wankel expanders have a number of advantages when compared to the other positive displacement and turbine expanders. The main advantages of these machines are high power-to-weight ratio, compact design and small external dimensions, lack of reciprocating parts, high rotational speeds, lack of vibrations generated during operation and a small number of moving parts. The main disadvantages of Wankel expanders include piston face seals issues (piston face seals are stressed by temperature variation during the machine operation), piston apex seals issues (piston apex seals are receiving significant loads related to the difference in gas temperature and pressure in adjacent working chambers). At low rotational speeds or low expander load, it is possible that the seal does not fully adhere to the cylinder surface, which may result in an increase of internal gas leakages between adjacent working chambers.

Early works on the possibility of using a Wankel machine as a steam expander were started in 1970s [193-195]. In [195] the results of experimental tests carried out on a Wankel expander using steam as a working fluid were presented. During the tests the steam pressure at the inlet of the expander was varied between 2.76 and $6.5 \mathrm{MPa}$ while the steam temperature was varied between 231 and $410{ }^{\circ} \mathrm{C}$. For these experimental conditions, the obtained expander power was ranging between 12 and $17 \mathrm{~kW}$ and the rotational speed was ranging between 2196 and 2578 rpm. Further works on the application of these machines as steam expanders were carried out in the 1990s [193-195] and are continued currently. In [192] the results of experimental tests of a prototype of Wankel expander designed for steam expansion are reported. The authors developed an expander prototype using parts of a standard Wankel engine (i.e., bearings, shaft and seals were used) and a new specially designed cylinder that was adapted to the supply system consisting of control valves in order to increase expander compression. The view of this prototype is presented 
in Figure $40 \mathrm{~b}$. The valves are controlled by means of a mechanical system based on a timing belt driven from the main expander shaft.

\subsection{Gerotor Expanders}

The other type of volumetric expanders that are used in prototypes of small ORC systems are gerotor expanders [197-199]. The design of this type of volumetric expander is similar to the design of a gear pump. The basic components of gerotor expander are a cylinder and two rotors-internal and external. The internal rotor is assembled on the shaft. The cylinder is closed on both sides by side covers with inlet and outlet ports. The inner rotor is placed eccentrically to the outer rotor. Figure 41 shows the view of the components of the gerotor expander.
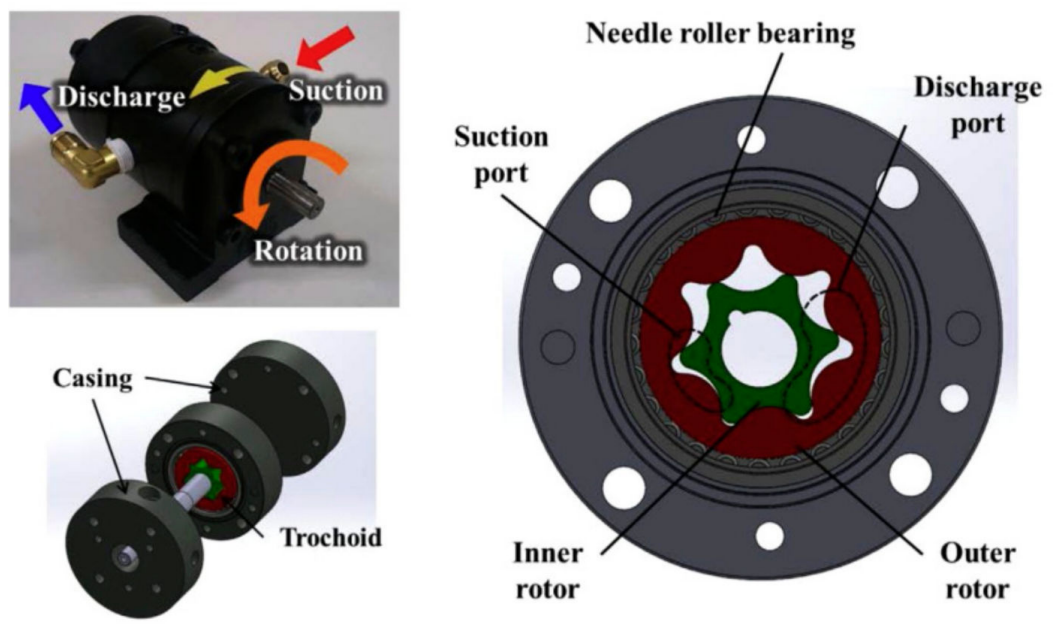

Figure 41. View of the components of the gerotor expander [199].

Gerotor expanders were experimentally tested for their applicability in micro-power ORC systems. In [197] the results of tests on an expander featuring a power output of $1 \mathrm{~kW}$ designed for application in the ORC system using the solar heat were presented. The tests were carried out with the use of the R134a. The pressure of the working fluid at the inlet to the expander was $3.28 \mathrm{MPa}$, while inlet temperatures were varied between 80 and $100{ }^{\circ} \mathrm{C}$. The working fluid pressure at the outlet of the expander was $1.64 \mathrm{MPa}$ and the rotational speed of the expander was $3000 \mathrm{rpm}$. For these experimental conditions, expander power output was ranging between 0.2 and $1 \mathrm{~kW}$ and efficiency was ranging between 35 and 75\%. The optimal expansion ratio was found between 3.0 and 4.0. In [198] the results of experimental tests of three gerotor expanders, which were characterized by different geometrical parameters were presented. These tests were carried out using the ORC system utilizing R123 as a working fluid. The tests were carried out for various parameters of the working fluid at the inlet and outlet of the expander. The working fluid pressure at the inlet to the expanders was varied between 412 and $1878 \mathrm{kPa}$, the working fluid pressure at the outlet of the expanders was varied between 139 and $331 \mathrm{kPa}$, the working fluid temperature at the inlet to the expanders was varied between 84 and $160{ }^{\circ} \mathrm{C}$, while the working fluid temperature at the outlet was varying between 61 and $129^{\circ} \mathrm{C}$. For these experimental conditions, the power output of these expanders was ranging between 0.28 and $2.07 \mathrm{~kW}$ and the achieved efficiency was ranging between 59 and $85 \%$. It was also indicated that, compared to other positive displacement machines, gerotor expanders are characterized by a lower internal friction.

\section{Fuel Cells}

In 1839, British physicist William R. Grove demonstrated that an electrochemical reaction of combining hydrogen with oxygen produces an electric current [200-204]. Such a cell has no moving parts, works noiselessly, and its only waste substance is water. However, 
fuel cells based on this phenomenon were merely a laboratory curiosity for over a century. It was not until the sixties of the last century that NASA started to install light and compact (though expensive) versions in spacecraft to supply them with electricity. Today, this technology, which is promising, ecologically clean, efficient and silent, is being used in many new earthly applications, including powering mobile phones, notebook computers, homes and apartments and electric car engines. Chemical energy is directly converted into electricity in a fuel cell. It is a cell in which the fuel-hydrogen in a pure state or in a mixture with other gases-is fed continuously to the anode, and the oxidant-pure oxygen or a mixture (air) - is fed continuously to the cathode. Electrochemical processes are accompanied by the flow of an electron from the anode to the cathode. The closure of the circuit is carried out by ions that are transferred through the electrolyte. As a result of the electrochemical reaction of hydrogen and oxygen, electricity, water and heat are generated. Reagents are fed continuously to the fuel cell and theoretically it will not discharge; in fact, degradation or component failure will limit the life of any fuel cell.

Most fuel cells use hydrogen to produce electricity and heat [205-209]. Nevertheless, high-temperature fuel cells can run on natural gas due to the possibility of using the socalled internal reforming. The electrical efficiency of modern fuel cells is ca. 40-60 percent.

Different types of fuel cells are developed and are generally classified according to the type of electrolyte used, as it determines the operating temperature of the system and the type of fuel that can be used. The comparison of the different types of fuel cells is presented in Table 1.

Table 1. Comparison of different types of fuel cells [117].

\begin{tabular}{|c|c|c|c|c|}
\hline Fuel Cell Type & $\begin{array}{c}\text { Operating } \\
\text { Temperature }\left({ }^{\circ} \mathrm{C}\right)\end{array}$ & $\begin{array}{c}\text { Power Range } \\
(\mathrm{kW})\end{array}$ & Efficiency (\%) & Application \\
\hline $\begin{array}{c}\text { PEM-Polymer } \\
\text { Electrolite Membrane }\end{array}$ & $60-110$ & $0.01-250$ & $40-55$ & $\begin{array}{l}\text { Portable, Mobile, Low power } \\
\text { generation. }\end{array}$ \\
\hline AFC-Alkaline Fuel Cell & $70-130$ & $0.1-50$ & $50-70$ & Mobile, space, military. \\
\hline PAFC-Phosforic Acid Fuel Cell & $175-210$ & $50-1000$ & $40-45$ & $\begin{array}{l}\text { Medium to large scale power } \\
\text { generation and CHP }\end{array}$ \\
\hline MCFC-Molten Carbonate Fuel Cell & $550-650$ & $200-100,000$ & $50-60$ & $\begin{array}{c}\text { Large scale power generation } \\
\text { Vehicle, }\end{array}$ \\
\hline SOFC-Solid Oxide Fuel Cell & $500-1000$ & $0.5-2000$ & $40-72$ & $\begin{array}{l}\text { medium to large scale power } \\
\text { generation and CHP, } \\
\text { and micro-CHP. }\end{array}$ \\
\hline DMFC-Direct Methanol Fuel Cell & $70-130$ & $0.001-100$ & 40 & Mobile, portable. \\
\hline
\end{tabular}

Fuel cells are used both in small domestic power and heat generating units or auxiliary power sources with a capacity of several dozen kilowatts, as well as in large power plants with a capacity of several megawatts. Small systems with a power of 1-10 kW with fuel cells are able to provide electricity and heat to residential houses, offices and public buildings.

Another advantage is the design based on a modular system, which allows for relatively quick and easy construction of the installation and its possible expansion. Fuel cells are characterized by a high power yield per unit volume of fuel, and at the same time the process of direct conversion of fuel chemical energy into electricity takes place without the emission of toxic components and while maintaining high efficiency of fuel energy use. If the waste heat from the cell installation is used in combined CHP systems, the total energy efficiency may increase even up to 95\% [210-212]. Waste heat can be used for heating, domestic hot water heating, cooling or air conditioning. Hybrid fuel cell installations connected to the gas turbine cycle achieve efficiency of $70 \%$ and more. The dynamic development of fuel cells in recent years means that they are more and more often alternative sources of electricity and heat.

There are many types of fuel cells. They differ mainly in the type of electrolyte, and thus in the operating temperature (see, Table 1). This indirectly also affects the power density that can be taken from the surface of the fuel cell. A Polymer Electrolyte Membrane 
Fuel Cell (PEMFC) and Solid Oxide Fuel Cell (SOFC) are the most popular in small- and micro-generation. PEM fuel cells belong to the group of low temperature fuel cells. Their working temperature does not exceed $100{ }^{\circ} \mathrm{C}$. Their power ranges from a few watts to hundreds of kilowatts. The unquestionable advantage of the operation of these fuel cells is a very quick response to load changes. The disadvantage, however, is the need to use clean fuel due to the platinum catalyst used in this type of fuel cell. An example of a small cogeneration source based on a PEM cell is shown in the Figure 42.

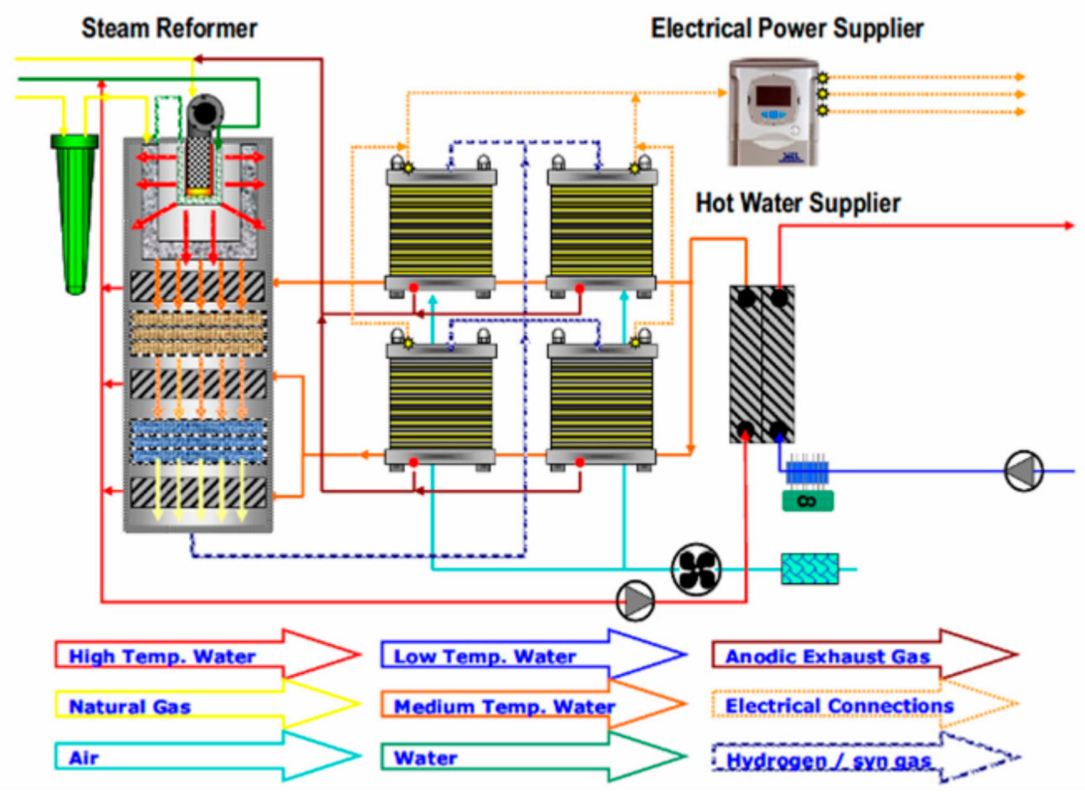

Figure 42. View of the small CHP system based on a Polymer Electrolyte Membrane Fuel Cell (PEM) fuel cell [213].

The system consists of a PEM fuel cell, a methane steam reformer, an inverter, a pump system and a heat exchanger. It produces $36 \mathrm{~kW}$ of electricity and $50 \mathrm{~kW}$ of heat. The system has been built in a container which is divided into mechanical and electrical parts. In the mechanical part there is a reformer and a fuel cell, while in the electrical part there is an inverter and automation and control systems. The view of the container can be seen in the Figure 43.

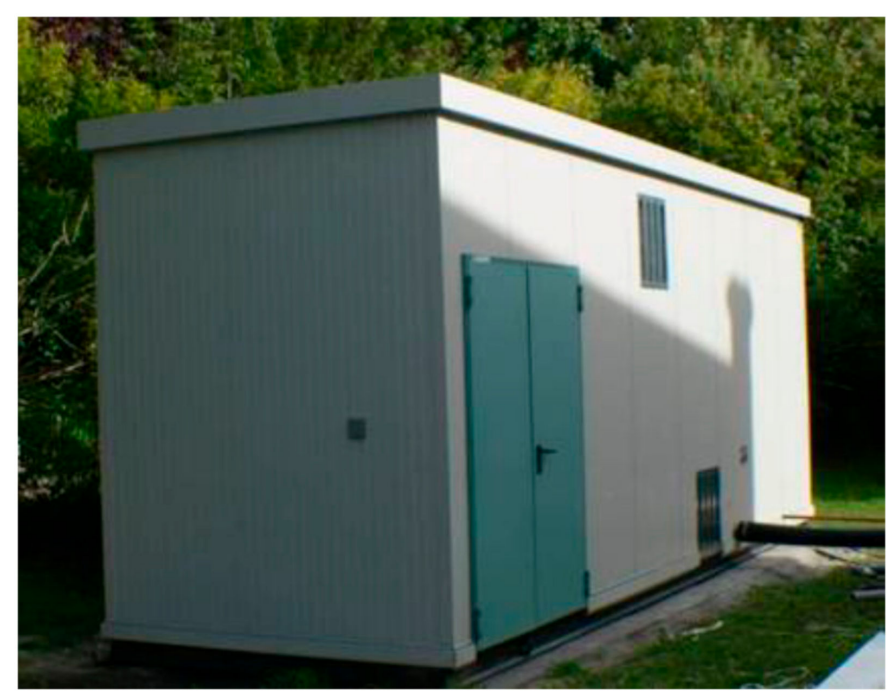

Figure 43. View of the container with $36 \mathrm{~kW}$ PEM fuel cell system [213,214]. 
The most important part of the system is the fuel cell. It is a cell produced by the Canadian company Ballard with a nominal power of $36 \mathrm{~kW}$ and a maximum power of $80 \mathrm{~kW}$. The cell is connected with a fan in order to supply the appropriate amount of oxidant to the reaction process. The fan has high power in relation to the cell's power $(3 \mathrm{~kW})$, which is almost $10 \%$. Figure 44 shows a fuel cell (four stacks at the top) and a fan (below the fuel cell at the bottom).

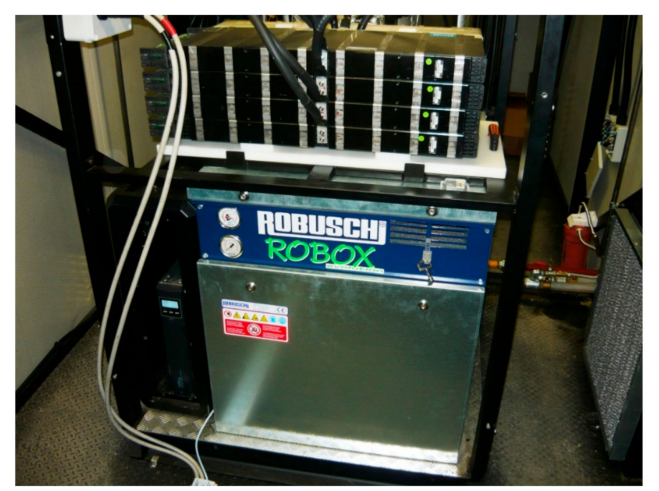

Figure 44. PEM fuel cell with the fan delivering air as an oxidant $[213,214]$.

Another type of fuel cell used in small and micro cogeneration is an SOFC fuel cell. The systems based on this technology offer higher electrical efficiency than the systems based on PEM technology and are especially focused on the continuous operation mode. Contrary to what it was said in the case of PEM cells, which show great keeping up with the demand. In the case of SOFC fuel cells, the surplus electricity is sent to the grid or accumulated if the system is equipped with a battery.

As SOFC fuel cells are one of the most popular types of fuel cells, there have been many studies and publications on combining these fuel cells into systems for the simultaneous generation of electricity and heat. Basic information on such systems can be found in [215-220].

An example of micro cogeneration system based on an SOFC fuel cell is presented in Figure 45.

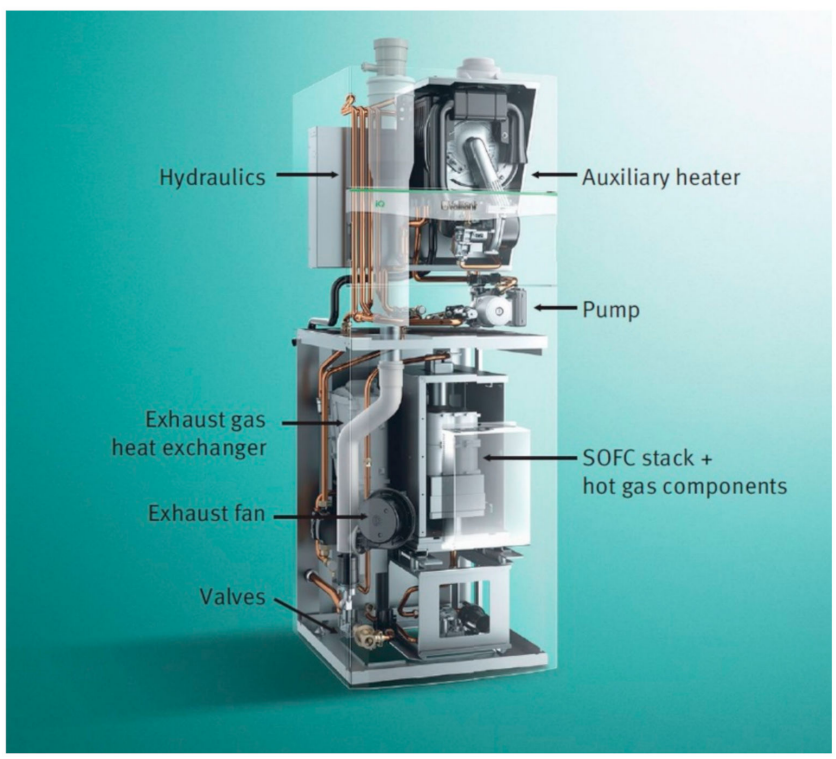

Figure 45. Micro cogeneration system based on a Solid Oxide Fuel Cell (SOFC) fuel cell made by Vaillant [164,221]. 
Due to the high operating temperature $\left(800-1000{ }^{\circ} \mathrm{C}\right)$, SOFC fuel cells can also be combined into systems with other energy sources, such as gas turbines [222-229] and burners [230-235]. An example of an SOFC fuel cell coupled to a gas turbine can be seen in Figure 46, while an SOFC fuel cell coupled to an additional heat source in Figure 47.

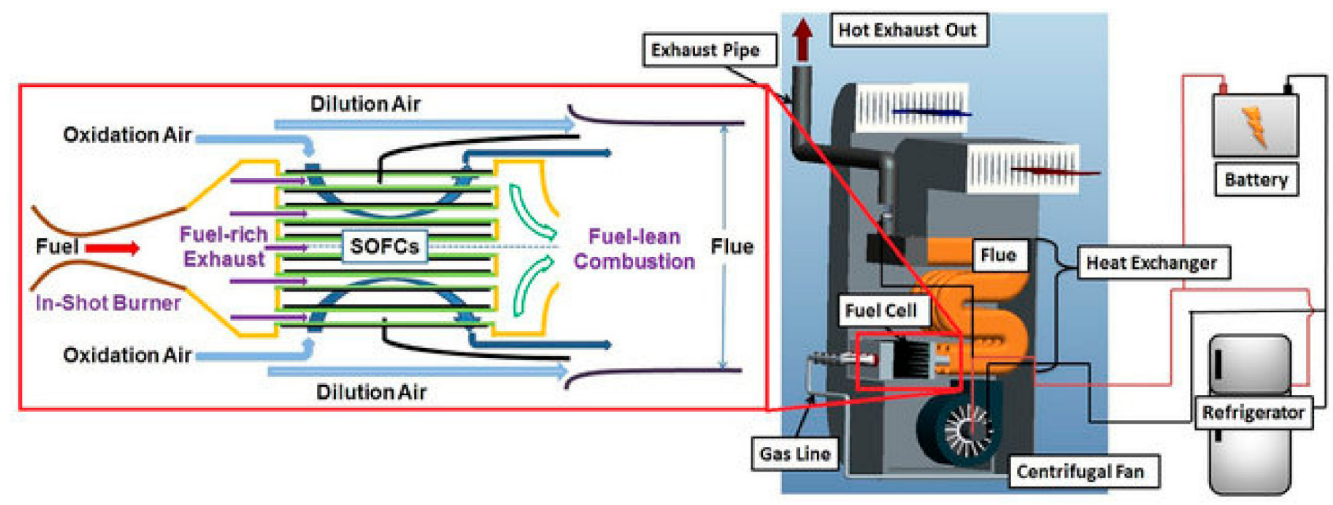

Figure 46. Micro cogeneration system with a flame-assisted SOFC fuel cell [234,235].

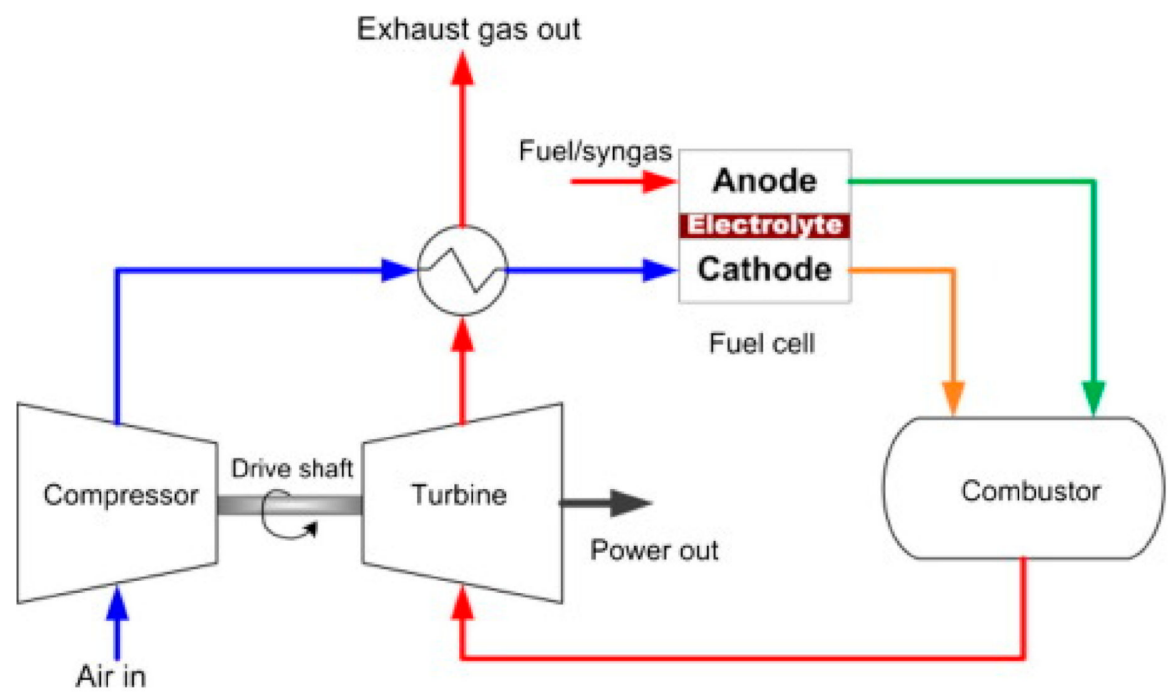

Figure 47. Cogeneration system with an SOFC fuel cell and gas turbine (the so-called hybrid cycle) [229].

The use of the small and microcogeneration systems based on fuel cells in countries where the energy sector is characterized by low $\mathrm{CO}_{2}$ emissions or is largely based on renewable resources will not always bring the expected benefits. Sometimes it can even contribute to the deterioration of the current condition. In the above situation, it is necessary to carry out a detailed profitability analysis for various possible operating modes of the system:

- maximization of generated electricity;

- following the instantaneous demand for electricity;

- maximization of heat production;

- following the instantaneous demand for heat;

- maximization of prosumer profits.

For example, in Scandinavian countries, due to the significant share of renewable energy sources in the energy sector and thus the low emission of harmful compounds, the only economically viable solution is to follow the small and microcogeneration system with instantaneous heat demand. Electricity is a by-product of this operating mode of the system. 


\section{Conclusions}

The article presents an overview of currently used and developed technologies for the production of electricity and heat in the so-called cogeneration (CHP) in small and micro scale. These technologies are becoming more and more popular and needed in relation to the development trend of distributed generation and the so-called virtual power plants. The technologies presented in the article are inter alia, Stirling engines, gas and steam microturbines, various types of volumetric expanders (vane, lobe, screw, piston, Wankel, gerotor), and fuel cells. There is no definite answer as to which of these technologies is the best. Each of them has its advantages and disadvantages and can be adapted to the specific conditions in which it has to operate. These conditions are, for example, the type and availability of fuel, the ability and speed of reaction to load changes, reliability, noise, generated power, environmental and social conditions, availability of service personnel and many others, which should be taken into account when selecting a given technology to meet needs.

Stirling engines are mature technology. Nevertheless, over the years, research centers have been working on their improvement. Microgen company, previously mentioned in the text, has developed an advanced technology that is commercially available. The company does not produce ready-made systems containing a Stirling engine, but supplies engines to system manufacturers. They are used in systems powered by both solid and gaseous fuels. Stirling engines are most often featuring the power output ranging from hundreds of watts to hundreds of kilowatts. In addition to applications in small and micro-cogeneration, Stirling engines can be used in solar energy systems and in the refrigeration industry. These engines are also applied in submarines. Works on their application in cars are ongoing.

The review of the volumetric expanders that are currently applied in small and micro cogeneration systems gave an outlook on their operating conditions and technical details. The following conclusions can be drawn on volumetric expanders basing on the reviewed literature.

- Multi-vane expanders are applied in experimental test-stands of micro CHP ORC systems. The experimental tests were proceeded for working fluid absolute pressure at the inlet to the multi-vane expander ranging between 1.5 and 6.39 bar. The power output of tested multi-vane expanders was ranging between $65 \mathrm{~W}$ and $8 \mathrm{~kW}$, rotational speed was ranging between 1200 and $4100 \mathrm{rpm}$ and isentropic efficiency was ranging between 17.2 and $55.8 \%$. Efficiency of the ORC systems was ranging between 0.75 and $7.65 \%$.

- Rotary lobe expanders are applied in experimental test-stands of small steam plants. The working fluid pressure at the inlet to the rotary lobe expander ranges between 8 and 40 bar. The working fluid pressure at the inlet should not exceed $350{ }^{\circ} \mathrm{C}$ due to sealing problems. The power output of these machines ranges from single kilowatts up to ca. $150 \mathrm{~kW}$ for a single stage expander. Lobe expanders were also applied in solar-powered ORCs.

- Root expanders are applied in experimental test-stands of micro CHP ORC systems. The experimental tests were proceeded for working fluid pressure at the inlet to the Roots expander ranging between 3 and 10.8 bar. The working fluid pressure at the outlet of the machine was ranging between 1.35 and 2.25 bar. The power output of tested Roots expanders was ranging between $100 \mathrm{~W}$ and $3 \mathrm{~kW}$. The rotational speed of the expander was varying between 1500 and $11000 \mathrm{rpm}$. The highest expander isentropic efficiency of ca. $50 \%$ was obtained.

- Screw expanders are successfully applied in commercially available steam and ORC $\mathrm{CHP}$ systems. They can operate in different conditions. The absolute pressure of the working fluid at the inlet to the screw expander is ranging between 3 and 25 bar, while the temperature of the heat sources is ranging between 90 and $540{ }^{\circ} \mathrm{C}$. The power output of these systems ranges between few $\mathrm{kW}$ and $630 \mathrm{~kW}$ while efficiency of the ORC systems adopting screw expanders ranges between 5 and $10 \%$. 
- $\quad$ Single-screw expanders are applied in experimental test-stands of small steam and ORC CHP plants. The experimental tests were proceeded for working fluid absolute pressure at the inlet to the screw expander ranging between 3 and $6.75 \mathrm{bar}$, and the temperature of the heat sources ranging between 80 and $120^{\circ} \mathrm{C}$. The power output of these expanders ranges between $5 \mathrm{~kW}$ and $172 \mathrm{~kW}$, rotational speed ranges between 2000 and $3000 \mathrm{rpm}$, obtained efficiency of the expanders ranges between 10 and $66 \%$ while efficiency of the ORC systems adopting single-screw expanders ranges between 7.98 and $9.3 \%$.

- Piston expanders are applied in experimental test-stands of small steam and ORC CHP plants. The experimental tests were proceeded for working fluid absolute pressure at the inlet to the piston expander ranging between 11 and 34 bar and the inlet temperature of the working fluid ranging between 65 and $340^{\circ} \mathrm{C}$. The power output of these expanders ranges between $0.25 \mathrm{~kW}$ and $3 \mathrm{~kW}$, rotational speed ranges between $320 \mathrm{rpm}$ and $4000 \mathrm{rpm}$ and expanders efficiency ranges between 55 and $70 \%$.

- Linear piston expanders are applied in experimental test-stands of ORC CHP plants. The experimental tests were proceeded for working fluid absolute pressure at the inlet to the linear piston expander ranging between 13 and 21 bar. The maximum power output of $22.7 \mathrm{~W}$ was obtained in case of these expanders, and internal efficiency was ranging between 66.2 and $93 \%$.

- Wankel expanders are applied in experimental test-stands of steam plants. The experimental tests were proceeded for working fluid absolute pressure at the inlet to the Wankel expander ranging between 27.6 and 65 bar and the temperature of the working fluid ranging between $231-410{ }^{\circ} \mathrm{C}$. The power output of Wankel expanders ranges between 12 and $17 \mathrm{~kW}$ and rotational speed ranges between 2196 and $2578 \mathrm{rpm}$.

- Gerotor expanders are applied in experimental test-stands of ORC plants. The experimental tests were proceeded for working fluid absolute pressure at the inlet to the gerotor expander ranging between 27.6 and 65 bar and the temperature of the working fluid ranging between 80 and $160{ }^{\circ} \mathrm{C}$. The power output of Wankel expanders ranges between 0.2 and $2.07 \mathrm{~kW}$, rotational speed was equal to $3000 \mathrm{rpm}$ and obtained efficiency of the expanders ranges between 35 and $85 \%$.

Both gas and steam microturbines are mature technology dating back several dozen years. Research on microturbines is carried out in scientific units around the world, but more often they result from attempts to use ready-made microturbines from well-known manufacturers for use in systems with their participation. There are few research centers that deal with the design of microturbines alone. As a mature technology, microturbines are used mainly in small and industrial microcogeneration. This technology is not used in households, mainly due to the costs and noise generated by microturbines. Due to the nature of their construction, they are high-speed machines. In addition to the noise generated, this has an impact on problems in the use of generators (a gear or a high-speed generator is necessary). The power range of microturbines is in the range of hundreds of watts to several hundred kilowatts. Their efficiency is $20-30 \%$ for gas microturbines (electrical efficiency) and 60-70\% for steam microturbines (internal efficiency). It should be noted that the gas microturbine can work as an independent device for the supply of fuel, and in the case of a steam microturbine it must be part of the system (e.g., the Rankine cycle) and then the system's electrical efficiency should be taken as an output parameter of the system, which is ca. $20 \%$.

Fuel cells are a commercialized technology. The most common types of cells used in microcogeneration are PEM fuel cells and SOFC fuel cells. The first one is a fully mature technology and commercially produced in the power range from a few watts to hundreds of kilowatts. They are characterized by a quick start-up and low operating temperature, and hence high flexibility in terms of load change. The problem is the fuel that should be clean ( $\mathrm{CO}$ free) due to the platinum catalytic converter. It requires the use of pure hydrogen, e.g., from the electrolysis process, or, if it comes from other processes, such as methane steam reforming-purifying it. As for SOFC fuel cells, they are also a 
relatively mature technology. Unfortunately, the problem is the complicated production process that involves sintering components together. Scientific centers conduct research on the improvement of components (electrodes and electrolyte) in order to achieve better performance, but the finished devices are manufactured and sold, especially in Asian countries. The disadvantage is the high operating temperature, which is associated with a longer start-up and the need for more stable operation when it comes to changing loads. In practice, devices with a power of several hundred watts to hundreds of kilowatts are the most popular. The authors of this article believe that the long-observed trend towards decentralizing the production of electricity and heat will contribute to even more dynamic development of small and micro technologies in the CHP sector.

It is also important that most of the technologies presented here can be used to use waste heat from industrial plants. As a result of electricity and heat generation processes or other technological processes taking place in industrial plants, some energy is irretrievably lost to the environment. Especially in small and medium-sized industrial plants, energy and environmental awareness are at a low level. These plants were often built a long time ago, have old machinery and are located in energy-inefficient halls and buildings. The application of the systems presented here can contribute to the improvement of energy efficiency thanks to the recovery of waste heat. Thanks to their positive features and utilization of high-quality fuels, domestic micro CHP systems can possibly contribute to the significant reduction of the amount of pollutants emitted into the environment from standard heating systems. Standard furnaces that are often used for heating the houses during winter are often low-efficient and fed by low-quality fuels. Therefore, worse and worse air quality is being observed in many countries. Many of the currently applied furnaces can be successfully replaced with domestic CHP units based on the technologies described in this article. In this way, their application may have a positive influence on air quality.

Author Contributions: Conceptualization, M.W.; writing—original draft preparation, M.W. and P.K.; writing - review and editing, P.K., M.W. and K.B.; visualization, M.W. and P.K.; project administration, K.B.; funding acquisition, K.B. All authors have read and agreed to the published version of the manuscript.

Funding: This research received no external funding.

Acknowledgments: The authors would like to thank the Scientific Council of the Discipline of Environmental Engineering, Mining and Power Engineering and the Dean of the Faculty of Power and Aeronautical Engineering of the Warsaw University of Technology for their support. The publication is the result of an Internal Grant for employees of the Warsaw University of Technology in 2020 .

Conflicts of Interest: The authors declare no conflict of interest.

\section{References}

1. Capuano, D.L. Energy Information Administration; Annual Energy Outlook: Washington, DC, USA, 2020.

2. Aymar, R.; Barabaschi, P.; Shimomura, Y. The ITER design. Plasma Phys. Control. Fusion 2002, 44, 519-565. [CrossRef]

3. Opriş̧, I.; Cenuşă, V.; Norişor, M.; Darie, G.; Alexe, F.-N.; Costinaş, S. Parametric optimization of the thermodynamic cycle design for supercritical steam power plants. Energy Convers. Manag. 2020, 208, 112587. [CrossRef]

4. Garievskii, M. Optimization of CCGT operating modes at variable loads taking into account equivalent operating hours. J. Phys. 2020, 1683, 042022.

5. Alanne, K.; Saari, A. Distributed energy generation and sustainable development. Renew. Sustain. Energy Rev. 2006, 10, 539-558. [CrossRef]

6. Wang, X.; Shu, G.; Yan, F.; Feng, W.; Wang, R.; Pan, J. Optimization of a distributed energy system with multiple waste heat sources and heat storage of different temperatures based on the energy quality. Appl. Therm. Eng. 2020, 181, 115975. [CrossRef]

7. Luo, Z.; Yang, S.; Xie, N.; Xie, W.; Liu, J.; Agbodjan, Y.S.; Liu, Z. Multi-objective capacity optimization of a distributed energy system considering economy, environment and energy. Energy Convers. Manag. 2019, 200, 112081. [CrossRef]

8. Lowitzsch, J.; Hoicka, C.E.; Van Tulder, F.J. Renewable energy communities under the 2019 European Clean Energy PackageGovernance model for the energy clusters of the future? Renew. Sustain. Energy Rev. 2020, 122, 109489. [CrossRef] 
9. Rosato, A.; Sibilio, S. Performance assessment of a micro-cogeneration system under realistic operating conditions. Energy Convers. Manag. 2013, 70, 149-162. [CrossRef]

10. Rosato, A.; Sibilio, S.; Ciampi, G. Energy, environmental and economic dynamic performance assessment of different microcogeneration systems in a residential application. Appl. Therm. Eng. 2013, 59, 599-617. [CrossRef]

11. Rosato, A.; Sibilio, S. Energy performance of a micro-cogeneration device during transient and steady-state operation: Experiments and simulations. Appl. Therm. Eng. 2013, 52, 478-491. [CrossRef]

12. Rosato, A.; Sibilio, S. Calibration and validation of a model for simulating thermal and electric performance of an internal combustion engine-based micro-cogeneration device. Appl. Therm. Eng. 2012, 45, 79-98. [CrossRef]

13. De Paepe, M.; Mertens, D. Combined heat and power in a liberalised energy market. Energy Convers. Manag. 2007, 48, 2542-2555. [CrossRef]

14. De Paepe, M.; D’Herdt, P.; Mertens, D. Micro-CHP systems for residential applications. Energy Convers. Manag. 2006, 47, 3435-3446. [CrossRef]

15. Pehnt, M. Environmental impacts of distributed energy systems-The case of micro cogeneration. Environ. Sci. Policy 2008, 11, 25-37. [CrossRef]

16. Pehnt, M.; Fischer, C. Environmental Impacts of Micro Cogeneration. In Micro Cogeneration; Springer Nature: Berlin/Heidelberg, Germany, 2006; pp. 87-116.

17. Dowson, D. Men of Tribology: Guillaume Amontons (1663-1705) and John Theophilus Desaguliers (1683-1744). J. Lubr. Technol. 1978, 100, 2-5. [CrossRef]

18. Talbot, G.R.; Pacey, A.J. Antecedents of Thermodynamics in the Work of Guillaume Amontons. Centaurus 1972, 16, 20-40. [CrossRef]

19. Guillaume, A. Ciencias Químicas. Rev. CENIC 2005, 36, 187-195.

20. Woerlen, I. Hot Air Engines. Available online: www.hotairengines.org (accessed on date 20 December 2020).

21. Cayley, S.G.; Gordon, A.; Gurney, G.; Brunel, I.K.; Stephenson, R. Discussion. Sir George Cayley's Hot-Air Engine. (Includes Plate). In Minutes of the Proceedings of the Institution of Civil Engineers; Thomas Telford Ltd.: London, UK, 1850; Volume 9, pp. $9197-9203$.

22. Gibbs-Smith, C.H. Sir George Cayley* 'Father of aerial navigation' (1773-1857). Notes Rec. R. Soc. 1962, 17, 36-56. [CrossRef]

23. Cooke, C.W. On Wenham's Heated-Air Engine. Proc. Inst. Mech. Eng. 1873, 24, 63-86. [CrossRef]

24. Stirling International. Available online: www.stirlinginternational.org (accessed on 20 December 2020).

25. Harlow, H.F. Hot Air Engines. Sci. Am. 1852, 7, 293. [CrossRef]

26. Zanzig, J. The Stirling Cycle Engine; SAE Technical Paper Series; SAE International: Warrendale, PA, USA, 1963.

27. Otaka, T. Stirling Engines, Their History and Basic Theories. J. Inst. Electr. Eng. Jpn. 2016, 136, 596-600. [CrossRef]

28. Kazmierczak, J.; Zmudzki, S. Relative Analysis of free-Piston Stirling Engine Dynamics. J. Propulsion Power $1986,2,505-513$.

29. Moscrip, W. The Moscrip-Stirling engine-A new departure. In Proceedings of the Intersociety Energy Conversion Engineering Conference, San Francisco, CA, USA, 19 August 1984.

30. Szałwiński, P. Silnik Stirlinga i Możliwości Jego Zastosowania w Energetyce; European Union funded Research Grant; Wrocław University of Science and Technolgy: Wrocław, Poland, 2010.

31. Walker, G. Elementary Design Guidelines for Stirling Engines. Proc. Intersoc. Energy Convers. Eng. Conf. 1979, 1, $1066-1068$.

32. Walker, G.C.; Senft, J.R. Free Piston Stirling Engines. Lecture Notes in Engineering; Springer Verlag: Berlin/Heidelberg, Germany, 1985; ISBN 978-3-642-82526-2.

33. Karabulut, H.; Yücesu, H.S.; Koca, A. Manufacturing and testing of a V-type Stirling engine. Turkish. J. Eng. Environ. Sci. 2000, 24, 71-80.

34. Yoshihara, S.; Hoshino, T. Model free piston Stirling engine. In Proceedings of the Symposium on Stirlling Cycle, Japan Society of Mechanical Engineers, Tokyo, Japan, 17-18 October 2003; pp. 87-88.

35. Żmudzki, S. Silniki Stirlinga; WNT—Wydawnictwa Naukowo-Techniczne: Warsaw, Poland, 1993.

36. Rahmati, A.; Varedi-Koulaei, S.M.; Ahmadi, M.H.; Ahmadi, H. Dimensional synthesis of the Stirling engine based on optimizing the output work by evolutionary algorithms. Energy Rep. 2020, 6, 1468-1486. [CrossRef]

37. Thombare, D.G.; Umale, N. Theoretical Analysis of Effect of Regenerator Geometry and Material on Stirling Engine Performance. In Proceedings of the 1st National, P.G. Conference RIT NCon PG-2015, Sangli, Maharashtra, India, 1 June 2015.

38. Thombare, D.G.; Karmare, S.V. Theoretical and experimental investigation of Alfa type bio mass Stirling engine with effect of regenerator effectiveness, heat transfer, and properties of working fluid. J. Renew. Sustain. Energy 2012, 4, 43126. [CrossRef]

39. Karabulut, H.; Okur, M.; Halis, S.; Altin, M. Thermodynamic, dynamic and flow friction analysis of a Stirling engine with Scotch yoke piston driving mechanism. Energy 2019, 168, 169-181. [CrossRef]

40. Bulinski, Z.; Szczygieł, I.; Krysiński, T.; Stanek, W.; Czarnowska, L.; Gładysz, P.; Kabaj, A. Finite time thermodynamic analysis of small alpha-type Stirling engine in non-ideal polytropic conditions for recovery of LNG cryogenic exergy. Energy 2017, 141, 2559-2571. [CrossRef]

41. Kropiwnicki, J. Analysis of start energy of Stirling engine type alpha. Arch. Thermodyn. 2019, 40, 243-259. [CrossRef]

42. Bataineh, K. Mathematical formulation of alpha -type Stirling engine with Ross Yoke mechanism. Energy 2018, 164, 1178-1199. [CrossRef]

43. Almajri, A.K.; Mahmoud, S.; Al-Dadah, R. Modelling and parametric study of an efficient Alpha type Stirling engine performance based on 3D CFD analysis. Energy Convers. Manag. 2017, 145, 93-106. [CrossRef] 
44. Altin, M.; Okur, M.; Ipci, D.; Halis, S.; Karabulut, H. Thermodynamic and dynamic analysis of an alpha type Stirling engine with Scotch Yoke mechanism. Energy 2018, 148, 855-865. [CrossRef]

45. Ipci, D.; Karabulut, H. Thermodynamic and dynamic analysis of an alpha type Stirling engine and numerical treatment. Energy Convers. Manag. 2018, 169, 34-44. [CrossRef]

46. Bataineh, K.M. Numerical thermodynamic model of alpha-type Stirling engine. Case Stud. Therm. Eng. 2018, 12, 104-116. [CrossRef]

47. Cinar, C.; Yücesu, H.S.; Topgül, T.; Okur, M. Beta-type Stirling engine operating at atmospheric pressure. Appl. Energy 2005, 81, 351-357. [CrossRef]

48. Solmaz, H.; Ardebili, S.M.S.; Aksoy, F.; Calam, A.; Yılmaz, E.; Arslan, M. Optimization of the operating conditions of a beta-type rhombic drive stirling engine by using response surface method. Energy 2020, 198, 117377. [CrossRef]

49. Chahartaghi, M.; Sheykhi, M. Thermal modeling of a trigeneration system based on beta-type Stirling engine for reductions of fuel consumption and pollutant emission. J. Clean. Prod. 2018, 205, 145-162. [CrossRef]

50. Uchman, W.; Remiorz, L.; Grzywnowicz, K.; Kotowicz, J. Parametric analysis of a beta Stirling engine-A prime mover for distributed generation. Appl. Therm. Eng. 2018, 145, 693-704. [CrossRef]

51. Shendage, D.; Kedare, S.B.; Bapat, S. An analysis of beta type Stirling engine with rhombic drive mechanism. Renew. Energy 2011, 36, 289-297. [CrossRef]

52. Chahartaghi, M.; Sheykhi, M. Energy and exergy analyses of beta-type Stirling engine at different working conditions. Energy Convers. Manag. 2018, 169, 279-290. [CrossRef]

53. Ahmed, F.; Huang, H.; Khan, A.M. Numerical modeling and optimization of beta-type Stirling engine. Appl. Therm. Eng. 2019, 149, 385-400. [CrossRef]

54. Caetano, B.C.; Lara, I.F.; Borges, M.U.; Sandoval, O.R.; Valle, R.M. A novel methodology on beta-type Stirling engine simulation using CFD. Energy Convers. Manag. 2019, 184, 510-520. [CrossRef]

55. Sowale, A.; Kolios, A.; Onabanjo, T.; Somorin, T.; Parker, A.; Williams, L.; Collins, M.; McAdam, E.; Tyrrel, S. Thermodynamic analysis of a gamma type Stirling engine in an energy recovery system. Energy Convers. Manag. 2018, 165, 528-540. [CrossRef]

56. Alfarawi, S.; Al-Dadah, R.; Mahmoud, S. Enhanced thermodynamic modelling of a gamma-type Stirling engine. Appl. Therm. Eng. 2016, 106, 1380-1390. [CrossRef]

57. Katooli, M.H.; Moghadam, R.A.; Hooshang, M. Investigation on effective operating variables in gamma-type Stirling engine performance: A simulation approach. SN Appl. Sci. 2020, 2, 1-7. [CrossRef]

58. Gheith, R.; Aloui, F.; Tazerout, M.; Ben Nasrallah, S. Experimental investigations of a gamma Stirling engine. Int. J. Energy Res. 2011, 36, 1175-1182. [CrossRef]

59. Araoz, J.A.; Cardozo, E.; Salomon, M.; Alejo, L.; Fransson, T.H. Development and validation of a thermodynamic model for the performance analysis of a gamma Stirling engine prototype. Appl. Therm. Eng. 2015, 83, 16-30. [CrossRef]

60. Hooshang, M.; Moghadam, R.A.; Alizadehnia, S. Dynamic response simulation and experiment for gamma-type Stirling engine. Renew. Energy 2016, 86, 192-205. [CrossRef]

61. Vahid, D.J.; Oskouei, H.D. Design and anylysis of gamma type Stirling engine. Mech. Ind. 2020, 21, 511. [CrossRef]

62. Parlak, N.; Wagner, A.; Elsner, M.; Soyhan, H.S. Thermodynamic analysis of a gamma type Stirling engine in non-ideal adiabatic conditions. Renew. Energy 2009, 34, 266-273. [CrossRef]

63. Damirchi, H.; Najafi, G.; Alizadehnia, S.; Mamat, R.; Azwadi, C.S.N.; Azmi, W.; Noor, M. Micro Combined Heat and Power to provide heat and electrical power using biomass and Gamma-type Stirling engine. Appl. Therm. Eng. 2016, 103, 1460-1469. [CrossRef]

64. Li, R.; Grosu, L.; Li, W. New polytropic model to predict the performance of beta and gamma type Stirling engine. Energy 2017, 128, 62-76. [CrossRef]

65. Egas, J.; Clucas, D. Stirling Engine Configuration Selection. Energies 2018, 11, 584. [CrossRef]

66. Microgen Engine Corporation. Available online: www.microgen-engine.com (accessed on 20 December 2020).

67. Li, T.; Tang, D.; Li, Z.; Du, J.; Zhou, T.; Jia, Y. Development and test of a Stirling engine driven by waste gases for the micro-CHP system. Appl. Therm. Eng. 2012, 33-34, 119-123. [CrossRef]

68. Zhu, S.; Yu, G.; Jongmin, O.; Xu, T.; Wu, Z.; Dai, W.; Luo, E. Modeling and experimental investigation of a free-piston Stirling engine-based micro-combined heat and power system. Appl. Energy 2018, 226, 522-533. [CrossRef]

69. Khoshbazan, M.; Ahmadi, M.H.; Ming, T.; Arjmand, J.T.; Ahmadi, M.H. Thermo-economic analysis and multi-objective optimization of micro-CHP Stirling system for different climates of Iran. Int. J. Low-Carbon Technol. 2018, 13, 388-403. [CrossRef]

70. Cardozo, E.; Malmquist, A. Performance comparison between the use of wood and sugarcane bagasse pellets in a Stirling engine micro-CHP system. Appl. Therm. Eng. 2019, 159, 113945. [CrossRef]

71. Napitupulu, F.H.; Ambarita, H. Manufacturing and testing prototype of a gamma type Stirling engine for micro-CHP application. IOP Conf. Ser. Mater. Sci. Eng. 2020, 725, 012016.

72. Stamford, L.; Greening, B.; Azapagic, A. Life cycle environmental and economic sustainability of Stirling engine micro-CHP systems. Energy Technol. 2018, 6, 1119-1138. [CrossRef]

73. Chmielewski, A.; Gumiński, R.; Lubikowski, K.; Maczak, J.; Szulim, P. Badania układu mikrokogeneracyjnego z silni-kiem stirlinga. Czȩść, II. Rynek Energ. 2015, 119, 42-48. 
74. Chmielewski, A.; Lubikowski, K.; Radkowski, S. Badania Temperaturowe i Analiza Współpracy UKładu Mikro-kogeneracyjnego z Silnikiem Gazowym. Rynek Energ. 2015, 118, 56-63.

75. Janowski, T.; Nalewaj, K.; Holuk, M. Układ kogeneracyjny z silnikiem Stirlinga. Prz. Elektrotech. 2014, 90, 63-64. [CrossRef]

76. Viessmann Group. We Create Living Spaces for Generations to Come. Available online: www.wiessmann.com (accessed on 20 December 2020).

77. Wołowicz, M. Silnik Stirlinga jako element układów mikrokogeneracyjnych. Rynek Energii. 2020, 5, 27-32.

78. Okofen Forschungs- und Entwicklungs Ges.m.b.H. Available online: www.oekofen.com (accessed on 20 December 2020).

79. Alberti, F.; Crema, L. Design of a New Medium-temperature Stirling Engine for Distributed Cogeneration Applications. Energy Proced. 2014, 57, 321-330. [CrossRef]

80. Crema, L.; Alberti, F.; Bertaso, A.; Bozzoli, A. Development of a pellet boiler with Stirling engine for m-CHP domestic application. Energy Sustain. Soc. 2011, 1, 5. [CrossRef]

81. Qiu, S.; Gao, Y.; Rinker, G.; Yanaga, K. Development of an advanced free-piston Stirling engine for micro combined heating and power application. Appl. Energy 2019, 235, 987-1000. [CrossRef]

82. Solomon, L.; Qiu, S. Computational analysis of external heat transfer for a tubular Stirling convertor. Appl. Therm. Eng. 2018, 137, 134-141. [CrossRef]

83. Grosu, L.; Dobre, C.; Petrescu, S. Study of a Stirling engine used for domestic micro-cogeneration. Thermodynamic analysis and experiment. Int. J. Energy Res. 2015, 39, 1280-1294. [CrossRef]

84. Mangion, R.; Muscat, M.; Sant, T.; Rizzo, J.; Ghirlando, R.; Cilia, J.; Mizzi, J.; Vural, S. Challenges in Developing a Solar Powered Stirling Engine for Domestic Electricity Generation. In Proceedings of the 9th International Conference on Heat Transfer, Fluid Mechanics and Thermodynamics, Malta, 16-18 July 2012; pp. 785-794.

85. González-Pino, I.; Pérez-Iribarren, E.; Campos-Celador, A.; Terés-Zubiaga, J.; Las-Heras-Casas, J. Modelling and experimental characterization of a Stirling engine-based domestic micro-CHP device. Energy Convers. Manag. 2020, 225, 113429. [CrossRef]

86. Jabari, F.; Mohammadi-Ivatloo, B.; Sharifian, M.B.B.; Nojavan, S. Design and robust optimization of a novel industrial continuous heat treatment furnace. Energy 2018, 142, 896-910. [CrossRef]

87. Zevenhoven, R.; Khan, U.; Haikarainen, C.; Saeed, L.; Tveit, T.M.; Saxén, H. Performance improvement of an indus-trial Stirling engine heat pump. In Proceedings of the ECOS 2020-33rd International Conference on Efficiency, Cost, Optimization, Simulation and Environmental Impact of Energy Systems, Osaka, Japan, 29 June-3 July 2020; pp. 1042-1053.

88. Dinesh, K.; Gowtham Raj, R.; Naresh, M.; Rakesh, N.; Sriram, R. Design and Fabrication Of Low Cost Stirling Engine For Low Duty Industrial Applications. Int. J. Sci. Technol. Res. 2014, 3, 75-78.

89. Alphonse, M.; Kumar, R.R.; Kumar, M.S.; Karthik, K. Design and thermal analysis of stirling engine using industrial applications of ceramic material. Int. J. Mech. Eng. Technol. 2017, 8, 273-282.

90. Gaddamwar, S.S.; Pawar, A.N.; Naik, P.A. Tjprc An Optimization of High Pressure and Temperature of SYNGAS in Underground Coal Mines by using CFD Analysis of Membrane Serpentine Tube. Int. J. Mech. Prod. Eng. Res. Dev. 2019, 9, 617-624. [CrossRef]

91. Jabari, F.; Nojavan, S.; Mohammadi-Ivatloo, B.; Ghaebi, H.; Mehrjerdi, H. Risk-constrained scheduling of solar Stirling engine based industrial continuous heat treatment furnace. Appl. Therm. Eng. 2018, 128, 940-955. [CrossRef]

92. Farsakoglu, O.F.; Alahmad, A. Comprehensive Design of Stirling Engine Based Solar Dish Power Plant with Solar Tracking System. J. Electr. Electron. Syst. 2018, 7, 1-5. [CrossRef]

93. Khosravi, A.; Syri, S.; Pabón, J.J.; Sandoval, O.R.; Caetano, B.C.; Barrientos, M.H. Energy modeling of a solar dish/Stirling by artificial intelligence approach. Energy Convers. Manag. 2019, 199, 112021. [CrossRef]

94. Das, D.C.; Sinha, N.; Roy, A. Small signal stability analysis of dish-Stirling solar thermal based autonomous hybrid energy system. Int. J. Electr. Power Energy Syst. 2014, 63, 485-498. [CrossRef]

95. Buscemi, A.; Brano, V.L.; Chiaruzzi, C.; Ciulla, G.; Kalogeri, C. A validated energy model of a solar dish-Stirling system considering the cleanliness of mirrors. Appl. Energy 2020, 260. [CrossRef]

96. Rahman, A.; Saikia, L.C.; Sinha, N. Automatic generation control of an interconnected two-area hybrid thermal system considering dish-stirling solar thermal and wind turbine system. Renew. Energy 2017, 105, 41-54. [CrossRef]

97. Mocanu, D.-A.; Badescu, V.; Bucur, C.; Stefan, I.; Carcadea, E.; Răboacă, M.S.; Manta, I. PLC Automation and Control Strategy in a Stirling Solar Power System. Energies 2020, 13, 1917. [CrossRef]

98. Kongtragool, B.; Wongwises, S. A review of solar-powered Stirling engines and low temperature differential Stirling engines. Renew. Sustain. Energy Rev. 2003, 7, 131-154. [CrossRef]

99. Lai, X.; Yu, M.; Long, R.; Liu, Z.; Liu, W. Dynamic performance analysis and optimization of dish solar Stirling engine based on a modified theoretical model. Energy 2019, 183, 573-583. [CrossRef]

100. Gao, X.; Shen, J.; He, X.; Tang, C.; Li, K.; Dai, W.; Li, Z.; Jia, J.; Gong, M.; Wu, J.F. Improvements of a room-temperature magnetic refrigerator combined with Stirling cycle refrigeration effect. Int. J. Refrig. 2016, 67, 330-335. [CrossRef]

101. Ahmadi, M.H.; Ahmadi, M.A.; Maleki, A.; Pourfayaz, F.; Bidi, M.; Açıkkalp, E. Exergetic sustainability evaluation and multiobjective optimization of performance of an irreversible nanoscale Stirling refrigeration cycle operating with Maxwell-Boltzmann gas. Renew. Sustain. Energy Rev. 2017, 78, 80-92. [CrossRef]

102. Suranjan, S.; John, J.S.; Mathew, A.J.; Jose, J.; Joshy, G.; Ramesh, A.; Sachidananda, H.K. Determination of coefficient of performance of stirling refrigeration sm. Int. J. Innov. Technol. Explor. Eng. 2019, 8, 2522-2529. [CrossRef] 
103. Yin, Y.; Chen, L.; Wu, F. Performance analysis and optimization for generalized quantum Stirling refrigeration cycle with working substance of a particle confined in a general 1D potential. Phys. E Low-Dimens. Syst. Nanostruct. 2018, 97, 57-63. [CrossRef]

104. Djetel-Gothe, S.; Lanzetta, F.; Bégot, S. Second law analysis for the experimental performances of a cold heat exchanger of a stirling refrigeration machine. Entropy 2020, 22. [CrossRef]

105. Wadaskar, N.N.; Choudhary, S.K.; Askhedkar, R.D. Generation of heat transfer coefficient data in regenerator for stirling cycle refrigeration system. Int. J. Eng. Adv. Technol. 2019, 8, 698-705. [CrossRef]

106. Djetel-Gothe, S.; Bégot, S.; Lanzetta, F.; Gavignet, E. Design, manufacturing and testing of a Beta Stirling machine for refrigeration applications. Int. J. Refrig. 2020, 115, 96-106. [CrossRef]

107. Nie, W.; He, J.; Du, J. Performance characteristic of a Stirling refrigeration cycle in micro/nano scale. Phys. A Stat. Mech. Appl. 2009, 388, 318-324. [CrossRef]

108. Getie, M.Z.; Lanzetta, F.; Bégot, S.; Admassu, B.T.; Hassen, A.A. Reversed regenerative Stirling cycle machine for refrigeration application: A review. Int. J. Refrig. 2020, 118, 173-187. [CrossRef]

109. Sanaye, S.; Ardali, M.R. Estimating the power and number of microturbines in small-scale combined heat and power systems Appl. Energy 2009, 86. [CrossRef]

110. Marcellan, A. An Exploration into the Potential of Microturbine Based Propulsion Systems for Civil Unmanned Aerial Vehicles. Master's Thesis, Faculty of Aerospace Engineering, Delft University of Technology (TU Delft), Delft, The Netherlands, 2015.

111. Ribau, J.; Silva, C.; Brito, F.P.; Martins, J. Analysis of four-stroke, Wankel, and microturbine based range extenders for electric vehicles. Energy Convers. Manag. 2012, 58. [CrossRef]

112. Soares, C. Microturbine Application and Performance. In Microturbines; Elsevier: Amsterdam, The Netherlands, 2007.

113. Kiciński, J.; Żywica, G. Steam Microturbines in Distributed Cogeneration; Springer: Berlin/Heidelberg, Germany, 2014.

114. Andreas, P. Weiß Volumetric Expander Versus Turbine-Which Is the Better Choice for Small Orc Plants. In Proceedings of the 3rd International Seminar on ORC Power System, Brussels, Belgium, 12-14 October 2015.

115. Takada, H.; Yasue, N.; Oda, Y.; Hachiya, M.; Ichimura, M. The consideration of fundamental specifications and the possibility of maintenance by remote monitoring on Bowman's Micro-gas-turbine CGS “TG80CG”. Proc. Natl. Symp. Power Energy Syst. $2002,8$. [CrossRef]

116. Koepsell, M.; Pfeiffer, J.; Bouvy, C. Einsatz einer Mikro-Gasturbine zur Prozesswärmeerzeugung. Gaswaerme Int. 2004, 53, 32-39.

117. Irshad, M.; Siraj, K.; Raza, R.; Ali, A.; Tiwari, P.; Zhu, B.; Rafique, A.; Ali, A.; Ullah, M.K.; Usman, A. A brief description of high temperature solid oxide fuel cell's operation, materials, design, fabrication technologies and performance. Appl. Sci. 2016,6 , 75. [CrossRef]

118. Dutra, J.C.; Gonzalez-Carmona, M.A.; Lazaro-Alvarado, A.F.; Coronas, A. Modeling of a cogeneration system with a micro gas turbine operating at partial load conditions. J. Sustain. Dev. Energy Water Environ. Syst. 2017, 5. [CrossRef]

119. Matum, T.S.; Nontakaew, U. The performance prediction of a 30-KW multi-fueled micro gas turbine. Int. J. Mech. Prod. Eng. Res. Dev. 2019, 9. [CrossRef]

120. Gimelli, A.; Sannino, R. Thermodynamic model validation of Capstone C30 micro gas turbine. Energy Proced. 2017, 126, 955-962. [CrossRef]

121. Ananienkow, A.G. Energy from microturbines. Energ. Gigawat 2004, 5, 13-15.

122. Hirano, M.Y.; da Silva, C.L. Dairy cattle biogas usage in microturbines for energy generation and thermal exploitation. Eng. Agric. 2018, 38, 526-535. [CrossRef]

123. Amaro, J.; Mendiburu, A.Z.; de Carvalho, J.A. Thermodynamic study of syngas combustion in gas microturbines with regeneration composed with metallic and ceramic materials. Appl. Therm. Eng. 2019, 157. [CrossRef]

124. Mikielewicz, D.; Kosowski, K.; Tucki, K.; Piwowarski, M.; Stępién, R.; Orynycz, O.; Włodarski, W. Influence of different biofuels on the efficiency of gas turbine cycles for prosumer and distributed energy power plants. Energies 2019, 12. [CrossRef]

125. Seo, J.M.; Lim, H.S.; Park, J.Y.; Park, M.R.; Choi, B.S. Development and experimental investigation of a 500-W class ultra-micro gas turbine power generator. Energy 2017, 124. [CrossRef]

126. Capat, R. Experimental Tests of the Operating Conditions of a Micro Gas Turbine Device. J. Energy Power Eng. 2015, 9. [CrossRef]

127. Capata, R. Ultra Micro Gas Turbines. In Efficiency, Performance and Robustness of Gas Turbines; Faculty of Engineering: Rome, Italy, 2012.

128. Capata, R.; Kylykbashi, K.; Calabria, A.; Veroli, M. Di Experimental Tests on a Pre-Heated Combustion Chamber for Ultra Micro Gas Turbine Device: Air/Fuel Ratio Evaluation. Engineering 2016, 8. [CrossRef]

129. Calabria, A.; Capata, R.; Veroli, M.D.; Pepe, G. Testing of the Ultra-Micro Gas Turbine Devices (1-10 kW) for Portable Power Generation at University of Roma 1: First Tests Results. Engineering 2013, 5. [CrossRef]

130. Capata, R.; Saracchini, M. Experimental campaign tests on ultra micro gas turbines, fuel supply comparison and optimization. Energies 2018, 11, 799. [CrossRef]

131. Bo, A.; Giacomazzi, E.; Messina, G.; Di Nardo, A. Analysis of a Fuel Flexible Micro Gas Turbine Combustor Through Numerical Simulations. J. Eng. Gas Turbines Power 2018, 140. [CrossRef]

132. Ruedel, U.; Stefanis, V.; Ramaglia, A.D.; Florjancic, S. Development of the New Ansaldo Energia Gas Turbine Technology Generation; American Society of Mechanical Engineers: New York, NY, USA, 2017; Volume 3.

133. Ramaglia, A.D.; Ruedel, U.; Stefanis, V.; Florjancic, S. Ansaldo Energia Gas Turbine Technology Developments; American Society of Mechanical Engineers: New York, NY, USA, 2018; Volume 3. 
134. Othman, N.F.; Boosroh, M.H. Effect of $\mathrm{H}_{2}$ and $\mathrm{CO}$ contents in syngas during combustion using Micro Gas Turbine. In Proceedings of the IOP Conference Series: Earth and Environmental Science, Tomsk, Russian, 11-16 July 2016; Volume 32.

135. Villarroel-Schneider, J.; Malmquist, A.; Araoz, J.A.; Martí-Herrero, J.; Martin, A. Performance analysis of a small-scale biogasbased trigeneration plant: An absorption refrigeration system integrated to an externally fired microturbine. Energies $2019,12$. [CrossRef]

136. Władysław, K.; Krzysztof, K. Small steam turbines for distributed power generation-technical and economic conditions. Rynek Energ. 2017, 133, 41-46.

137. Orrok, G.A. Small steam turbines. J. Am. Soc. Nav. Eng. 1909, 21, 810-835. [CrossRef]

138. Hennauer, L.; Schmitt, B. New developmental trends for small industrial steam turbines. Brennstoff-Wärme-Kraft 1988, 40, 342-348.

139. Brown, C.O. Small steam turbines Equipment and Design. Ind. Eng. Chem. 1949, 41, 91A-92A. [CrossRef]

140. Żywica, G.; Bagiński, P.; Kiciński, J. Selected operational problems of high-speed rotors supported by gas foil bearings. Tech. Mech. 2017, 37, 339-346. [CrossRef]

141. Kiciński, J. Cogeneration in Small Scale-High Speed Microturbines Dynamic Analysis. In Archives of Acoustics; Institute of Fluid-Flow Machinery, Polish Academy of Sciences: Gdansk, Poland, 2010; Volume 35, pp. 175-182.

142. Zywica, G.; Drewczynski, M.; Kicinski, J.; Rzadkowski, R. Computational modal and strength analysis of the steam microturbine with fluid-film bearings. J. Vib. Eng. Technol. 2014, 2, 543-549.

143. Kicinski, J.; Zywica, G. The numerical analysis of the steam microturbine rotor supported on foil bearings. Adv. Vib. Eng. 2012, $11,113-119$.

144. Kiciński, J.; Żywica, G.; Kiciński, J.; Żywica, G. Introduction to Microturbines Vibration Analysis. In Steam Microturbines in Distributed Cogeneration; Springer: Berlin/Heidelberg, Germany, 2014; pp. 17-37.

145. Kiciński, J. Analysis of the Vibrations of the Low Power ORC Turbines Operating Under Conditions of Strongly Developed Hydrodynamic instability; American Society of Mechanical Engineer: New York, NY, USA, 2018; Volume 1922.

146. Żywica, G.; Kiciński, J.; Kaczmarczyk, T.; Ihnatowicz, E. Design and experimental investigation of the cogenerative domestic micro power plant with ORC system. Mechanik 2015. [CrossRef]

147. Kaczmarczyk, T.Z.; Ihnatowicz, E.; Zywica, G.; Kicinski, J. Experimental investigation of the ORC system in a cogenerative domestic power plant with a scroll expanders. Open Eng. 2015, 5, 411-420. [CrossRef]

148. Kiciński, J. Steam Microturbines-Own Study of the Institute of Fluid Flow Machinery; Institute of Fluid Flow Machinery: Gdansk, Poland, 2014.

149. Wajs, J.; Mikielewicz, D.; Jakubowska, B. Performance of the domestic micro ORC equipped with the shell-and-tube condenser with minichannels. Energy 2018, 157. [CrossRef]

150. Wajs, J.; Mikielewicz, D.; Bajor, M.; Kneba, Z. Experimental investigation of domestic micro-CHP based on the gas boiler fitted with ORC module. Arch. Thermodyn. 2016, 37. [CrossRef]

151. Kosowski, K.; Piwowarski, M.; Stępień, R.; Włodarski, W.; Hirt, Ł. Mikroturbiny. Badania Numeryczne i Eksperymentalne; Fundacja Promocji Przemysłu Okrętowego i Gospodarki Morskiej: Gdańsk, Poland, 2016; ISBN 978-83-60584-60-6.

152. Kosowski, K.; Piwowarski, M.; Stępien, R.; Włodarski, W. Design and investigations of the ethanol microturbine. Arch. Thermodyn. 2018, 39. [CrossRef]

153. Alford, A.; Nichol, P.; Frisby, B. The Development of a Small High Speed Steam Microturbine Generator System. In Proceedings of the IOP Conference Series: Materials Science and Engineering, London, UK, 7-9 September 2015; Volume 90.

154. Kolasiński, P.; Błasiak, P.; Rak, J. Experimental investigation on multi-vane expander operating conditions in domestic CHP ORC system. Energy Proced. 2017, 129, 323-330. [CrossRef]

155. Giampaolo, T. Compressor Handbook Principles and Practice; CRC Press: Boca Raton, FL, USA, 2010; ISBN 0-88173-615-5.

156. Kolasiński, P. Experimental and modelling studies on the possible application of heat storage devices for powering the ORC (organic rankine cycle) systems. Therm. Sci. Eng. Prog. 2020, 19. [CrossRef]

157. Kolasinski, P. Application of the multi-vane expanders in orc systems-A review on the experimental and modeling research activities. Energies 2019, 12, 2975. [CrossRef]

158. Gnutek, Z.; Kolasinski, P. The application of rotary vane expanders in organic rankine cycle systems-Thermodynamic description and experimental results. J. Eng. Gas Turbines Power 2013, 135. [CrossRef]

159. Suankramdee, W.; Thongtip, T.; Aphornratana, S. Development of a sliding vane expander in a micro-scale ORC system for utilizing low-grade heat. Energy Proced. 2017, 138, 817-822. [CrossRef]

160. Materials from Armak Motors Company. Available online: www.armak.co.uk (accessed on 20 December 2020).

161. Termo2Power Company Own Materials. Available online: www.termo2power.com (accessed on 20 December 2020).

162. Norwood, Z.; Kammen, D.; Dibble, R. Testing of the katrix rotary lobe expander for distributed concentrating solar combined heat and power systems. Energy Sci. Eng. 2014, 2, 61-76. [CrossRef]

163. Norwood, Z.; Kammen, D.; Callaway, D.; Dibble, R. A better steam engine: Testing of the Katrix rotary lobe expander for distributed concentrating solar combined heat and power systems. In Proceedings of the World Renewable Energy Forum, WREF 2012, Including World Renewable Energy Congress XII and Colorado Renewable Energy Society (CRES) Annual Conference, Denver, CO, USA, 13-17 May 2012; Volume 1.

164. Wołowicz, M. Przegląd wybranych konstrukcji silników cieplnych małej mocy wykorzystywanych w procesach utylizacji ciepła odpadowego. Rynek Energii 2020, 1, 36-41. 
165. Casari, N.; Fadiga, E.; Pinelli, M.; Suman, A.; Kovacevic, A.; Rane, S.; Ziviani, D. Numerical investigation of oil injection in a Roots blower operated as expander. IOP Conf. Ser. Mat. Sci. Eng. 2019, 604, 12075. [CrossRef]

166. Parthoens, A.; Dumont, O.; Ludovic, G.; Lemort, V. Experimental and Numerical Investigation of a Roots Expander Integrated into an ORC Power System. In Proceedings of the International Compressor Engineering Conference, West Lafayette, IN, USA, 9-12 July 2018.

167. Dumont, O.; Talluri, L.; Fiaschi, D.; Manfrida, G.; Lemort, V. Comparison of a scroll, a screw, a roots, a piston expander and a Tesla turbine for small-scale organic Rankine cycle. In Proceedings of the 5th International Seminar on ORC Power Systems, Athens, Greece, 9-11 September 2019.

168. Ziviani, D.; Gusev, S.; Schuessler, S.; Achaichia, A.; Braun, J.E.; Groll, E.A.; De Paepe, M.; Van Den Broek, M. Employing a Single-Screw Expander in an Organic Rankine Cycle with Liquid Flooded Expansion and Internal Regeneration. Energy Proc. 2017, 129, 379-386. [CrossRef]

169. Ziviani, D.; Suman, A.; Lecompte, S.; De Paepe, M.; Van Den Broek, M.; Spina, P.R.; Pinelli, M.; Venturini, M.; Beyene, A. Comparison of a single-screw and a scroll expander under part-load conditions for low-grade heat recovery ORC systems. Energy Proc. 2014, 61, 117-120. [CrossRef]

170. Wu, Y.T.; Wang, W.; Lei, B.; Zhi, R.P.; Ma, C.F. Developement and Demonstration on Single Screw Expander in Organic Rankine Cycle. In Proceedings of the 5th International Seminar on ORC Power Systems, Athens, Greece, 9-11 September 2019.

171. Wang, J.; Zhang, X.; Zhang, Y.; Zheng, Y.; Wang, W. Experimental study of single screw expander used in lowmedium temperature geothermal power system. Energy Proc. 2014, 61, 854-857. [CrossRef]

172. Ziviani, D.; Bell, I.; Van Den Broek, M.; De Paepe, M. Comprehensive Model of a Single-screw Expander for ORC-Systems. In Proceedings of the International Compressor Engineering Conference, Ghent, Belgium; 2014.

173. Desideri, A.; Van Den Broek, M.; Gusev, S.; Lemort, V.; Quoilin, S. Experimental Campaign and Modeling of a Low-capacity Waste Heat Recovery System Based on a Single Screw Expander. In Proceedings of the 22nd International Compressor Engineering Conference at Purdue, West Lafayette, IA, USA, 14-17 July 2014.

174. Ziviani, D.; Bell, I.; De Paepe, M.; Van Den Broek, M. Mechanistic model of an oil-flooded single-screw expander. In Proceedings of the 23rd International Compressor Engineering Conference at Purdue, West Lafayette, IA, USA, 11-14 July 2016.

175. Lei, B.; Wang, W.; Wu, Y.T.; Ma, C.F.; Wang, J.F.; Zhang, L.; Li, C.; Zhao, Y.K.; Zhi, R.P. Development and experimental study on a single screw expander integrated into an Organic Rankine Cycle. Energy 2016, 116, 43-52. [CrossRef]

176. He, W.; Wu, Y.; Peng, Y.; Zhang, Y.; Ma, C.; Ma, G. Influence of intake pressure on the performance of single screw expander working with compressed air. Appl. Therm. Eng. 2013, 51, 662-669. [CrossRef]

177. Zhang, X.; Zhang, Y.; Cao, M.; Wang, J.; Wu, Y.; Ma, C. Working fluid selection for organic Rankine cycle using single-screw expander. Energies 2019, 12, 3197. [CrossRef]

178. Bianchi, M.; Branchini, L.; Casari, N.; De Pascale, A.; Melino, F.; Ottaviano, S.; Pinelli, M.; Spina, P.R.; Suman, A. Experimental analysis of a micro-ORC driven by piston expander for low-grade heat recovery. Appl. Therm. Eng. 2019, 148, 1278-1291. [CrossRef]

179. Bianchi, M.; Branchini, L.; De Pascale, A.; Melino, F.; Ottaviano, S.; Peretto, A.; Torricelli, N. Performance prediction of a reciprocating piston expander with semi-empirical models. Energy Proced. 2019, 158, 1737-1743. [CrossRef]

180. Ancona, M.A.; Bianchi, M.; Branchini, L.; De Pascale, A.; Melino, F.; Orlandini, V.; Ottaviano, S.; Peretto, A.; Pinelli, M.; Spina, P.R.; et al. A Micro-ORC Energy System: Preliminary Performance and Test Bench Development. Energy Proced. 2016, 101, 814-821. [CrossRef]

181. Bouvier, J.L.; Lemort, V.; Michaux, G.; Salagnac, P.; Kientz, T. Experimental study of an oil-free steam piston expander for micro-combined heat and power systems. Appl. Energy 2016, 169, 788-798. [CrossRef]

182. Guarracino, I.; Mathie, R.; Taleb, A.; Markides, C. An Experimental Analysis Of A Low-Loss Reciprocating Piston Expander For Use In Small-Scale Organic Rankine Cycles. In Proceedings of the 2nd International Seminar on ORC Power Systems, Rotterdam, The Netherlands, 7-8 October 2013.

183. Markides, C.; Guarracino, I.; Mathie, R. Reciprocating Piston Expanders for Small-Scale ORC Systems. In Proceedings of the 2nd International Seminar on ORC Power Systems, Rotterdam, The Netherlands, 7-8 October 2013.

184. Glavatskaya, Y.; Podevin, P.; Lemort, V.; Shonda, O.; Descombes, G. Reciprocating expander for an exhaust heat recovery rankine cycle for a passenger car application. Energies 2012, 5, 1751-1765. [CrossRef]

185. Kim, Y.M.; Shin, D.G.; Kim, C.G. Optimization of design pressure ratio of positive displacement expander for vehicle engine waste heat recovery. Energies 2014, 7, 6105-6117. [CrossRef]

186. Galindo, J.; Ruiz, S.; Dolz, V.; Royo-Pascual, L.; Haller, R.; Nicolas, B.; Glavatskaya, Y. Experimental and thermodynamic analysis of a bottoming Organic Rankine Cycle (ORC) of gasoline engine using swash-plate expander. Energy Convers. Manag. 2015, 103, 519-532. [CrossRef]

187. Oudkerk, J.F.; Dickes, R.; Dumont, O.; Lemort, V. Experimental performance of a piston expander in a small- scale organic Rankine cycle. IOP Conf. Ser. Mat. Sci. Eng. 2015, 90, 012066. [CrossRef]

188. Hou, X.; Zhang, H.; Yu, F.; Liu, H.; Yang, F.; Xu, Y.; Tian, Y.; Li, G. Free piston expander-linear generator used for organic Rankine cycle waste heat recovery system. Appl. Energy 2017, 208, 1297-1307. [CrossRef]

189. Hou, X.; Zhang, H.; Xu, Y.; Yu, F.; Zhao, T.; Tian, Y.; Yang, Y.; Zhao, R. External load resistance effect on the free piston expander-linear generator for organic Rankine cycle waste heat recovery system. Appl. Energy 2018, 212, 1252-1261. [CrossRef] 
190. Li, G.; Zhang, H.; Yang, F.; Song, S.; Chang, Y.; Yu, F.; Wang, J.; Yao, B. Preliminary development of a free piston expander-linear generator for small-scale Organic Rankine Cycle (ORC) waste heat recovery system. Energies 2016, 9, 300. [CrossRef]

191. Antonelli, M.; Francesconi, M.; Baccioli, A.; Caposciutti, G. Experimental Results of a Wankel-type Expander Fuelled by Compressed Air and Saturated Steam. Energy Proced. 2017, 105, 2929-2934. [CrossRef]

192. Francesconi, M.; Caposciutti, G.; Antonelli, M. An experimental and numerical analysis of the performances of a Wankel steam expander. Energy 2018, 164, 615-626. [CrossRef]

193. Badr, O.; Naik, S.; O'Callaghan, P.W.; Probert, S.D. Rotary Wankel engines as expansion devices in steam Rankine-cycle engines. Appl. Energy 1991, 39, 59-76. [CrossRef]

194. Badr, O.; Naik, S.; O'Callaghan, P.W.; Probert, S.D. Wankel engines as steam expanders: Design considerations. Appl. Energy 1991, 40, 157-170. [CrossRef]

195. Badr, O.; Naik, S.; O'Callaghan, P.W.; Probert, S.D. Expansion machine for a low power-output steam Rankine-cycle engine. Appl. Energy 1991, 39, 93-116. [CrossRef]

196. Tozer, G.; Ga, J.; Al-Dadah, R.; Mahmoud, S. Development of Efficient Static Shaft Wankel Expander for Organic Rankine Cycles. In Proceedings of the 5th International Seminar on ORC Power Systems, Athens, Greece, 9-11 September 2019.

197. Park, K.-T.; Kim, Y.-H.; Kim, H.-J. Design and performance analysis of a gerotor expander for power generation from waste heat. J. Korea Soc. Power Syst. Eng. 2016, 20, 17-25. [CrossRef]

198. Mathias, J.A.; Johnston, J.R.; Cao, J.; Priedeman, D.K.; Christensen, R.N. Experimental testing of gerotor and scroll expanders used in, and energetic and exergetic modeling of, an organic Rankine cycle. J. Energy Resour. Technol. Trans. ASME 2009, 131, 0122011-0122019. [CrossRef]

199. Yamada, N.; Tominaga, Y.; Yoshida, T. Demonstration of 10-Wp micro organic Rankine cycle generator for low-grade heat recovery. Energy 2014, 78, 806-813. [CrossRef]

200. Webb, K.R. Sir William Robert Grove (1811-1896) and the origins of the fuel cell. J. R. Inst. Chem. 1961, 85, $291-295$.

201. William Robert Grove. Phys. Today, 11 July 2016. [CrossRef]

202. Gray, A.A. Sir William Robert Grove. Nature 1896, 54. [CrossRef]

203. Wisniak, J. Historical Notes: Electrochemistry and Fuel Cells: The Contribution of William Robert Grove. Indian J. Hist. Sci. 2015, 50. [CrossRef]

204. Appleby, A.J. From Sir William Grove to today: Fuel cells and the future. J. Power Source 1990, 29. [CrossRef]

205. Haseli, Y. Maximum conversion efficiency of hydrogen fuel cells. Int. J. Hydrogen Energy 2018, 43, 9015-9021. [CrossRef]

206. Giorgi, L. Fuel Cells: Technologies and Applications. Open Fuel Cells J. 2013, 6. [CrossRef]

207. Carrette, L.; Friedrich, K.A.; Stimming, U. Fuel cells: Principles, types, fuels, and applications. ChemPhysChem 2000, 1, 162-193. [CrossRef]

208. Lucia, U. Overview on fuel cells. Renew. Sustain. Energy Rev. 2014, 30, 164-169. [CrossRef]

209. Coralli, A.; Sarruf, B.J.M.; De Miranda, P.E.V.; Osmieri, L.; Specchia, S.; Minh, N.Q. Fuel Cells. In Science and Engineering of Hydrogen-Based Energy Technologies: Hydrogen Production and Practical Applications in Energy Generation; Academic Press: Cambrigde, MA, USA, 2018; pp. 39-122. ISBN 9780128142516.

210. Kunze-Liebhäuser, J.; Paschos, O.; Pethaiah, S.S.; Stimming, U. Fuel Cell Comparison to Alternate Technologies. In Fuel Cells and Hydrogen Production; Springer: New York, NY, USA, 2019; pp. 11-25.

211. Kwan, T.H.; Wu, X.; Yao, Q. Performance comparison of several heat pump technologies for fuel cell micro-CHP integration using a multi-objective optimisation approach. Appl. Therm. Eng. 2019, 160. [CrossRef]

212. Kunze-Liebhäuser, J.; Paschos, O.; Pethaiah, S.S.; Stimming, U. Fuel Cell Comparison to Alternate Technologies. In Encyclopedia of Sustainability Science and Technology; Springer: New York, NY, USA, 2017; pp. 1-16.

213. Milewski, J.; Wolowicz, M.; Badyda, K.; Misztal, Z. Operational characteristics of 36kW PEMFC-CHP unit. Rynek Energ. 2011, 92, 150-156.

214. Milewski, J.; Wolowicz, M.; Badyda, K.; Misztal, Z. 36 kW Polymer Exchange Membrane Fuel Cell as Combined Heat and Power Unit. ECS Trans. 2019, 42, 75-87. [CrossRef]

215. Calì, M.; Santarelli, M.G.L.; Leone, P. Design of experiments for fitting regression models on the tubular SOFC CHP $100 \mathrm{kWe:}$ Screening test, response surface analysis and optimization. Int. J. Hydrog. Energy 2007, 32, 343-358. [CrossRef]

216. Cinti, G.; Bidini, G.; Hemmes, K. Comparison of the solid oxide fuel cell system for micro CHP using natural gas with a system using a mixture of natural gas and hydrogen. Appl. Energy 2019, 238, 69-77. [CrossRef]

217. Naimaster, E.J.; Sleiti, A.K. Potential of SOFC CHP systems for energy-efficient commercial buildings. Energy Build. 2013, 61, 153-160. [CrossRef]

218. Suzuki, M.; Iwata, S.; Higaki, K.; Inoue, S.; Shigehisa, T.; Miyachi, I.; Nakabayashi, H.; Shimazu, K. Development and Field Test Results of Residential SOFC CHP System. ECS Trans. 2019, 25, 143-147. [CrossRef]

219. Palomba, V.; Ferraro, M.; Frazzica, A.; Vasta, S.; Sergi, F.; Antonucci, V. Experimental and numerical analysis of a SOFC-CHP system with adsorption and hybrid chillers for telecommunication applications. Appl. Energy 2018, 216, 620-633. [CrossRef]

220. Yang, C.H.; Chang, S.C.; Chan, Y.H.; Chang, W.S. A dynamic analysis of the multi-stack SOFC-ChP system for power modulation. Energies 2019, 12, 3686. [CrossRef]

221. Heatstack to cut cost of components in fuel cell mCHP. Fuel Cells Bull. 2016, 12. [CrossRef] 
222. Sghaier, S.F.; Khir, T.; Ben Brahim, A. Energetic and exergetic parametric study of a SOFC-GT hybrid power plant. Int. J. Hydrog. Energy 2018, 43, 3542-3554. [CrossRef]

223. Badur, J.; Lemański, M.; Kowalczyk, T.; Ziółkowski, P.; Kornet, S. Zero-dimensional robust model of an SOFC with internal reforming for hybrid energy cycles. Energy 2018, 158, 128-138. [CrossRef]

224. Chen, J.; Liang, M.; Zhang, H.; Weng, S. Study on control strategy for a SOFC-GT hybrid system with anode and cathode recirculation loops. Int. J. Hydrog. Energy 2017, 42, 29422-29432. [CrossRef]

225. Meng, Q.; Han, J.; Kong, L.; Liu, H.; Zhang, T.; Yu, Z. Thermodynamic analysis of combined power generation system based on SOFC/GT and transcritical carbon dioxide cycle. Int. J. Hydrog. Energy 2017, 42, 4673-4678. [CrossRef]

226. Liu, Y.; Han, J.; You, H. Performance analysis of a CCHP system based on SOFC/GT/CO2 cycle and ORC with LNG cold energy utilization. Int. J. Hydrog. Energy 2019, 44, 29700-29710. [CrossRef]

227. Huang, Y.; Turan, A. Fuel sensitivity and parametric optimization of SOFC-GT hybrid system operational characteristics. Therm. Sci. Eng. Prog. 2019, 14. [CrossRef]

228. Barelli, L.; Bidini, G.; Ottaviano, A. Integration of SOFC/GT hybrid systems in Micro-Grids. Energy 2017, 118, 716-728. [CrossRef]

229. Harun, N.F.; Tucker, D.; Adams, T.A. Technical challenges in operating an SOFC in fuel flexible gas turbine hybrid systems: Coupling effects of cathode air mass flow. Appl. Energy 2017, 190, 852-867. [CrossRef]

230. Tompsett, G.A.; Finnerty, C.; Kendall, K.; Sammes, N.M. Integrated Catalytic Burner/Micro-SOFC Design and Applications. Electrochemistry 2000, 68, 519-521. [CrossRef]

231. Wang, J.; Yan, Z.; Ma, S.; Dai, Y. Thermodynamic analysis of an integrated power generation system driven by solid oxide fuel cell. Int. J. Hydrog. Energy 2012, 37, 2535-2545. [CrossRef]

232. Pianko-Oprych, P.; Jaworski, Z. Numerical investigation of a novel burner to combust anode exhaust gases of SOFC stacks. Pol. J. Chem. Technol. 2017, 19, 20-26. [CrossRef]

233. Zeng, H.; Wang, Y.; Shi, Y.; Cai, N. Biogas-fueled flame fuel cell for micro-combined heat and power system. Energy Convers. Manag. 2017, 148, 701-707. [CrossRef]

234. Milcarek, R.J.; Garrett, M.J.; Ahn, J. Micro-tubular flame-assisted fuel cells. J. Fluid Sci. Technol. 2017, 12. [CrossRef]

235. Milcarek, R.J.; Wang, K.; Falkenstein-Smith, R.L.; Ahn, J. Micro-tubular flame-assisted fuel cells for micro-combined heat and power systems. J. Power Source 2016, 306, 148-151. [CrossRef] 